CLÁUDIO RODRIGUES REZENDE COSTA

\title{
AVALIAÇÃO DOS EFEITOS DA EUGENIA DYSENTERICA EM CULTURA PRIMÁRIA DE CÉLULAS DE MUCOSA GENGIVAL E LIGAMENTO PERIODONTAL
}


UNIVERSIDADE DE BRASÍLIA

FACULDADE DE CIÊNCIAS DA SAÚDE

PROGRAMA DE PÓS-GRADUAÇÃo EM CIÊNCIAS DA SAÚDE

CLÁUDIO RODRIGUES REZENDE COSTA

\section{AVALIAÇÃO DOS EFEITOS DA EUGENIA DYSENTERICA EM CULTURA PRIMÁRIA DE CÉLULAS DE MUCOSA GENGIVAL E LIGAMENTO PERIODONTAL}

Dissertação apresentada como requisito parcial para obtenção do título de Mestre em Ciências da Saúde pelo programa de Pós-Graduação em Ciências da Saúde da Universidade de Brasília.

Orientadora: Prof. Dra. Eliete Neves da Silva Guerra

Coorientadora: Dra. Bruna Rabelo Amorim

Brasília 


\title{
AVALIAÇÃO DOS EFEITOS DA EUGENIA DYSENTERICA EM CULTURA PRIMÁRIA DE CÉLULAS DE MUCOSA GENGIVAL E LIGAMENTO PERIODONTAL
}

\begin{abstract}
Dissertação apresentada como requisito parcial para obtenção do título de Mestre em Ciências da Saúde pelo programa de Pós-Graduação em Ciências da Saúde da Universidade de Brasília.
\end{abstract}

Aprovado em 01 de Julho de 2016.

\section{BANCA EXAMINADORA}

Prof. Dr. Eliete Neves da Silva Guerra (presidente) Universidade de Brasília (UnB)

Prof. Dr. Pérola de Oliveira Magalhães

Universidade de Brasília (UnB)

Prof. Dr. Paula Dechichi

Universidade Federal de Uberlândia (UFU) 
Dedico este trabalho à Deus, por ter me dado a oportunidade de viver com saúde e inteligência para hoje celebrar a realização de mais um grande sonho... 


\section{AGRADECIMENTOS}

À professora Eliete Neves da Silva Guerra, por seu carinho e acolhimento que desde o início dos meus estudos mostrou-me a empolgação de ser um pesquisador. Obrigado por ter acreditado em mim e ter me ensinado tanto em tão pouco tempo. Agradeço por seu exemplo dentro da Universidade, desde a dedicação com o mais alto grau de responsabilidade administrativa, até o mais simples cuidado com nós alunos de pós-graduação.

À minha coorientadora Bruna Rabelo Amorim, que me acompanhou durante todo o percurso de aprendizado durante o mestrado. Agradeço pelos ensinamentos de todos os experimentos que no início tão desconhecido e assustador, passou a ser prazeroso e gratificante. Obrigado pela infinita paciência que teve comigo durante esse período. Pode ter certeza de que, de tudo o que eu conquistei contigo, o melhor foi a amizade que criamos nesses anos.

Aos meus pais, Marcelo e Vanuza, e meu irmão Gustavo que, mesmo distantes fisicamente, estão sempre me acompanhando e apoiando meus estudos e trabalho. Obrigado por mais uma vez acreditarem em meus sonhos, e me apoiarem no meu crescimento. Amo vocês!

Às minhas amigas Karine, Rose e Dani por estarem ao meu lado nessa etapa tão importante em minha vida. Nesse trabalho tem um pouco de vocês e sem vocês eu jamais teria ao menos tido coragem de iniciar.

À minha amiga Ludmila Madeira Cardoso Pavan agradeço de todo coração por ter me ajudado a dar os primeiros passos na pós-graduação. Não há como não aprender convivendo com você, seja na instalação de um implante, seja na leitura de um artigo, seja na forma de viver a vida. Obrigado por ter feito parte de mim.

À professora Ana Carolina Acevedo por sempre guiar meus pensamentos me ensinando com tanta simplicidade. Em alguns poucos minutos fui capaz de aprender inúmeros detalhes que mudaram minha percepção de biologia molecular e me fizeram, inclusive, conseguir desenvolver uma revisão sistemática. 
À professora Graziela De Luca Canto pelo apoio e orientação para realizar minha primeira revisão sistemática, trabalho que nos foi base para concretizar meu trabalho.

À professora Pérola Magalhães e à doutoranda Sandra Márcia por apoiar nossos estudos com os extratos de plantas e com a disponibilidade de auxiliar nossos experimentos.

À Professora Paula Dechichi pela inspiração desde a época da graduação. Agradeço por aceitar o convite em participar da minha defesa, e por ter me incentivado e ajudado a iniciar os meus estudos e interesse pela área de pesquisa, principalmente pela área básica. Sempre a tenho como exemplo, e quando tiver a oportunidade de ser um professor universitário serei inspirado na sua calma e inteligência.

Ao Guilherme por ter me apoiado o tempo todo e acreditado em meu potencial, sem contar com a paciência de me ver os finais de semana ora dia todo dentro do laboratório, ora escondido atrás de artigos dentro de casa. Obrigado pelo carinho.

Às minhas amigas de pós-graduação Ana Luíza, Ana Elizia e Carol, meu muito obrigado por sempre estarem comigo me ouvindo e ensinando. Foi importante demais vocês ao meu lado. Agradeço pelo acolhimento e por se tornarem pessoas tão especiais para mim.

Aos amigos do laboratório de Histopatologia Bucal da UnB, agradeço pelo companheirismo e pelos socorros prestados durante minha caminhada de experimentos. Agradeço pelos estudos e pelas boas risadas que nos descontraiam em momentos exaustivos dos estudos.

Ao projeto Centro-Oeste, intitulado "Bioprospecção de plantas do Cerrado e Pantanal para o desenvolvimento de novos biofármacos para 0 tratamento do câncer", edital MCT/CNPq/FNDCT/FAPs/MEC/CAPES/PRO-CENTRO-OESTE N ${ }^{\circ}$ 031/2010, contemplado por fomento junto ao CNPq. 
Ao Exército Brasileiro, em especial aos meus amigos de cirurgia do Hospital Militar de Área de Brasília (HMAB). Agradeço pelo apoio dado para que esse trabalho fosse realizado.

Aos pacientes participantes dessa pesquisa pela confiança e disponibilidade para nos ajudar na realização do projeto.

Ao Programa de Pós-graduação em Ciências da Saúde da Faculdade de Medicina e Ciências da Saúde da Universidade de Brasília.

À Universidade de Brasília pela oportunidade de me qualificar com conhecimentos muito além dos resultados adquiridos em meu projeto de pesquisa. 
"Um cientista em seu laboratório não é um mero técnico: é também uma criança que confronta os fenômenos naturais que o impressionam como faziam os contos de fada."

(Marie Curie) 


\section{RESUMO}

Pesquisas recentes têm mostrado compostos bioativos como responsáveis por efeitos farmacológicos de plantas. Dentre muitas, a Eugenia dysenterica tem apresentado efeitos antioxidante, antifúngico, antidiarreico, atividade inibitória sobre a enzima tirosinase e potencial efeito para tratamentos gástricos. Este estudo teve como objetivo avaliar os efeitos da Eugenia dysenterica em cultura primária de células de mucosa gengival e ligamento periodontal. Foi estabelecido cultura primária das células e ensaio de MTT foi realizado em linhagens celulares de mucosa gengival e ligamento periodontal humanos, testando nove concentrações de fração acetônica do extrato de folhas de Eugenia dysenterica. As concentrações de 41,5 e $8,3 \mu \mathrm{g} / \mathrm{mL}$ apresentaram menor citotoxicidade em células gengivais $(p<0,05)$, porém foram citotóxicas para as linhagens do ligamento periodontal. $\mathrm{Na}$ concentração de $83 \mu \mathrm{g} / \mathrm{mL}$ a fração acetônica de folhas do extrato de Eugenia dysenterica não apresentou ação antifúngica para Candida albicans. Como controle positivo foi utilizado o digluconato de clorexidina nas concentrações de $0,12 \%$ e $0,2 \%$. O digluconato de clorexidina apresentou intensa citotoxicidade para as células gengivais quando comparadas ao extrato de Eugenia dysenterica $(\mathrm{p}<0,05)$. $\mathrm{O}$ ensaio de ferida com as células gengivais mostrou que não houve indução do fechamento da ferida pós tratamento com Eugenia dysenterica, assim como também diminuiu a motilidade das células após o tratamento. $O$ ensaio de mineralização foi evidenciado com vermelho de alizarina $S$ e Von Kossa para as células de ligamento periodontal tratadas com o extrato de Eugenia dysenterica e estas não apresentaram diferenciação e capacidade de mineralização. Frente aos resultados, concluiu-se que o extrato de Eugenia dysenterica não se apresentou citotóxico para as células gengivais, porém nas concentrações utilizadas inibiu a proliferação e motilidade de células gengivais, alterou a morfologia celular e não apresentou efeito osteogênico para as células do ligamento periodontal.

Palavras-chave: Eugenia dysenterica; cultura primária de células; mucosa gengival; ligamento periodontal. 


\section{ABSTRACT}

Recent research has determined bioactive compounds as responsible for pharmacological effects of plants. Among all, the Eugenia dysenterica has shown antioxidant, anti-fungal and anti-diarrheal effects, inhibitory activity on the enzyme tyrosinase and potential effect on gastric treatments. This study aimed to evaluate the effects of Eugenia dysenterica in primary culture of gingival mucosa and periodontal ligament cells. First, the primary culture of cells were established and MTT assay was performed both cell lines. Nine concentrations of Eugenia dysenterica extract were used. The concentrations of 41.5 and $83 \mu \mathrm{g} / \mathrm{mL}$ showed less cytotoxicity in gingival cells $(p<0.05)$, but were cytotoxic to the periodontal ligament samples. The concentration of $83 \mu \mathrm{g} / \mathrm{mL}$ Eugenia dysenterica extract had no antifungal effects on Candida albicans. As a positive control, chlorhexidine digluconate was used at concentrations of $0.12 \%$ and $0.2 \%$. Chlorhexidine was severe cytotoxic to gingival cells when compared to the Eugenia dysenterica extract $(p<0.05)$. The healing assay with gingival and periodontal ligament cells showed no induction of wound closure after treatment with Eugenia dysenterica, as well as decreased the motility of the cells after treatment. Alizarin Red $S$ and Von Kossa staining were used to evidence the mineralization of periodontal ligament cells treated with the extract Eugenia dysenterica but there was no or mineral deposits on these cells after the treatment. Based on the results, it was concluded that the Eugenia dysenterica extract were not cytotoxic to gingival cells. However, the concentrations used inhibited proliferation and motility of cells, modified cellular morphology and did not have osteogenic effect for periodontal ligament cells.

Key Worlds: Eugenia dysenterica; primary culture of cells; gingival mucosa; periodontal ligament. 


\section{LISTA DE FIGURAS}

Figura 1. Esquema ilustrativo do dente e seus tecidos de suporte periodontal. $\mathrm{A}: \mathrm{Na}$ figura observamos o dente no alvéolo dentário. O cemento (amarelo) revestindo a raiz do dente e a disposição das fibras do ligamento periodontal (vermelho) entre o cemento e o osso alveolar. B: Imagem histológica de corte axial da raiz dentária e seus tecidos de suporte. Fonte: Próprio autor.

Figura 2. Eugenia dysenterica: Folhas e árvore da cagaiteira jovem. Planta localizada na cidade de Uberlândia, Minas Gerais, Brasil. Fonte: próprio autor. ......26

Figura 3. Etapas para cultivo celular pela técnica de explant. A: Lavagem do fragmento gengival com PBS. B e C: Obtenção dos fragmentos gengivais por meio de secção com lâmina de bisturi. D: Fragmentos dispostos em pratos de cultura de $35 \mathrm{~mm}$. E: Fragmentos fixados com lamínulas de vidro estéreis. F: Adição de $2 \mathrm{~mL}$ de meio de cultura.

Figura 4. Etapas para cultivo celular pela técnica de digestão enzimática. A: Lavagem do dente com PBS. B: Remoção do ligamento periodontal com ajuda de uma cureta. C: Fragmentos depositados em um prato de $35 \mathrm{~mm}$. D: Adição de $3 \mathrm{~mL}$ de solução enzimática de colagenase/dispase. E: Solução com tecido sendo passada pelo separador celular. F: Prato de cultura celular com meio e células. .....34

Figura 5. Avaliação do efeito citotóxico de nove concentrações de fração acetônica de Eugenia dysenterica em células de mucosa gengival em 24 horas. CTRL = controle.

Figura 6. Avaliação do efeito citotóxico de nove concentrações de fração acetônica de Eugenia dysenterica em células de mucosa gengival em 48 horas. CTRL = controle. ( ${ }^{*} p<0,05$ versus controle; teste One-way ANOVA, Postest Turkey's)

Figura 7. Avaliação do efeito citotóxico de nove concentrações de fração acetônica de Eugenia dysenterica em células de mucosa gengival em 72 horas. CTRL = controle. 
Figura 8. Efeito citotóxico de FAED e $\mathrm{CHX}$ em células de mucosa gengival. CTRL: controle DMEM 2\%; 1: FAED 41,5 $\mathrm{g} / \mathrm{mL}$ + DMEM 2\%; 2: CHX 0,12\% + DMEM 2\%; 3: CHX 0,2\% + DMEM 2\%; 4: FAED 41,5 $\mu \mathrm{g} / \mathrm{mL}+$ CHX 0,12\% + DMEM 2\%; 5: FAED $41,5 \mu \mathrm{g} / \mathrm{mL}+\mathrm{CHX} 0,2 \%+\operatorname{DMEM} 2 \%$. ( ${ }^{*} \mathrm{p}<0,05$ versus controle; teste One-way

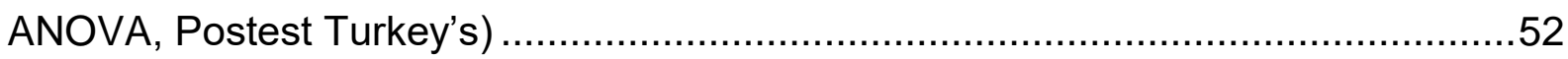

Figura 9. Avaliação do efeito citotóxico de FAED $83 \mu \mathrm{g} / \mathrm{mL}$ em 24 horas. $\mathrm{CTRL}=$ Controle; FAED = Fração acetônica de Eugenia dysenterica à $83 \mu \mathrm{g} / \mathrm{mL}$. 53

Figura 10. Avaliação do efeito citotóxico de FAED em células do ligamento periodontal. $C T R L=$ controle $\left({ }^{*} p<0,05\right.$ versus controle; teste One-way ANOVA, Postest Turkey's). .54

Figura 11. Morfologia de células de mucosa gengival tratadas com FAED na concentração de $41,5 \mu \mathrm{g} / \mathrm{mL}$. A, C e E: células do grupo controle com aspecto morfológico normal. B, D e F: células tratadas com a FAED com alterações morfológicas comparadas ao grupo controle.

Figura 12. Efeito de $41,5 \mu \mathrm{g} / \mathrm{mL}$ da fração acetônica de extrato de Eugenia dysenterica em células de mucosa gengival após 48 horas. A: Células do grupo controle sem alterações morfológicas. B: Células de mucosa gengival tratadas com a FAED. Observa-se a retração celular, perda da adesão celular e presença de vacúolos.

Figura 13. Morfologia das células de ligamento periodontal tratadas com FAED $(83 \mu \mathrm{g} / \mathrm{mL})$. A, C, E, G, I: grupo controle com aspecto morfológico normal; B, D, F, H, J: grupo tratado com a FAED, observar a perda de ligações intercelulares e células alterando o aspecto fusiforme para uma morfologia celular esférica.

Figura 14. Avaliação do fechamento de lesão em monocamada de células gengivais tratamentas com FAED. A, C, E, G, I: Células do grupo controle, tratadas com DMEM 2\%FBS; observar fechamento total da ferida em 48 horas. B, D, F, H, J: Células do grupo FAED, tratadas com DMEM 2\%FBS e 41,5 $\mu \mathrm{g} / \mathrm{mL}$ de FAED, não apresentando fechamento da ferida comparado ao grupo controle. .59 
Figura 15. Cálculo do tamanho da área da ferida expresso em porcentagem. CTRL: Grupo controle; FAED: Grupo tratado com $41,5 \mu \mathrm{g} / \mathrm{mL}$ de fração acetônica do extrato de Eugenia dysenterica.

Figura 16. Percentual de células de mucosa gengival que migraram pela membrana Transwell, tratadas ou não com 41,5 $\mathrm{g} / \mathrm{mL}$ de FAED. CTRL: Grupo controle.

Figura 17. Avaliação colorimétrica por Vermelho de Alizarina $S$ da FAED na mineralização do ligamento periodontal em 14 dias. $A=$ Controle ( $\alpha$-MEM 10\%); B = FAED ( $\alpha$-MEM $10 \%+$ FAED $83 \mu \mathrm{g} / \mathrm{mL}) ; C=$ FAED+MI $(\alpha-M E M 10 \%+$ FAED $83 \mu \mathrm{g} / \mathrm{mL}+\mathrm{AA}+\mathrm{BG}+\mathrm{DEX})) ; \mathrm{D}=\mathrm{MI}(\alpha-M E M 10 \%+A A+B G+D E X)$.

Figura 18. Avaliação colorimétrica por Vermelho de Alizarina $S$ da FAED na mineralização do ligamento periodontal em 21 dias. $A=$ Controle; $B=F A E D ; C=$ FAED+MI; D = MI. 63

Figura 19. Avaliação colorimétrica por Von Kossa do efeito de FAED na mineralização do ligamento periodontal em 21 dias. $\mathrm{A}=$ Controle; $\mathrm{B}=\mathrm{FAED} ; \mathrm{C}=\mathrm{Ml}$; $\mathrm{D}=\mathrm{FAED}+\mathrm{Ml}$.

Figura 20. A: Cepas de Candida albicans 40277 não foram sensíveis ao digluconato de clorexidina a 0,2 e $0,12 \%$ ou em combinação com a FAED pelo método de difusão em disco. B: Controle negativo e positivo fluconazol .65

Figura 21. Concentração inibitória mínima do digluconato de clorexidina 0,2 e 0,12\% sozinho ou em combinação contra Candida albicans 40277 pelo método de microdiluição. .66

Figura 22. Concentração inibitória mínima do fluconazol para Candida albicans. ....66 


\section{LISTA DE TABELAS}

Tabela 1. Avaliação da atividade citotóxica de nove concentrações de fração acetônica de extrato de Eugenia dysenterica em linhagem celular de mucosa gengival.

Tabela 2. Avaliação da atividade citotóxica de FAED à $41,5 \mu \mathrm{g} / \mathrm{mL}$ e digluconato de clorexidina (CHX) em células de mucosa gengival. .51 


\section{LISTA DE ABREVIATURAS E SIGLAS}
AA Ácido ascórbico
ATCC American Type Culture Collection
BG Beta-glicerofosfato
$\mathrm{CHX} \quad$ Digluconato de clorexidina
CIM Concentração Inibitória Mínima
CTRL Controle
DEX Dexametasona
DMEM Dulbelcco's Modified Eagle's Medium
FAED Fração acetônica de extrato aquoso de folhas de Eugenia dysenterica
FBS Soro fetal bovino
HIV Vírus da imunodeficiência humana
MI Meio indutor
NCCLS National Committee for Clinical Laboratory Standards
PBS Solução tampão de fosfato
SUS Sistema Único de Saúde
UFC Unidade Formadora de Colônia
a-MEM Minimum Essential Medium Eagle modificação alfa 


\section{SUMÁRIO}

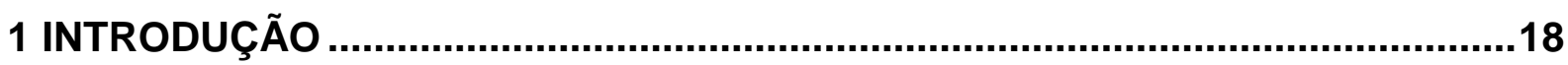

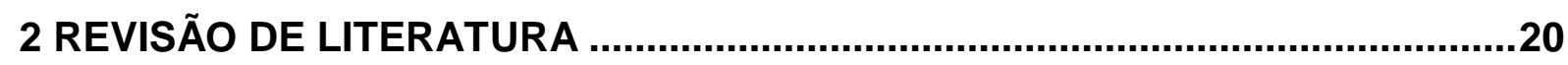

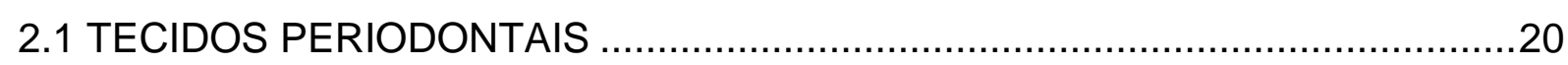

2.2 PLANTAS MEDICINAIS E A UTILIZAÇÃO EM ODONTOLOGIA ......................23

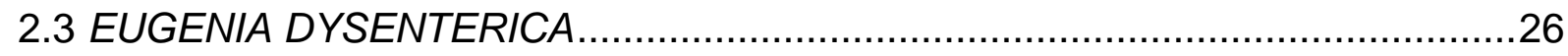

2.4 EUGENIA DYSENTERICA E TECIDOS PERIODONTAIS..............................29

3 OBJETIVOS

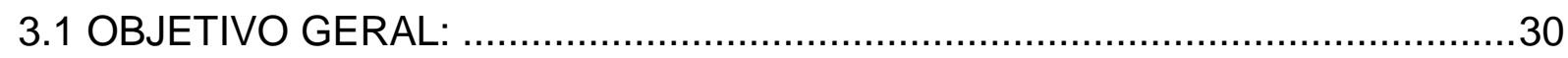

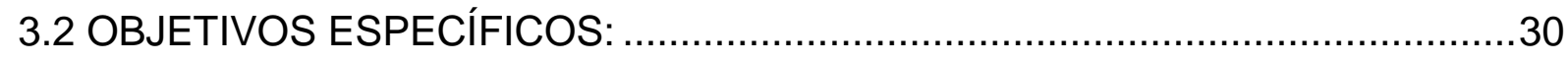

3.2.1 Estabelecer cultura primária de células da mucosa gengival e do ligamento periodontal de dentes com indicação de exodontia; ;...............................................30

3.2.2 Avaliar a viabilidade celular da cultura primária estabelecida dos tecidos dentários, após tratamento com a fração acetônica do extrato aquoso de folhas de Eugenia dysenterica (FAED); ...........................................................................

3.2.3 Estabelecer as concentrações ideais da FAED para tratamento dos tecidos de musosa gengival e ligamento periodontal; 30

3.2.4 Analisar a morfologia celular da cultura primária de células dos tecidos após tratamento com FAED; 
3.2.5 Avaliar o potencial de proliferação e migração de células de mucosa gengival após tratamento com FAED;

3.2.6 Investigar o papel da FAED na mineralização e diferenciação osteogênica das células do ligamento periodontal.

3.2.7 Avaliar e comparar a atividade antimicrobiana do digluconato de clorexidina combinado com a FAED.

4 METODOLOGIA

4.1 OBTENÇÃO DE MUCOSA GENGIVAL E LIGAMENTO PERIODONTAL HUMANOS E ESTABELECIMENTO DE CULTURA PRIMÁRIA DE CÉLULAS ........31

4.2 OBTENÇÃO DO EXTRATO DE EUGENIA DYSENTERICA. .35

4.3 TESTE DE CITOTOXICIDADE CELULAR. .36

4.4 ANÁLISE DE MORFOLOGIA CELULAR. .38

4.5 TESTE DE FECHAMENTO DE LESÃO E MIGRAÇÃO CELULAR .39

4.5.1 Teste de fechamento de lesão em monocamada (Scratch assay) .39

4.5.2 Ensaio de Migração (Transwell Migration Assay) 40

4.6 ENSAIO DE DIFERENCIAÇÃO OSTEOGÊNICA

4.6.1 Coloração por Vermelho de Alizarina S 41

4.6.2 Coloração por Von Kossa .42

4.7 ANÁLISE DA ATIVIDADE ANTIMICROBIANA DA EUGENIA DYSENTERICA ..43

4.7.1 Condições de cultura e padronização .43

4.7.2 Método de Difusão em Disco .44 
5 RESULTADOS.

5.1 CITOTOXICIDADE DO EXTRATO DE EUGENIA DYSENTERICA EM CÉLULAS DE MUCOSA GENGIVAL

5.2 AVALIAÇÃO DA CITOTOXICIDADE INDUZIDA PELA FRAÇÃO ACETÔNICA COMPARADA COM O DIGLUCONATO DE CLOREXIDINA NAS LINHAGENS DE MUCOSA GENGIVAL.

5.3 CITOTOXICIDADE DA FAED EM CÉLULAS DE LIGAMENTO PERIODONTAL53

5.4 MORFOLOGIA CELULAR DE CÉLULAS DA MUCOSA GENGIVAL E LIGAMENTO PERIODONTAL TRATADAS COM FAED.

5.5 AVALIAÇÃO DO FECHAMENTO DA FERIDA (SCRATCH) .58

5.6 AVALIAÇÃO DA MIGRAÇÃO CELULAR (TRANSWELL) 60

5.7 AVALIAÇÃO DO POTENCIAL DE MINERALIZAÇÃO DAS CÉLULAS DO LIGAMENTO PERIODONTAL. .62

5.8 AVALIAÇÃO DA ATIVIDADE ANTIMICROBIANA DA EUGENIA DYSENTERICA .65

6 DISCUSSÃo. .67

7 CONCLUSÃO . .73

REFERENCIAS * . .74

ANEXo A - APROVAÇÃo PELO COMITÊ de ÉtiCA EM PESQUISA, CAAE No 35371514.5.0000.0030 .88

APÊNDICE A - TERMO DE CONSENTIMENTO LIVRE E ESCLARECIDO . .92 


\section{INTRODUÇÃO}

O uso terapêutico de plantas é registrado desde a antiguidade pelas civilizações da China, Índia, Egito e Grécia. Existem evidências históricas e arqueológicas de que as propriedades curativas das plantas medicinais já eram conhecidas há 60.000 anos. A Artemisia annua, como exemplo, foi descrita pela primeira vez na China durante a Dinastia Mawangdui Han, entre 206 a.C. a 220 d.C. $(1,2)$. Os egípcios, há mais de 4.000 anos, sabiam como preparar diuréticos, vermífugos, purgantes e antissépticos de origem natural. É possível, portanto, que os nossos ancestrais tenham aprendido o valor terapêutico das plantas $(3,4)$.

A fitoterapia é um método racional e alopático, empregado no tratamento de várias doenças. Estudos realizados com fitoterápicos utilizados em medicina vêm mostrando a eficácia de plantas medicinais no tratamento de doenças tais como o câncer (5-7), doença de Alzheimer (8), doença pulmonar obstrutiva crônica(9), diarreia e cólera (10), malária (11), estomatite (12), e doença periodontal (13-15).

No Brasil é largamente difundida a utilização de plantas medicinais em todas as regiões do país, muitas vezes sem oferecer uma garantia de qualidade, ter efeitos terapêuticos comprovados, composição padronizada e segurança de uso para a população $(16,17)$. No país há o senso comum de que "medicamento natural se não fizer bem, mal não faz", e de que tudo o que é natural é necessariamente benéfico. Porém, a planta medicinal é um xenobiótico, ou seja, um produto estranho ao organismo com finalidades terapêuticas. Esses produtos, ao serem introduzidos no organismo sofrem biotransformação e podem provocar efeitos adversos e toxicidade (18). Por isso, associando a medicina popular à tecnologia científica, podemos analisar e comprovar os efeitos de plantas medicinais sobre doenças existentes. Dessa forma, contribuindo para o desenvolvimento de biofármacos e o restabelecimento da saúde. E o Brasil, possuindo uma imensa biodiversidade vegetal, é um país com grande potencial de estudos na área. 
Alguns estudos já vêm sendo realizado em espécies vegetais advindas dos biomas do Brasil, sendo este considerado um país de maior diversidade biológica por abrigar cerca de $10 \%$ das formas viventes no planeta, o que pode representar cerca de 1,5 milhão de espécies existentes, entre vertebrados, invertebrados, plantas e microrganismos (19-22).

Dentre os biomas do país, o Cerrado é o segundo mais importante, ocupando uma área de 1,8 milhões de $\mathrm{Km}^{2}$, o que representa cerca de $25 \%$ do território brasileiro, estendendo-se principalmente pelos Estados de Minas Gerais, Goiás, Tocantins, Mato Grosso, Mato Grosso do Sul, Bahia, Maranhão, Piauí e Distrito Federal. Muitas espécies nativas do Cerrado fornecem frutos com altas concentrações de nutrientes, desempenhando papel importante na economia e nutrição da população desta região. Os caules, folhas e frutos nativos são comercializados na forma de doces, sorvetes, sucos e licores, e empregados também na medicina popular (23-25). Estudos in vitro e in vivo dessas plantas do Cerrado tem sido explorado com o objetivo de investigar as ações biomoleculares e efeitos em células, tecidos animais e microrganismos, como por exemplo a citronela, a canela (26), o alecrim-pimenta (27), o barbatimão (28), o gengibre (29), o boldo (30) e a cagaita (31).

A Eugenia dysenterica, também conhecida como cagaita, foi relatada em diferentes estudos apresentando potencial antifúngico (32), antioxidativo (33) e citoprotetor (31). Uma vez que estudos anteriores mostraram efeitos de plantas em tecidos animais e em microrganismos, esse trabalho tem como proposta a utilização da Eugenia dysenterica, uma planta pertencente ao cerrado brasileiro, em células de mucosa gengival e ligamento periodontal humano, visto que são necessários estudos para que sejam conhecidos os efeitos biológicos sobre esses tecidos. 


\section{REVISÃO DE LITERATURA}

\subsection{TECIDOS PERIODONTAIS}

O periodonto é um conjunto de tecidos que sustentam e protegem os dentes (Figura 1), sendo constituído por tecidos de origem epitelial e conjuntivo. $O$ periodonto pode ser dividido em periodonto de proteção, que é constituído pela gengiva marginal e papilar, e periodonto de inserção, composto por cemento, ligamento periodontal e osso alveolar (34). A gengiva recobre os processos alveolares e protege os tecidos subjacentes. O ligamento periodontal é o tecido da porção radicular do dente que liga o osso alveolar ao cemento. O cemento é um tecido conjuntivo frouxo formado por fibras inseridas no osso alveolar e cemento. $O$ cemento é um tecido mineralizado que recobre a dentina radicular inserindo as fibras do ligamento periodontal. O osso alveolar reveste o alvéolo e também insere as fibras do ligamento periodontal, garantindo a sustentação do dente em seu alvéolo $(35,36)$.

As células do ligamento periodontal incluem os fibroblastos, cementoblastos, osteoblastos e células-tronco progenitoras. Os fibroblastos são as células mais comuns no ligamento periodontal, as quais sintetizam e secreram colágeno e apresentam-se em formato fusiforme ao longo das fibras colágenas. Os cementoblastos e restos epiteliais de Malassez, originados da bainha epitelial de Hertwig, e os osteoblastos encontram-se na superfície do cemento e osso alveolar, respectivamente (36).

McCulloch e colaboradores, 1987 (37), descreveram que o tecido periodontal tem capacidade de se remodelar, evidenciado pelo seu rápido turnover. E eles apresentaram a evidência de que existam células-tronco progenitoras presentes no ligamento periodontal. Durante o reparo periodontal, devido à inflamação crônica, é necessário que estejam disponíveis tais células e que esteja presente os sinais 
responsáveis pela diferenciação. As células células-tronco progenitoras, têm características pluripotentes capazes de secretar as proteínas da matriz extracelular, dentre elas as fibras colágenas que se organizam, e se diferenciarem em osteoblasto, cementoblasto e fibroblasto, participando no reparo tecidual $(38,39)$.

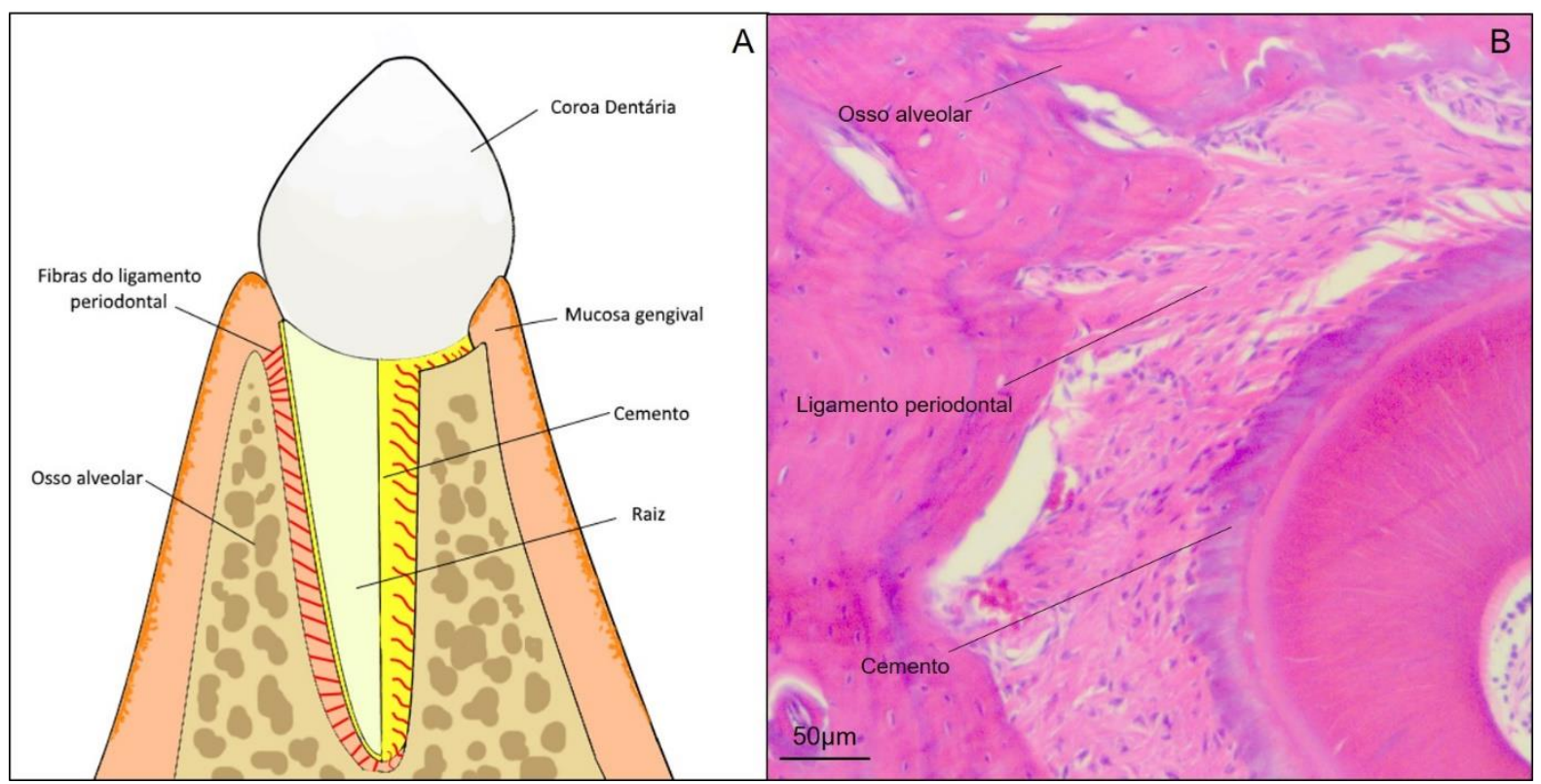

Figura 1. Esquema ilustrativo do dente e seus tecidos de suporte periodontal. A: Na figura observamos o dente no alvéolo dentário. O cemento (amarelo) revestindo a raiz do dente e a disposição das fibras do ligamento periodontal (vermelho) entre o cemento e o osso alveolar. B: Imagem histológica de corte axial da raiz dentária e seus tecidos de suporte. Fonte: Próprio autor.

A periodontite é uma doença periodontal inflamatória destrutiva dos tecidos que sustentam os dentes. Esta patologia leva à dor, deficiência na mastigação, comprometimentos estéticos e sistêmicos, além de ser a principal causa de perda de dentes em humanos e a mais prevalente associadas à perda óssea (40).

Após instalação da periodontite, o organismo começa uma série de eventos biológicos na tentativa de reparar os tecidos perdidos. Desta forma, há a tentativa do organismo em reconstruir os tecidos e restaurar as funções originais, conhecida como regeneração (41). 
Atualmente o tratamento de periodontite e reparo dos tecidos periodontais têm sido um desafio. O principal objetivo do tratamento periodontal é regenerar a estrutura de suporte e formar novo osso alveolar, cemento e ligamento periodontal (42). Atualmente o tratamento da doença periodontal envolve procedimentos de debridamento mecânico (raspagem e alisamento radicular), terapias químicas com o objetivo de alterar o biofilme dentário que induz as respostas inflamatórias destrutivas (34). Em casos mais avançados a utilização das chamadas técnicas de regeneração periodontal, tais como regeneração tecidual guiada, enxertos ósseos, uso de biomateriais, e aplicação de fatores de crescimento têm sido usado na tentativa de recuperar os tecidos perdidos $(38,43)$, muitas vezes associada à administração de antibióticos de ação sistêmica (44).

Clinicamente, o tratamento periodontal convencional, não cirúrgico e cirúrgico, geralmente leva a melhorias significativas, tais como o controle do processo inflamatório, a diminuição da profundidade de sondagem das bolsas periodontais e ganho de inserção clínica. Para casos de ganho em quantidade óssea, o tratamento periodontal regenerativo constitui o tratamento ideal, porém acontece uma perda significativa de inserção clínica (42). É importante também salientar que o processo de reparo dos tecidos periodontais só pode ser demonstrado e confirmado pelo estudo histológico (42).

Assim, as indicações e resultados do tratamento periodontal convencional nem sempre são bem sucedidos e apresentam limitações. Dessa forma, avanços em biologia molecular e medicina regenerativa têm trazido novas abordagens em engenharia tecidual e terapias baseadas em genes de reparo dos tecidos periodontais $(45,46)$. Para isso, estudos com plantas e seus compostos têm sido descritos com o intuito de reparar os tecidos periodontais e curar as doenças acometidas nesses tecidos (15). 


\subsection{PLANTAS MEDICINAIS E A UTILIZAÇÃO EM ODONTOLOGIA}

A incorporação e a importância do uso de plantas medicinais e fitoterápicos no Sistema Único de Saúde (SUS) aconteceu em 2003 durante a 1a Conferência Nacional de Medicamentos e Assistência Farmacêutica (47). Em julho de 2008, realizado em Brasília, o Fórum de Práticas Integrativas e Terapias Complementares em Odontologia regulamentou o uso da fitoterapia na odontologia brasileira, prática esta que, uma vez inserida poderá elevar consideravelmente a redução de custos do SUS (48). Assim sendo, torna-se importante viabilizar pesquisas que têm como princípio o uso de plantas sobre a prática de cuidados com saúde no país. Pensando assim, o Brasil se torna um grande potencial para pesquisa devido à sua ampla biodiversidade, considerando a complementaridade e a integração entre os conhecimentos advindos das práticas populares e os conhecimentos desenvolvidos pela ciência e tecnologia na perspectiva de desenvolvimento sustentável.

Recentemente, medicamentos à base de plantas tem recebido atenção considerável como opções terapêuticas no tratamento de inúmeras doenças (49-51). Os pesquisadores têm investigado e determinado os compostos bioativos como responsáveis pelos efeitos farmacológicos de plantas medicinais, e vários fitoquímicos foram estudados para determinar os efeitos terapêuticos de produtos naturais (52).

$\mathrm{Na}$ literatura é possível encontrar relatos sobre a utilização de plantas medicinais para doenças bucais, apresentando propriedades relevantes para a odontologia. Na medicina oral, plantas e seus compostos têm sido estudados para tratar doenças periodontais, lesões orais, cáries e infecções (53).

Estudos recentes têm demonstrado efeitos das plantas na atividade antiinflamatória e reparativa de tecidos gengivais (54). Rodanant e colaboradores, 2015 (55), avaliaram a ação do extrato de folhas de Murraya paniculata (Murta-de-cheiro) contra microrganismos da cavidade oral e constataram potentes propriedades antiinflamatórias, utilizando fibroblastos gengivais humanos e monócitos. Lins e 
colaboradores, 2013 (56), consideraram satisfatórios o uso de Matricaria recutita (Camomila) e de Schinus terebinthifolius (Aroeira) na redução do quadro de inflamação por gengivite, reduzindo significativamente o sangramento gengival. Além disso, também observaram redução no índice de placa bacteriana presente nos indivíduos estudados.

Meckelburg e colaboradores, 2014 (57), relataram a ação de Coffea canephora no controle do biofilme dental. A planta causou lise bacteriana e por consequência houve liberação de cálcio para o meio bucal, podendo concluir a ação da planta em microrganismos bucais, sendo considerado o potencial anticariogênico e antimicrobiano natural. Além disso, a mineralização e diferenciação osteogênica em cultura primária de células do ligamento periodontal, foi relatada com a utilização de diferentes tipos de plantas em estudo in vitro e in vivo, apresentando expressões gênicas e proteicas (15).

Além disso, a presença de compostos fenólicos em plantas tem sido bastante estudada por apresentarem atividades farmacológicas e por inibirem a oxidação lipídica e a proliferação de fungos $(15,58,59)$. Há evidências de que compostos fenólicos exercem efeitos moduladores em células pela ação seletiva em diferentes componentes das cascatas de sinalização intracelular, vitais para funções como o crescimento, proliferação e apoptose (60). Os compostos fenólicos são referidos como polifenóis, e podem ser classificados basicamente como: os ácidos fenólicos, flavonoides, taninos, e cumarinas. Alguns tipos de compostos fenólicos são pouco distribuídos e encontrados em número reduzido na natureza, e alguns não se encontram livres nos tecidos vegetais, portanto são solúveis em água e em solventes orgânicos, como no caso dos taninos. Os taninos possuem alto peso molecular e dá aos alimentos a sensação de adstringência. Estudos indicaram que os taninos inibem o consumo alimentar, no entanto, estudos recentes concluem que ele diminui a conversão de nutrientes absorvidos. Além disso, os taninos têm como propriedade a ação antioxidante, que é importante na proteção dos danos oxidativos celulares $(61,62)$. Os flavonoides são os compostos mais abundantes na dieta humana, sendo responsáveis por mais da metade dos compostos que ocorrem naturalmente, e possuem um baixo peso molecular. Já está bem reconhecido que os flavonoides possuem atividades antitumoral, de agregação antiplaquetária, 
antialérgica, anti-inflamatória, e antibacterianas. Além disso, os flavonoides exibem um potencial para a indução de diferenciação celular e mineralização $(63,64)$.

No entanto, o uso de plantas para o tratamento de doenças bucais ainda não se tornou rotina. Tal fato se deve aos poucos estudos realizados, faltando comprovação científica acerca da eficácia e segurança em seu uso. Dessa forma, contando com uma biodiversidade de plantas presente no bioma brasileiro, é de grande relevância científica e econômica as pesquisas para a descoberta de novas possibilidades terapêuticas para o uso de fitoterápicos em Odontologia. 


\subsection{EUGENIA DYSENTERICA}

Dentre as inúmeras plantas nativas que apresentam potencial de utilização popular e comercial, encontra-se a Eugenia dysenterica, uma árvore pertencente à família Myrtaceae, popularmente conhecida como cagaita ou cagaiteira, devido à capacidade laxativa de seu fruto. A cagaiteira é uma árvore de altura mediana (4 a $10 \mathrm{~m}$ ) (Figura 2), que apresenta frutos como uma esfera achatada de casca frágil e cor amarela brilhante. No interior apresenta polpa suculenta e sementes achatadas na cor creme, a qual tem sido utilizada para fins alimentícios, sendo consumida in natura (65), ou processada para a produção de sorvetes, doces, geleias, licores, álcool e vinagre (66-68).

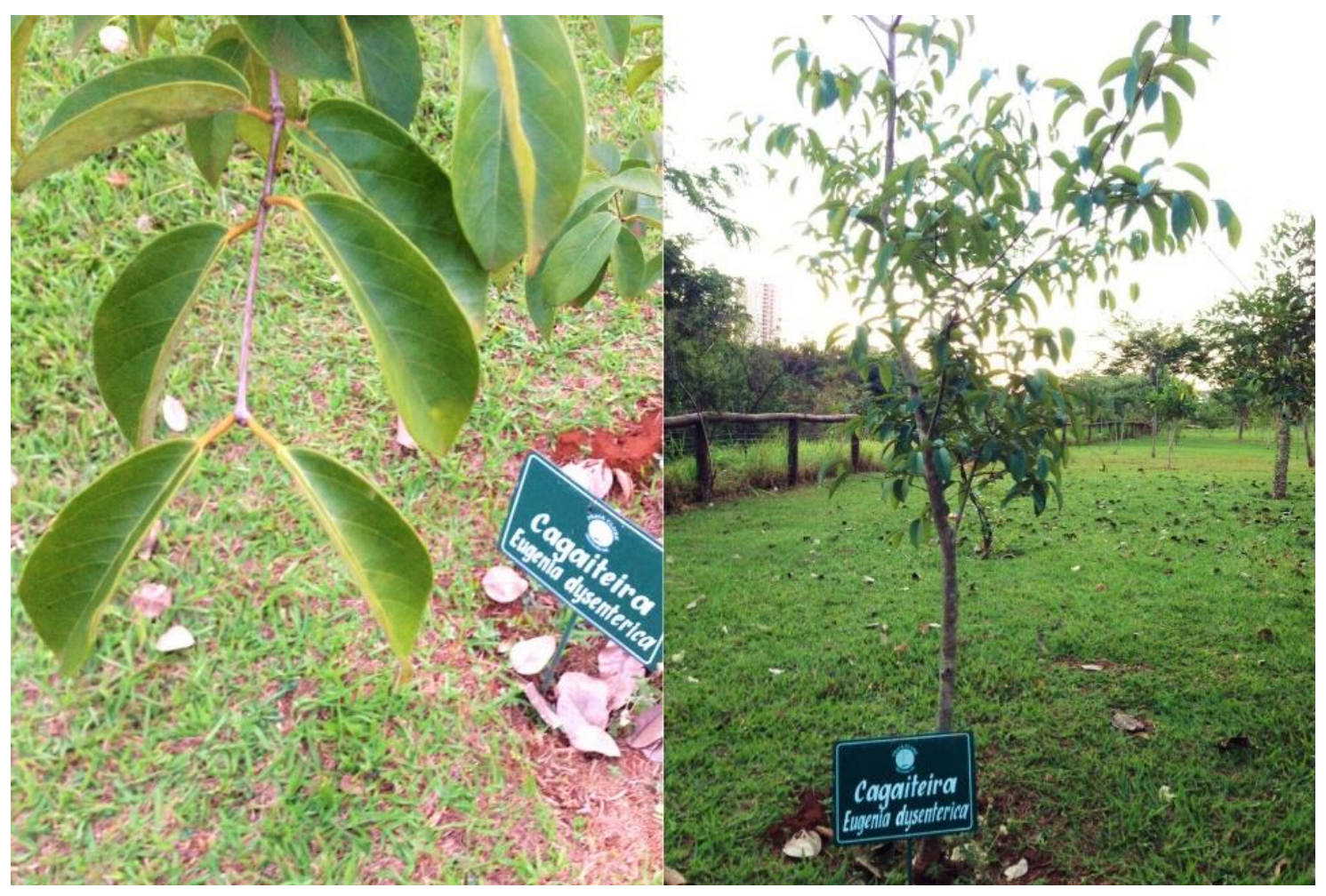

Figura 2. Eugenia dysenterica: Folhas e árvore da cagaiteira jovem. Planta localizada na cidade de Uberlândia, Minas Gerais, Brasil. Fonte: próprio autor. 
De todas as características físicas, a polpa mostrou ser a mais importante para a exploração econômica, com alto rendimento de $86,4 \%$, porém, apresentou um baixo valor energético, associado ao baixo teor de macro nutrientes. A Eugenia dysenterica é fonte de vitamina $\mathrm{C}$ e folatos (B9), mas apresentou baixo teor de carotenoides, sendo a provitamina A a principal encontrada $(23,69)$. $\mathrm{O} \mathrm{pH}$ do fruto é ácido e apresenta uma alta concentração de água em torno de $90 \%$, carboidratos e lipídios (70).

O uso alimentar da Eugenia dysenterica é bastante difundido na região centro-oeste do Brasil, sendo consumido in natura, com apenas algumas precauções em relação à quantidade ingerida. Estudos recentes fornecem suporte para alguns dos efeitos descritos pela população. Estudos de Roesler e colaboradores, 2007 (71), indicam a presença de compostos com alto potencial antioxidante nos extratos das frações das frutas. Seus estudos também observaram que o fruto é bastante susceptível à fermentação e a exposição ao sol acelera esse processo tornando a Eugenia dysenterica um laxante natural. Ainda, suas folhas são usadas tradicionalmente no tratamento de diarreia, desordens dos sistemas genitourinário, cardiovasculares e como cicatrizante (72).

Em recente estudo, Galheigo e colaboradores, 2016 (73), relacionaram o óleo essecial a partir das folhas de Eugenia dysenterica com a capacidade de alterar a secreção intestinal e o processo de absorção, resultando em um efeito antidiarreico. Tal resultado sugere que a ação das folhas não se dá pelos componentes polifenóicos e sim pelos componentes voláteis. Lima e colaboradores, 2010 (74), demonstraram que a atividade antidiarreica do extrato de folhas de Eugenia dysenterica está associada ao aumento da motilidade gastrointestinal em camundongos, aproximadamente $28 \%$, sem causar diarreia. $O$ efeito laxativo parece estar relacionado a um peptídeo ainda não identificado presente na Eugenia dysenterica. Nas análises hematológicas e histopatológicas não foram observadas alterações celulares e toxicidade nos mamíferos avaliados, comparado aos laxantes comerciais. Cecilio e colaboradores, 2012 (75), também demostraram que o extrato das folhas revelaram potencial atividade in vitro em rotavírus e fungos, o que confirma a sua utilização farmacológica para tratar diarreia e disenteria. 
O óleo essencial das folhas é ricos em sesquiterpenos, como o $\beta$-cariofileno e o a-humuleno, e monoterpenos, como o limoneno e o alfatugeno, apresentando propriedades antifúngicas à cagaita $(32,76,77)$. Além disso, polpas congeladas exibem elevada $\alpha$-glicosidase e atividade inibitória da $\alpha$-amilase, representando um potencial fármaco para o tratamento de diabetes (78).

Vieira e colaboradores, 2012 (79), reportaram o uso das folhas de Eugenia dysenterica como alarmante ao uso de chás utilizados frequentemente pela população para o tratamento de diarreia. Seus estudos indicam que o extrato liofilizado da cagaita exibiu efeito citotóxico e genotóxico nos eritrócitos policromáticos em células de medula óssea de camundongos, quando em doses elevadas. Lima e colaboradores, 2011 (80), também analisaram o comportamento in vivo de folhas, encontrando que o extrato etanólico e a infusão de folhas de Eugenia dysenterica foram tóxicos à ratos Wistar.

Em 2012, Souza e colaboradores, 2012 (22), relataram pela primeira vez a ação do extrato de Eugenia dysenterica em células da pele, demonstrando ausência de efeito citotóxico, sobretudo em queratinócitos e fibroblastos. Seus estudos revelaram uma potencial atividade inibitória sobre a enzima tirosinase, podendo ser utilizado como clareamento da pele ou cosmético para terapia antimelanogênica.

Prado e colaboradores, 2014 (31), evidenciaram o potencial biofarmacológico do extrato liofilizado das folhas da cagaiteira. O estudo demonstrou um efeito de proteção da mucosa gástrica de lesões por HCl/etanol. Tal efeito parece se dar pela ação antioxidante e de compostos sulfídricos endógenos, e a presença de taninos condensados.

Em estudo recente, Avila e colaboradores, 2016 (81), mostraram ação antioxidativa e citoprotetora do extrato de Eugenia dysenterica em macrófagos de alvéolos pulmonares de murinos expostos ao cromo hexavalente, um metal tóxico que favorece a morte celular por apoptose. Além disso, em estudo in vivo, relataram um aumento da sobrevida de camundongos que foram expostos a uma dose letal de cromo. Com tratamento profilático utilizando o extrato, observaram a redução dos níveis de cromo nos rins, fígado e plasma, e prevenção de alterações hepáticas e renais. 
Coletivamente, estes efeitos antioxidante, antifúngico, e citoprotetor da Eugenia dysenterica sobre tecidos humanos ainda parecem estar em desenvolvimento. No entanto, sugerem um bom potencial para a sua aplicação terapêutica em diversas doenças, inclusive nas que acometem os tecidos dentários.

\subsection{EUGENIA DYSENTERICA E TECIDOS PERIODONTAIS}

Até o presente, os efeitos da Eugenia dysenterica em tecidos dentários humanos ainda não foram descritos na literatura. Com a finalidade de melhor utilização desta planta do cerrado como um biofármaco, este estudo tem como objetivo avaliar os efeitos da Eugenia dysenterica em cultura primária de tecidos periodontais humanos, especificamente de células de mucosa gengival e ligamento periodontal humanos, para, assim, oferecer uma nova abordagem terapêutica segura e eficaz para o tratamento de doenças na Odontologia. 


\section{OBJETIVOS}

\subsection{OBJETIVO GERAL:}

Avaliar os efeitos da Eugenia dysenterica em cultura primária de células da mucosa gengival e do ligamento periodontal em humanos.

\subsection{OBJETIVOS ESPECÍFICOS:}

3.2.1 Estabelecer cultura primária de células da mucosa gengival e do ligamento periodontal de dentes com indicação de exodontia;

3.2.2 Avaliar a viabilidade celular da cultura primária estabelecida dos tecidos dentários, após tratamento com a fração acetônica do extrato aquoso de folhas de Eugenia dysenterica (FAED);

3.2.3 Estabelecer as concentrações ideais da FAED para tratamento dos tecidos de musosa gengival e ligamento periodontal;

3.2.4 Analisar a morfologia celular da cultura primária de células dos tecidos após tratamento com FAED;

3.2.5 Avaliar o potencial de proliferação e migração de células de mucosa gengival após tratamento com FAED;

3.2.6 Investigar o papel da FAED na mineralização e diferenciação osteogênica das células do ligamento periodontal.

3.2.7 Avaliar e comparar a atividade antimicrobiana do digluconato de clorexidina combinado com a FAED. 


\section{METODOLOGIA}

\subsection{OBTENÇÃO DE MUCOSA GENGIVAL E LIGAMENTO PERIODONTAL HUMANOS E ESTABELECIMENTO DE CULTURA PRIMÁRIA DE CÉLULAS}

As mucosas gengivais e ligamentos periodontais humanos foram obtidos a partir de dentes extraídos com indicação clínica e cedidos pelos pacientes, acompanhados por meio da assinatura do Termo de Consentimento Livre e Esclarecido, seguindo as recomendações da Resolução 466/2012 do Conselho Nacional de Saúde. Esse projeto foi aprovado pelo comitê de ética da Faculdade de Ciências da Saúde da Universidade de Brasília, de número CAAE: 35371514.5.0000.0030.

Participaram desse estudo 10 indivíduos com idade entre 18 e 24 anos, de ambos os sexos e saudáveis, que não apresentavam alterações sistêmicas ou locais, e nem fazem uso de medicamentos, durante o tempo de execução da pesquisa, além de apresentarem boa higiene. Somente as células do ligamento periodontal e da mucosa gengival foram utilizadas na presente pesquisa. Os fragmentos remanescentes foram descartados como lixo biológico.

Foram selecionados dentes e regiões de terceiros molares ou pré-molares com indicação prévia para exodontia. Os dentes estavam íntegros e sem lesões cariosas ou doença periodontal, e os processos cirúrgicos foram realizados conforme o protocolo de biossegurança. Os dentes selecionados não passaram por desgastes de odontossecção ou osteotomia para não haver risco de contaminações dos tecidos selecionados. Imediatamente após a exodontia, os dentes e mucosas gengivais, removidas com lâmina de bisturi, foram colocados em tubo Falcon de 15 $\mathrm{mL}$ contendo $5 \mathrm{~mL}$ de meio de biópsia Dulbecco's Modified Eagle's Medium (DMEM) (Gibco®, Invitrogen, Carlsbad, CA, EUA), $20 \%$ de soro fetal bovino (FBS) (Invitrogen) e 2\% de Anti-Anti (Invitrogen). 
Posteriormente, na capela de fluxo laminar, os dentes e mucosas gengivais foram lavados (Figuras 3A e 4A) por três a cinco vezes, durante 1 minuto, com meio de biópsia sobre um prato de 100 mm (Corning Incorporation, Lowell, MA, EUA).
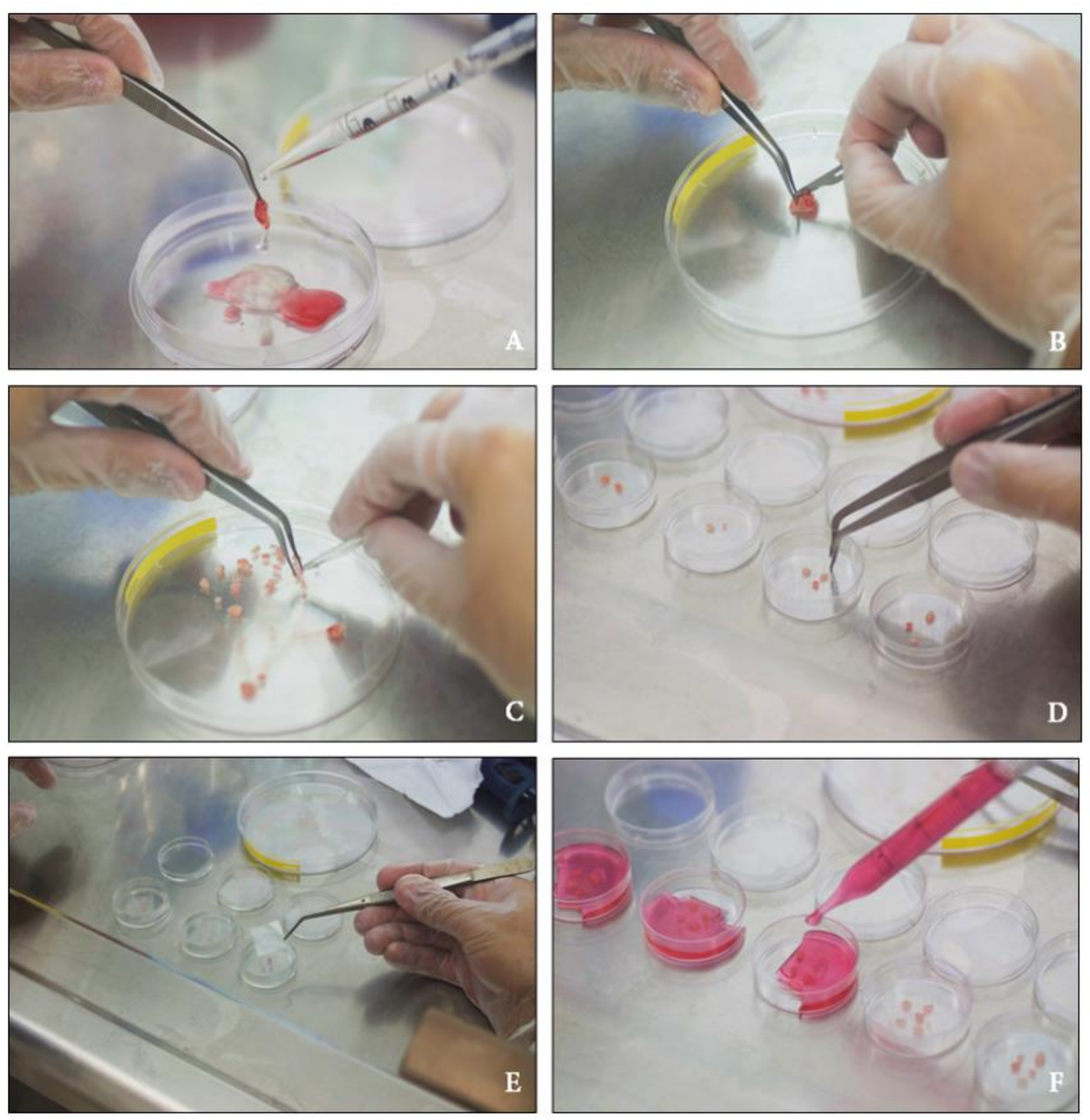

Figura 3. Etapas para cultivo celular pela técnica de explant. A: Lavagem do fragmento gengival com PBS. B e C: Obtenção dos fragmentos gengivais por meio de secção com lâmina de bisturi. D: Fragmentos dispostos em pratos de cultura de $35 \mathrm{~mm}$. E: Fragmentos fixados com lamínulas de vidro estéreis. F: Adição de $2 \mathrm{~mL}$ de meio de cultura. 
Primeiramente foram coletadas as mucosas gengivais e estabelecido a cultura celular pela técnica de explant, ou seja, a partir da cultura de pequenos fragmentos da gengiva, denominados explantes. Este método também é conhecido por outgrowth, apresentando baixo custo e simplicidade na execução (82). No entanto, é necessário um período de tempo maior para que sejam estabelecidas as células, pois estas precisam migrar do fragmento para a placa de cultura celular. Por isso, há uma menor heterogeneidade devido à cultura ser constituída apenas pelas células que conseguem migrar do fragmento gengival (83). Após a lavagem com meio de biópsia, os tecidos gengivais foram particulados sobre um prato de cultura com a ajuda de uma pinça e lâmina de bisturi nำ15 (Solidor, Suzhou, CH) (Figuras 3B e 3C). Os tecidos particulados foram transferidos individualmente para um prato de cultura de $35 \mathrm{~mm}$ (Corning) com o fundo preparado com ranhuras (Figura 3D) e, por cima dos tecidos, uma lamínula estéril para estabilização (Figura 3E). Após a colocação da lamínula foi acrescentado $2 \mathrm{~mL}$ de meio de biópsia (Figura 3F) e levados à incubadora à $37^{\circ} \mathrm{C}$ em atmosfera saturada em $5 \%$ de $\mathrm{CO}_{2}$ e $98 \%$ de umidade, para assim dar início à proliferação e obtenção de fibroblastos gengivais.

As células de ligamento periodontal foram obtidas pela técnica de digestão enzimática. Essa técnica se baseia no isolamento de células por um processo de dissociação do tecido, tendo como vantagens o melhor aproveitamento do material coletado e menor tempo para obtenção do estabelecimento da cultura celular (84). Diferente das células gengivais, as células do ligamento periodontal apresentam proliferação mais lenta que estas. Foram removidos os tecidos do terço médio da raiz com uma cureta periodontal pouco afiada (Figura 4B). Os tecidos de ligamento periodontal de cada dente foram transferidos individualmente para um prato de cultura de $35 \mathrm{~mm}$ (Corning) (Figura 4C), acrescido de $3 \mathrm{~mL}$ da solução de colagenase/dispase (Figura 4D), contendo $3 \mathrm{mg} / \mathrm{mL}$ de Collagenase Type I (Invitrogen) e $4 \mathrm{mg} / \mathrm{mL}$ de Dispase II (Invitrogen) diluídos em DMEM (Gibco®), e incubados a $37^{\circ} \mathrm{C}$ por $1 \mathrm{~h}$. Após o período de incubação, a solução com o tecido foi aspirada com ajuda de uma seringa hipodérmica fina. Com o auxílio da própria seringa, a solução com o tecido foi passada pelo separador celular de $100 \mu \mathrm{m}$ de diâmetro (SPL Life Science) apoiado sobre um tubo Falcon de $50 \mathrm{~mL}$ (Figura 4E) e, em seguida, lavado com mais $4 \mathrm{~mL}$ de meio de biópsia. A solução com as células foi transferida para um tubo Falcon de $15 \mathrm{~mL}$ e centrifugada a $2500 \mathrm{rpm}$ por $5 \mathrm{~min}$. O 
sobrenadante foi aspirado, ressuspendido o pellet celular em $5 \mathrm{~mL}$ de meio de biópsia e transferido para uma placa (Corning) de $25 \mathrm{~cm}^{2}$ (Figura 4F), que foi colocada na incubadora a $37^{\circ} \mathrm{C}$ em atmosfera saturada em $5 \%$ de $\mathrm{CO}_{2}$ e $98 \%$ de umidade.
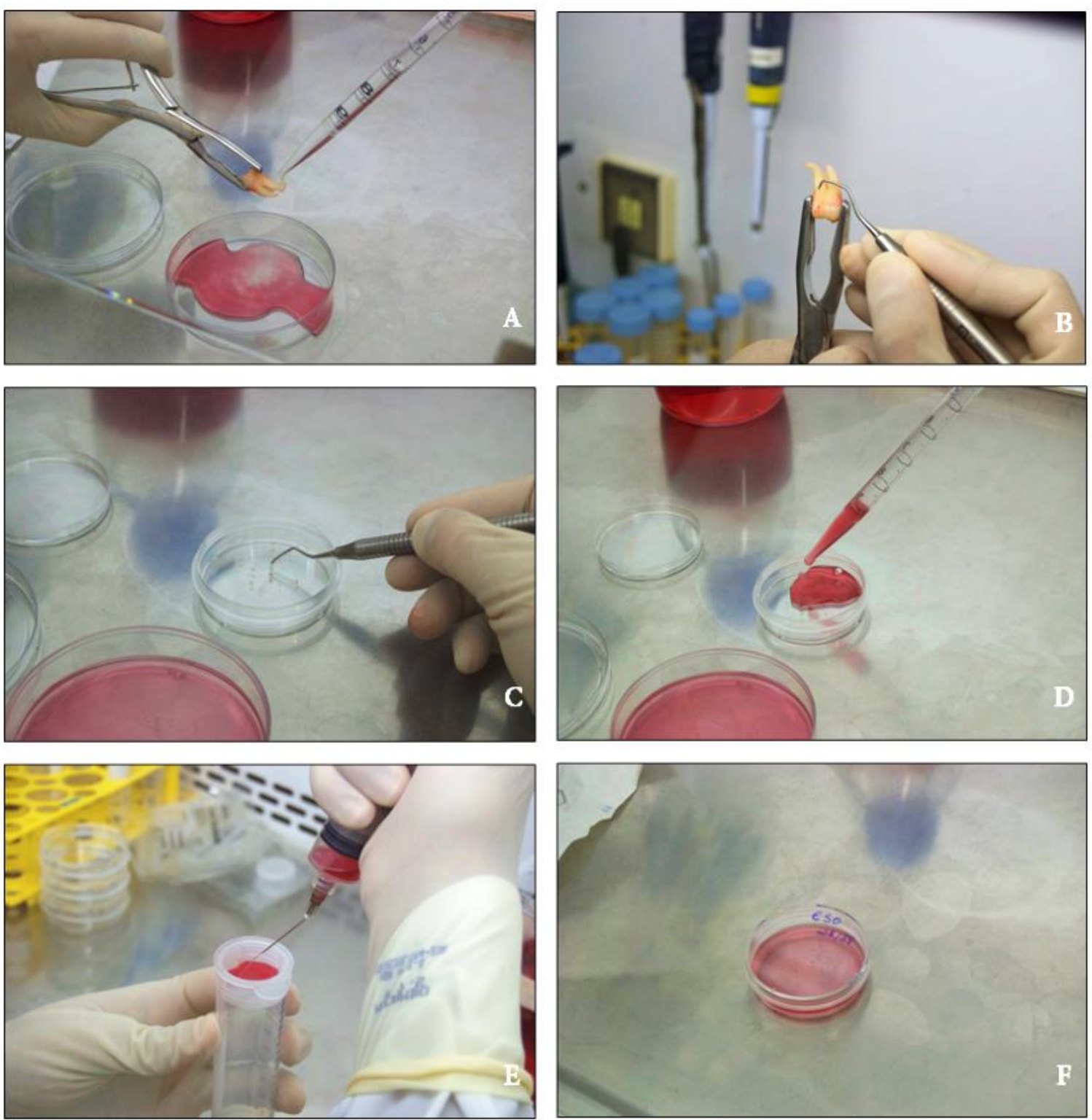

Figura 4. Etapas para cultivo celular pela técnica de digestão enzimática. A: Lavagem do dente com PBS. B: Remoção do ligamento periodontal com ajuda de uma cureta. C: Fragmentos depositados em um prato de $35 \mathrm{~mm}$. D: Adição de $3 \mathrm{~mL}$ de solução enzimática de colagenase/dispase. E: Solução com tecido sendo passada pelo separador celular. F: Prato de cultura celular com meio e células. 
O material coletado foi armazenado em congelador a $-80^{\circ} \mathrm{C}$. Posteriormente, as células foram descongeladas e utilizadas para os ensaios entre as passagens celulares 3 e 7 .

\subsection{OBTENÇÃO DO EXTRATO DE EUGENIA DYSENTERICA}

O extrato utilizado na pesquisa foi oriundo do bioma Cerrado (em Brasília e entorno) e cedidos da coleção de extratos do projeto Centro-Oeste, pertencente ao Laboratório de Produtos Naturais da FS/UnB, sob voucher UB 914 identificado pela Professora Doutora Sueli Maria Gomes do Instituto de Ciências Biológias da Universidade de Brasília. As folhas de Eugenia dysenterica foram coletadas e secas em temperatura ambiente. Após secagem as folhas foram trituradas e colocadas em infusão de $200 \mathrm{~g}$ do material em $1 \mathrm{~L}$ de água destilada a $70^{\circ} \mathrm{C}$ em recipiente fechado. Após a infusão chegar a $40^{\circ} \mathrm{C}$ a solução obtida foi filtrada e liofilizada. $O$ extrato bruto aquoso de Eugenia dysenterica foi obtido e posteriormente submetido à precipitação de substâncias por lavagem com acetona, utilizado como um solvente puro. Ao extrato bruto aquoso de Eugenia dysenterica, foi misturado $30 \mathrm{~mL}$ do solvente e homogeneizados, com posterior separação do precipitado e sobrenadante após decantação. Este procedimento foi repetido três vezes e, em seguida, realizada a evaporação, obtendo-se a fração acetônica do extrato bruto aquoso da planta. A fração obtida foi mantida sob refrigeração $\left(-30^{\circ} \mathrm{C}\right)$ até ser usado nos testes. O rendimento do extrato bruto aquoso de Eugenia dysenterica foi de $9,27 \%$ e da fração acetônica foi de $1,67 \%$. 


\subsection{TESTE DE CITOTOXICIDADE CELULAR}

A citotoxicidade ocasionada pela FAED foi aferida utilizando o teste de avaliação da atividade mitocondrial das células, que avalia a capacidade das enzimas mitocondriais celulares em converterem sais de MTT (brometo de 3-(4,5dimetiltiazol-2-il)-2,5-difenil) tetrazólio) em formazam. Assim somente as células viáveis têm a capacidade de fazer essa redução e por isso a absorbância medida corresponde às células viáveis, ou às células que não sofreram toxicidade suficiente para reduzir sua atividade mitocondrial. O produto de formazam apresenta uma coloração arroxeada diferente da cor inicial dos sais de tetrazólio que, após serem diluídos em solvente de veículo alcoólico, podem ter sua absorbância aferida em uma leitora de microplaca (Thermo Plate TP Reader) a $570 \mathrm{~nm}$ e comparada a absorbância do grupo controle.

Com o teste MTT foram estabelecidos o tipo de extrato e a concentração para início do tratamento. Para isso as células foram semeadas em placas de 96 poços nas concentrações $5 \times 10^{3} \mathrm{cel} /$ poço, $8 \times 10^{3} \mathrm{cel} /$ poço e $1 \times 10^{4} \mathrm{cel} /$ poço, e incubadas por 24 horas. Após esse período as células foram tratadas com extrato bruto de Eugenia dysenterica à $83 \mu \mathrm{g} / \mathrm{mL}$ e $167 \mu \mathrm{g} / \mathrm{mL}$, fração acetônica de extrato bruto de Eugenia dysenterica (FAED) à $83 \mu \mathrm{g} / \mathrm{mL}$ e $167 \mu \mathrm{g} / \mathrm{mL}$, e seu respectivo controle negativo utilizando meio DMEM acrescido $2 \%$ de FBS. Tais concentrações iniciais se deram à observação de estudos anteriores de nossa equipe de pesquisas proposto por Silva 2013 (85), em seus estudos com microrganismos, e por Souza e colaboradores, 2012 (22), em estudos da planta com queratinócitos.

Após 24, 48 e 72 horas de tratamento as células foram retiradas da incubadora, e a cada $100 \mu \mathrm{L}$ de meio com extrato foram acrescentados $10 \mu \mathrm{L}$ de substrato MTT (Sigma - Aldrich, EUA) em cada poço. As placas eram protegidas de luminosidade com papel alumínio e retornavam a incubadora e mantidas em condições ideais por 4 horas. Decorrido este tempo o meio com substrato de MTT foi aspirado de cada poço e acrescentado $100 \mu \mathrm{L}$ de isopropanol acidificado $(25 \mathrm{~mL}$ de isopropanol $+104 \mu \mathrm{L} \mathrm{HCl} \mathrm{100 \% ).} \mathrm{As} \mathrm{placas} \mathrm{foram} \mathrm{agitadas} \mathrm{em} \mathrm{vortex} \mathrm{na} \mathrm{velocidade}$ mínima por 10 minutos, tempo suficiente para causar a diluição dos sais de tetrazólio 
no veículo alcoólico. Finalmente para obter a citotoxicidade induzida pelo tratamento a absorbância das células foi aferida e comparada ao controle negativo, estabelecido como $100 \%$ de células viáveis.

Após esse primeiro teste de MTT foram definidos a concentração de células por poço e o tipo de extrato a ser utilizado. Com isso, foram testadas variadas concentrações do extrato de Eugenia dysenterica para estabelecer qual a de menor citotoxicidade para as células gengivais. Foram assim utilizadas as concentrações de $0,25 \mu \mathrm{g} / \mathrm{mL}, 0,5 \mu \mathrm{g} / \mathrm{mL}, 1,0 \mu \mathrm{g} / \mathrm{mL}, 2,0 \mu \mathrm{g} / \mathrm{mL}, 4,1 \mu \mathrm{g} / \mathrm{mL}, 8,3 \mu \mathrm{g} / \mathrm{mL}, 20,75 \mu \mathrm{g} / \mathrm{mL}$, $41,5 \mu \mathrm{g} / \mathrm{mL}$ e $83 \mu \mathrm{g} / \mathrm{mL}$ de fração acetônica do extrato de folhas de Eugenia dysenterica, seguindo o mesmo protocolo de MTT utilizado. Após o estabelecimento foi testada a concentração de menor citotoxicidade comparada ao controle negativo com meio DMEM à $2 \%$ de FBS e também ao controle positivo com o uso do digluconato de clorexidina à $0,12 \%$ e $0,2 \%$.

Com a linhagem de células do ligamento periodontal foi inicialmente realizado o MTT com o mesmo método utilizado para as células de mucosa gengival utilizando FAED na concentração de $83 \mu \mathrm{g} / \mathrm{mL}$. Em seguida foi realizado também o MTT com as concentrações de $8,3 \mu \mathrm{g} / \mathrm{mL}, 20,75 \mu \mathrm{g} / \mathrm{mL}, 41,5 \mu \mathrm{g} / \mathrm{mL}$ e $83 \mu \mathrm{g} / \mathrm{mL}$. 


\subsection{ANÁLISE DE MORFOLOGIA CELULAR}

Para a análise morfológica, após o tratamento com a fração acetônica do extrato bruto aquoso das folhas de Eugenia dysenterica, as células foram analisadas em microscópio de contraste de fase e luz invertida (Zeiss Primo Vert, Göttingen, Alemanha), equipado com câmera digital (Zeiss ERC 5s, Göttingen, Alemanha) em objetiva de 4x, 10x e 20x com o software ZEN Blue Edition (Zeiss, Göttingen, Alemanha).

As células gengivais foram analisadas em 24, 48 e 72 horas após o tratamento e as células do ligamento periodontal foram analisadas após 24 horas, 3, 7, 14 e 21 dias após o tratamento. 


\subsection{TESTE DE FECHAMENTO DE LESÃO E MIGRAÇÃO CELULAR}

\subsubsection{Teste de fechamento de lesão em monocamada (Scratch assay)}

O ensaio de scratch (fechamento de ferida) permite avaliar o efeito proliferativo e migratório de células sem a necessidade do uso de agentes quimiotáticos que podem influenciar os resultados. O resultado esperado é a migração celular observada pelo fechamento de uma lesão, por um dado período de tempo.

Para verificar a capacidade de fechamento de lesão e potencial de migração celular pós realização de ferida (scratch), as células foram plaqueadas em placas de 6 poços, previamente revestidas com $10 \mu \mathrm{g} / \mathrm{mL}$ de fibronectina (Sigma Aldrich, St Louis, EUA) e mantidas overnight, na concentração de $1 \times 10^{6}$ células por poço, e meio DMEM a 10\% FBS. Após 24 horas foram lavadas com PBS e mantidas na incubadora com meio DMEM, sem adicionar FBS a fim de induzir a quiescência das células, ou seja, as células entram em repouso durante a fase de divisão celular, fazendo com que haja uma sincronização entre elas e uma resposta proliferativa mais homogênea (86).

Após 48 horas fez-se uma ferida (scratch) manualmente com ponteira de pipeta de plástico amarelo $(200 \mu \mathrm{L})$ sobre a monocamada de células, lavadas com PBS e tratadas com a solução de FAED na concentração de menor citotoxicidade $(41,5 \mu \mathrm{g} / \mathrm{mL})$ e controle, ambos mantidos em meio de cultura DMEM a $2 \%$ para reduzir a possibilidade de viés de proliferação, uma vez que o soro fetal bovino pode interferir nos ligantes dos receptores de interesse (86).

A partir disso foi feito o acompanhamento fotográfico da evolução do fechamento da ferida, proporcionado pela migração celular, em intervalos periódicos nos tempos de 0,12, 24, 36, e 48 horas em um microscópio de luz invertida (Zeiss Primo Vert, Göttingen, Alemanha), equipado com câmera digital (Zeiss ERC 5s, Göttingen, Alemanha) em objetiva de 10x. As taxas relativas de 
fechamento das feridas foram medidas e expressas como porcentagem do comprimento inicial no momento zero do tratamento com o extrato em comparação com o controle. Para essa medida foram utilizadas áreas de 3 poços independentes para cada tratamento.

\subsubsection{Ensaio de Migração (Transwell Migration Assay)}

Motilidade é uma característica essencial de células vivas, estando a migração celular presente em eventos como no desenvolvimento embrionário, na resposta imunitária tecidual, e em processos inflamatórios (87). No ensaio de migração celular são obtidas quantitativamente as células que conseguem migrar por uma barreira física em direção à um estímulo quimioatrativo. Foi verificada a capacidade do extrato em alterar a migração das células de mucosa gengival através de uma membrana celular permeável, utilizando-se câmaras do tipo Transwell 6,5 milímetros (Corning Costar, Cambridge, MA, USA), contendo membranas de policarbonato com poros de $8 \mu \mathrm{m}$. As câmaras foram colocadas em placas de 24 poços contendo 600 $\mu \mathrm{L}$ de DMEM a 10\% de FBS por poço. As células foram semeadas sobre o compartimento superior da câmara ( $2 \times 10^{6}$ cel./poço) e incubadas a $37^{\circ} \mathrm{C}$ durante 24 horas. Após esse período as células foram tratadas com DMEM a $2 \%$ de SFB, adicionado a FAED que apresentou a menor citotoxicidade $(41,5 \mu \mathrm{g} / \mathrm{mL})$, e como controle negativo foi utilizado apenas DMEM a $2 \%$ de SFB.

Após 48 horas do tratamento, as células que atravessaram a membrana foram fixadas em metanol durante 20 minutos, coradas com cristal violeta $0,2 \%$ durante 15 minutos, e posteriormente lavadas com PBS por 10 vezes. Após a última lavagem, as células da porção superior do filtro (células que não migraram) foram removidas com o auxílio de um cotonete para não afetar no resultado. As membranas contendo as células coradas que migraram foram secas e suas imagens foram capturadas sob microscópio de luz (Zeiss Primo Vert, Göttingen, Alemanha), 
equipado com câmera digital (Zeiss ERC 5s, Göttingen, Alemanha). As fotomicrografias foram tomadas com ampliação de 4x para a contagem do número de células que migraram, utilizando o software de análise de imagem ZEN (Carl Zeiss Microscopia GmbH, Gottingen, Alemanha).

\subsection{ENSAIO DE DIFERENCIAÇÃO OSTEOGÊNICA}

Para verificar se a fração acetônica do extrato de Eugenia dysenterica interfere na formação de nódulos de mineralização por células dos tecidos dentários, foi usado meio indutor (MI) para diferenciação osteogênica, composto por meio $\alpha$ MEM acrescido de $10 \%$ de FBS, 10mM $\beta$-glicerofosfato (BG), 10nM de dexametasona (DEX) e $50 \mu \mathrm{g} / \mathrm{mL}$ de ácido ascórbico (AA). Para o ensaio de diferenciação osteogênica, as células foram cultivadas em placa de 12 poços na concentração de $1 \times 10^{5} \mathrm{cel} /$ poço, durante 14 e 21 dias. Foram realizados os ensaios de coloração por Vermelho de Alizarina S e Von Kossa.

\subsubsection{Coloração por Vermelho de Alizarina S}

O ensaio de coloração por Vermelho de Alizarina $S$ é empregado para visualizar estruturas calcificadas. Devido à alta afinidade do corante aos sais de cálcio, o ensaio é utilizado em cultura celular para auxiliar na identificação de depósito mineral de células estudadas. O resultado obtido é a visualização de uma estrutura com coloração avermelhada sobre a placa de cultura celular.

Para verificar se o extrato de Eugenia dysenterica interfere na formação de nódulos de mineralização por células do ligamento periodontal, após 14 e 21 dias de cultivo com meio indutor para diferenciação osteogênica, as células foram lavadas gentilmente com PBS, fixadas com formalina 10\% em PBS, durante 1 hora, à temperatura ambiente e incubadas com vermelho de alizarina $S$ a $2 \%$ (Sigma Aldrich $($ ) $), \mathrm{pH} 4.2$, durante 1 hora à temperatura ambiente, para evidenciação dos 
nódulos de mineralização. As células foram divididas em 4 grupos: Grupo Controle, utilizando meio de cultivo DMEM à 10\% FBS; Grupo FAED, tratando as células com $83 \mu \mathrm{g} / \mathrm{mL}$ de FAED; Grupo FAED+Ml, tratando as células com $83 \mu \mathrm{g} / \mathrm{mL}$ de FAED e meio indutor; e Grupo Ml, tratando apenas com o meio indutor. Os depósitos de minerais apareceram corados em vermelho.

\subsubsection{Coloração por Von Kossa}

O princípio da coloração por Von Kossa é uma reação de precipitação em que os íons de prata reagem com fosfato. A degradação fotoquímica de fosfato de prata para prata ocorre na presença de luz. Este método não é específico para o próprio cálcio, mas as placas de cultura celular são tratadas com uma solução de nitrato de prata e a prata é depositada por substituição do cálcio, e por isso pode ser visualizada com uma coloração prata metálica (88).

Para o ensaio de Von Kossa, após 21 dias, os poços foram lavados com $1 \mathrm{~mL}$ de PBS e as células foram fixadas com etanol $100 \%$ por 30 minutos em temperatura ambiente. Após, as células foram reidratadas passando pela seguinte sequência: Etanol $100 \%, 90 \%, 80 \%, 70 \%$ e $50 \%$, permanecendo por 5 minutos em cada concentração. As células foram lavadas com água destilada e acrescentado Nitrato de Prata $5 \%$ a $37^{\circ} \mathrm{C}$ por 1 hora no escuro, envolto com papel alumínio. As células foram lavadas novamente com água destilada e as placas foram expostas à luz de um negatoscópio por 24 horas até que o depósito de mineral sofresse um endurecimento e fosse evidenciado pela cor prata. Com essa coloração foi comparado o grupo controle com o grupo tratado com o extrato. 


\subsection{ANÁLISE DA ATIVIDADE ANTIMICROBIANA DA EUGENIA DYSENTERICA}

O objetivo deste estudo foi avaliar e comparar in vitro a atividade antimicrobiana de digluconato de clorexidina $0,2 \%$ e 0,12 \% combinado à 83 e 41,5 $\mu \mathrm{g}$ da fração acetônica do extrato aquoso de folhas de Eugenia dysenterica contra Candida albicans 40277, microrganismo comumente associado a candidíase oral.

\subsubsection{Condições de cultura e padronização}

A cepa de referência verificada quanto ao perfil de sensibilidade foi uma linhagem de origem American Type Culture Collection (ATCC), Candida albicans 40277. O isolado liofilizado de levedura foi ressuspendido em meio líquido Sabouraud dextrose (Himedia, Mumbai, Índia), em ambiente estéril e incubado à $28^{\circ} \mathrm{C}$ por 24 horas. Decorrido o período de ativação, foi feito uma cultura de propagação em meio inclinado, incubando-se por 24 horas à $28^{\circ} \mathrm{C}$ novamente. Então, foi realizada uma suspensão direta de colônias em $5 \mathrm{~mL}$ de solução salina estéril $0,145 \mathrm{~mol} / \mathrm{L}(8,5 \mathrm{~g} / \mathrm{L} \mathrm{NaCl}$; salina a $0,85 \%)$, ajustada com espectrofotômetro, acrescentando-se solução salina suficiente para obter a transmitância equivalente a densidade celular de uma solução-padrão da escala 0,5 de McFarland em comprimento de onda de $530 \mathrm{~nm}$. Esse procedimento fornece uma suspensãopadrão de levedura contendo $1 \times 10^{6}$ a $5 \times 10^{6}$ células por $\mathrm{mL}$. A suspensão de trabalho foi produzida fazendo-se uma diluição 1:50 seguida de uma diluição de 1:20 da suspensão-padrão com meio líquido para se obter 0 inóculo $2 X$ concentrado usado no teste (de $1 \times 10^{3}$ a $5 \times 10^{3} \mathrm{UFC} / \mathrm{mL}$ ) resultando em um inóculo de $0,5 \times 10^{3}$ a $2,5 \times 10^{3}$ unidades formadoras de colônias (UFC/mL). 


\subsubsection{Método de Difusão em Disco}

A atividade antimicrobiana do digluconato de clorexidina combinado à fração acetônica do extrato aquoso de Eugenia dysenterica foi testada na linhagem de Candida albicans, pelo método de difusão em disco. Esse método é recomendado pelo National Committee for Clinical Laboratory Standards (NCCLS), em que a concentração inibitória mínima (CIM) foi definida como a menor concentração detectada visualmente que inibiu o crescimento do microrganismo (89). Esta técnica fornece resultados qualitativos de padrão de resposta quanto à sensibilidade de cepas frente a concentrações pré-estabelecidas de uma droga antimicrobiana e, a partir desta resposta, é possível agrupar o microrganismo como sensível ou resistente (90).

Da suspensão padronizada de microrganismo, foi inoculado $100 \mu \mathrm{L}$ sobre 20 $\mathrm{mL}$ de meio de cultura sólido por meio de espalhamento em placas de petri de 90×15 $\mathrm{cm}$ de diâmetro preparadas previamente, esperando-se a completa secagem do inóculo sobre o ágar. Em seguida, dispensou-se os discos contendo as substâncias teste tomando o cuidado para uma vez depositados não movê-los mais, pois a difusão pode ser instantânea. Assim, as placas contendo leveduras receberam $1 \mathrm{x}$ $10^{3}$ a $5 \times 10^{3} \mathrm{UFC} / \mathrm{mL}$. Em seguida, foram dispensados discos papel estéril (Wattman), com 6,0 mm de diâmetro que foram impregnados com $20 \mu \mathrm{L}$ das preparações de concentrações de 0,2 e 0,12\% de digluconato de clorexidina sozinho ou associado à 83 e 41,5 $\mu \mathrm{g}$ de derivado vegetal por disco, posteriormente as placas foram invertidas e incubadas à $28^{\circ} \mathrm{C}$ durante 24 horas. Decorrido o período de incubação, o diâmetro das zonas de inibição foi mensurado em milímetros com um paquímetro. Foi considerada como CIM, a menor concentração do agente sensibilizante que inibiu o crescimento do microrganismo avaliado, pela observação da presença de halos de inibição.

Como controle positivo para os ensaios, foram empregados discos das substâncias padrão fluconazol $32 \mu \mathrm{g} /$ disco. Como controle negativo, foram utilizados discos impregnados com o solvente usado na diluição das amostras que foi a água. Todos os experimentos foram conduzidos em triplicata. Os resultados foram calculados pela média acrescido do desvio padrão dos halos produzidos pelas amostras testadas. 


\subsubsection{Método de Microdiluição em Caldo}

O método de microdiluição em caldo é considerado apropriado para monitorar quantitativamente o potencial de um agente ativo $(91,92)$.

Para o teste de microdiluição em caldo, o digluconato de clorexidina foi diluído com água ultra pura esterilizada, de forma a obter uma solução de 0,4\%, a qual foi diluída em série com concentrações finais no meio de cultura em cada poço variando de 0,2 até $0,0001 \%$. Para a fração resultante do fracionamento do extrato aquoso de Eugenia dysenterica, fez-se uma solução com uma concentração de 167 $\mu \mathrm{g} / \mathrm{mL}$ a qual foi diluída em conjunto com a solução descrita anteriormente e semelhantemente testada a concentrações que foram de 0,04 até $83 \mu \mathrm{g} / \mathrm{mL}$.

O perfil de susceptibilidade das amostras foi verificado utilizando-se microplacas com 96 poços, com volume de $100 \mu \mathrm{L}$ de meio de cultura líquido contendo o inóculo padronizado 2x concentrado ao qual foi adicionado $100 \mu \mathrm{L}$ das amostras avaliadas procedendo-se uma diluição seriada e obtendo-se assim concentrações decrescentes.

Poços contendo apenas meio de cultura líquido e o inóculo foram preparados para possibilitar o controle da viabilidade dos microrganismos. Além deste, também foi acrescentado poços de esterilidade, sendo utilizados poços contendo apenas o meio de cultura estéril. Para o controle positivo utilizou-se fluconazol nas concentrações de 800 até $0,39 \mu \mathrm{g} / \mathrm{mL}$.

As placas foram incubadas por 24 horas em estufa à $28^{\circ} \mathrm{C}$. Cumprido o período de incubação, aos poços foram adicionados $30 \mu \mathrm{L}$ de Resazurina (SigmaAldrich) a $0,01 \%$ e, após $4 \mathrm{~h}$ de reincubação, foi realizada leitura visualmente. A presença ou ausência de crescimento microbiano foi revelada por meio deste ensaio colorimétrico; sendo demonstrada resposta positiva de atividade por meio da coloração roxa, que indica a ausência de células viáveis, e resposta negativa de atividade por meio da coloração amarela, que indica presença de células viáveis. Para cada teste foram realizados ensaios em triplicata. Este indicador é reduzido a resofurina, que ao reagir promove coloração rosa demonstrando que há viabilidade 
celular e quando não ocorre reação permanece azul indicando inexistência de metabolismo celular (93). Além disso, este método colorimétrico tem a vantagem de permitir leitura diretamente visual, além de ser um método de baixo custo, fácil e reproduzível (94).

\subsection{ANÁLISE ESTATÍSTICA}

A análise estatística foi realizada em oitoplicatas independentes para os testes de citotoxicidade e em triplicatas independentes para os demais experimentos. Os resultados de citotoxicidade, viabilidade e proliferação celular foram analisados por meio de análise de variância (ANOVA), seguida do teste de comparação múltipla de Tukey's. Para a análise da migração celular foi optou-se por aplicar o test $T$ de Student. Todos os testes estatísticos foram realizados com o programa GraphPad versão 5.0 para Windows. O critério de significância será o valor $p<0,05$. 


\section{RESULTADOS}

\subsection{CITOTOXICIDADE DO EXTRATO DE EUGENIA DYSENTERICA EM CÉLULAS DE MUCOSA GENGIVAL}

Após 24, 48 e 72 horas de tratamento das células de mucosa gengival com o extrato bruto e fração acetônica de extrato bruto de Eugenia dysenterica, e as três concentrações de células por poço, foi realizado o teste de citotoxicidade celular. A concentração que apresentou o melhor resultado de viabilidade celular foi a concentração de $1 \times 10^{4}$ cél/poço. Além disso, foi determinado que a fração acetônica do extrato apresentava menor citotoxicidade, quando comparado ao tratamento com o extrato bruto. Ainda, como resultado, a concentração de $83 \mu \mathrm{g} / \mathrm{mL}$ de fração acetônica apresentou menor citotoxicidade quando comparada com a concentração de $167 \mu \mathrm{g} / \mathrm{mL}$.

Todos os resultados com o extrato bruto de Eugenia dysenterica e todos os resultados com a concentração de $167 \mu \mathrm{g} / \mathrm{mL}$ apresentaram elevada toxicidade às células gengivais e de ligamento periodontal. Por esse motivo, foram excluídos os testes com este tipo de extrato e com essa concentração.

Dentre as nove concentrações testadas, apenas as concentrações de $20,75 \mu \mathrm{g} / \mathrm{mL}$ e $41,5 \mu \mathrm{g} / \mathrm{mL}$ em 24 e 48 horas resultaram em aumento da viabilidade celular comparadas ao grupo controle (Figura 5 e 6). Todas as outras sete concentrações não apresentaram toxicidade celular em 24 e 48 horas. Em 72 horas todas as concentrações não demonstraram citotoxicidade, exceto a concentração de $83 \mu \mathrm{g} / \mathrm{mL}$ que apresentou toxicidade, reduzindo a viabilidade das células de mucosa gengival para $60 \%$ (Figura 7 ). Apesar de todos os extratos testados não serem citotóxicos após 72 horas de tratamento, esses resultados não foram estatisticamente significantes e por isso não podemos dizer que a ação citotóxica é tempo-dependente. $O$ tratamento com a concentração de $41,5 \mu \mathrm{g} / \mathrm{mL}$ em 48 horas 
resultou em aumento celular de $31 \%$ comparado ao grupo controle e foi estatisticamente significante $(p<0,05)$. Esses dados da porcentagem de viabilidade celular podem ser observados na tabela 01.

Tabela 1. Avaliação da atividade citotóxica de nove concentrações de fração acetônica de extrato de Eugenia dysenterica em linhagem celular de mucosa gengival.

\begin{tabular}{cccc}
\hline Concentrações & \multicolumn{3}{c}{ Células Viáveis (\%) } \\
\cline { 2 - 4 } (FAED) $\boldsymbol{\mu g} / \mathbf{m L}$ & $\mathbf{2 4}$ horas & $\mathbf{4 8}$ horas & $\mathbf{7 2}$ horas \\
0,25 & 78,8 & 94,2 & 78,2 \\
0,5 & 80,7 & 90,3 & 72,5 \\
1,0 & 81,0 & 96,5 & 79,1 \\
2,0 & 88,0 & 91,1 & 76,6 \\
4,1 & 91,0 & 95,5 & 80,4 \\
8,3 & 87,2 & 94,4 & 79,9 \\
20,75 & 99,0 & 112,1 & 82,4 \\
41,5 & 102,9 & $131,0 *$ & 84,4 \\
83 & 82,0 & 84,9 & 60,6 \\
\hline
\end{tabular}

Os resultados representam a média de células viáveis tratadas com a concentrações de fração acetônica do extrato. ( ${ }^{*} \mathrm{p}<0,05$ versus controle; teste One-way ANOVA, Postest Turkey's). 


\section{MTT de células gengivais (24 horas)}

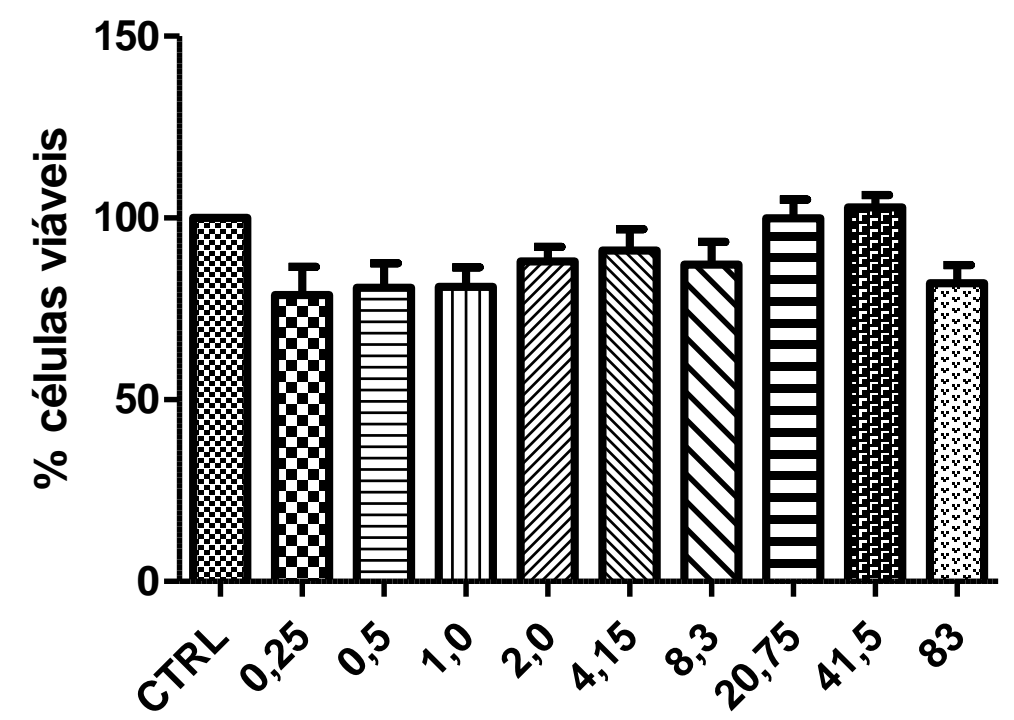

Concentrações Fração Acetônica de Eugenia dysenterica $(\mu \mathrm{g} / \mathrm{mL})$

Figura 5. Avaliação do efeito citotóxico de nove concentrações de fração acetônica de Eugenia dysenterica em células de mucosa gengival em 24 horas. $C T R L=$ controle.

\section{MTT de células gengivais (48 horas)}

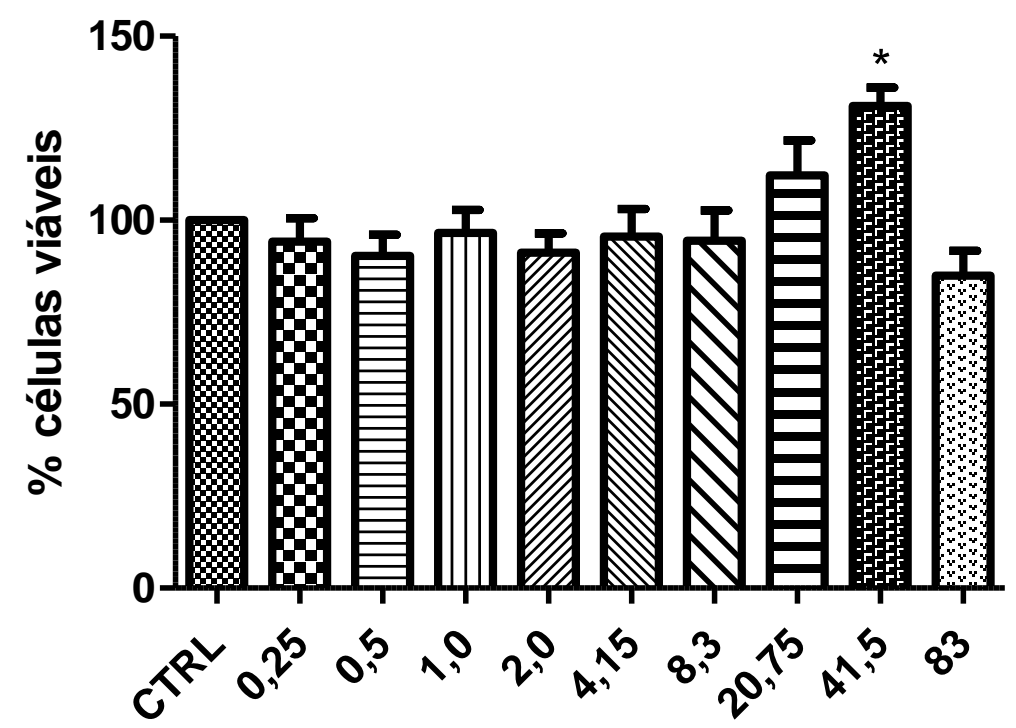

Concentrações Fração Acetônica de Eugenia dysenterica $(\mu \mathrm{g} / \mathrm{mL})$

Figura 6. Avaliação do efeito citotóxico de nove concentrações de fração acetônica de Eugenia dysenterica em células de mucosa gengival em 48 horas. CTRL $=$ controle. ( ${ }^{*} p<0,05$ versus controle; teste One-way ANOVA, Postest Turkey's). 


\section{MTT de células gengivais (72 horas)}

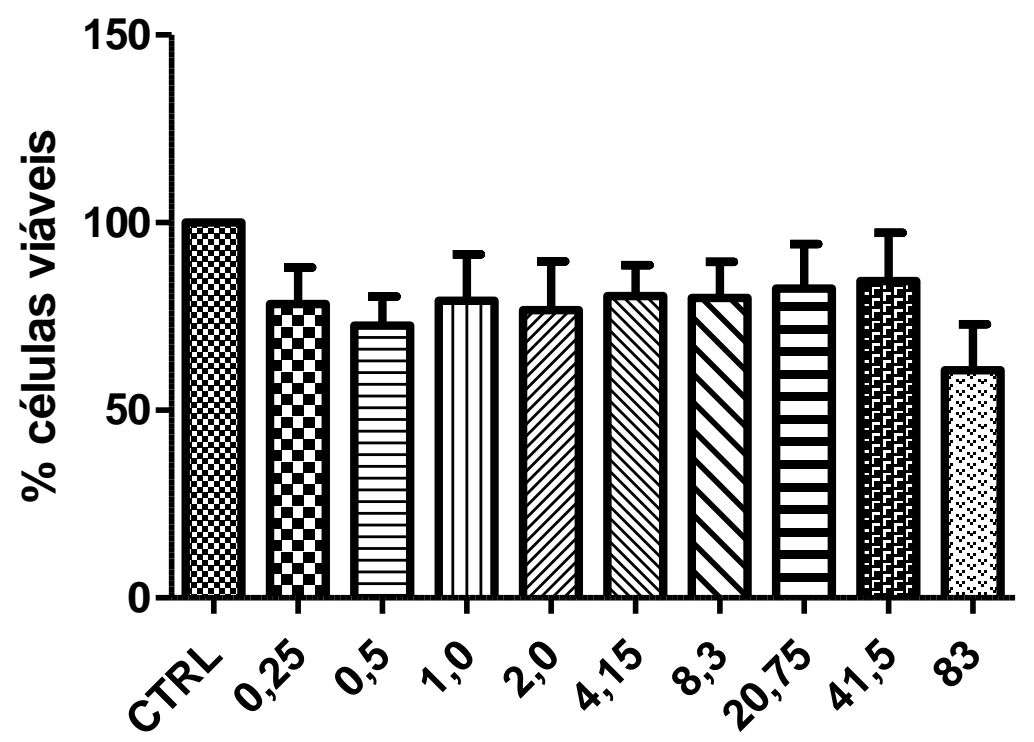

Concentrações Fração Acetônica de Eugenia dysenterica $(\mu \mathrm{g} / \mathrm{mL})$

Figura 7. Avaliação do efeito citotóxico de nove concentrações de fração acetônica de Eugenia dysenterica em células de mucosa gengival em 72 horas. $C T R L=$ controle. 
5.2 AVALIAÇÃO DA CITOTOXICIDADE INDUZIDA PELA FRAÇÃO ACETÔNICA COMPARADA COM O DIGLUCONATO DE CLOREXIDINA NAS LINHAGENS DE MUCOSA GENGIVAL.

Após 24 e 48 horas do tratamento das células, o resultado do MTT evidenciou como estatisticamente significante a alta toxicidade da $\mathrm{CHX}$ comparadas com 0 grupo controle, enquanto a FAED apresentou baixa toxicidade $(p<0,05)$ (Figura 8). Após 72 horas tanto a $\mathrm{CHX}$ quanto a FAED apresentaram resultados estatisticamente significantes com alta toxicidade em ambos $(p<0,05)$, sendo, após esse tempo, a FAED mais tóxica que a $\mathrm{CHX}$ para as células gengivais. Além desses dados, foi observado também como resultado o aumento da viabilidade celular quando associado FAED e CHX. Em 24, 48 e 72 horas, foi observada a baixa toxicidade da associação das soluções quando comparado com o controle negativo, controle positivo e a FAED isolada. Esses dados foram estatisticamente significativos em 72 horas, e em 48 horas entre a associação de FAED e CHX 0,2\% $(p<0,05)$, sendo visto, portanto, que a FAED diminui a toxicidade da $\mathrm{CHX}$ (Figura 8). Os resultados são representados pelos gráficos da figura 8 .

Tabela 2. Avaliação da atividade citotóxica de FAED à $41,5 \mu \mathrm{g} / \mathrm{mL}$ e digluconato de clorexidina $(\mathrm{CHX})$ em células de mucosa gengival.

\begin{tabular}{cccc}
\hline \multirow{2}{*}{ Concentrações } & \multicolumn{3}{c}{ Células Viáveis (\%) } \\
\cline { 2 - 4 } FAED 41,5 $\mu \mathrm{g} / \mathrm{mL}$ & $55,7^{*}$ & $\mathbf{4 8}$ horas & $\mathbf{7 2}$ horas \\
CHX 0,12\% & $46,9^{*}$ & $39,4^{*}$ & $32,3^{*}$ \\
CHX 0,2\% & $43,5^{*}$ & $43,1^{*}$ & $37,2^{*}$ \\
FAED + CHX 0,12\% & 75,7 & 78,9 & $43,5^{*}$ \\
FAED + CHX 0,2\% & 76,5 & $67,6^{*}$ & $66,0^{*}$ \\
\hline
\end{tabular}

Os resultados representam a média de células viáveis tratadas com FAED, CHX e a associação das duas soluções em células de mucosa gengival $\left({ }^{*} p<0,05\right.$ versus controle; teste One-way ANOVA, Postest Turkey's). 

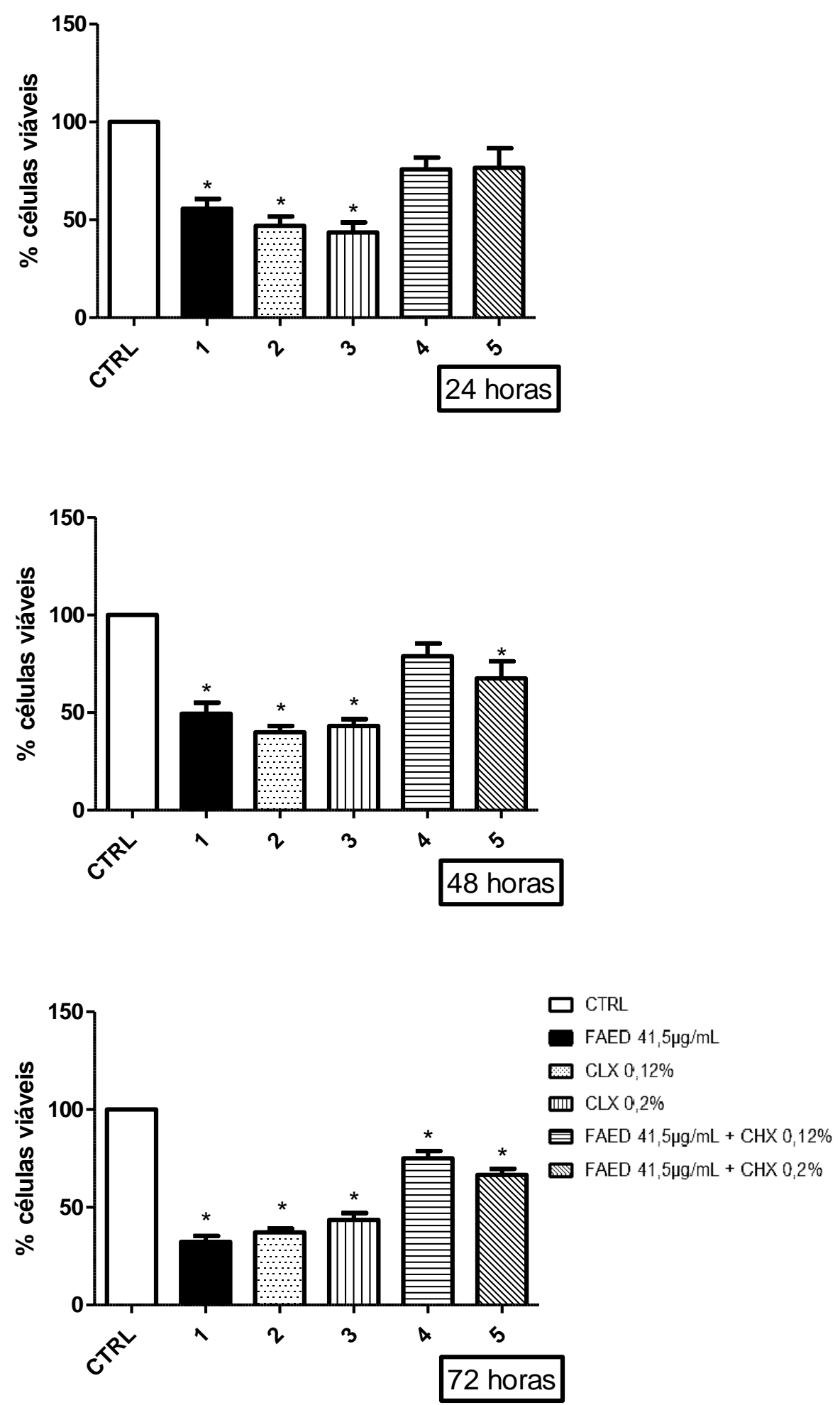

Figura 8. Efeito citotóxico de FAED e CHX em células de mucosa gengival. CTRL: controle DMEM 2\%; 1: FAED 41,5 $\mu \mathrm{g} / \mathrm{mL}$ + DMEM 2\%; 2: CHX 0,12\% + DMEM 2\%; 3: CHX 0,2\% + DMEM 2\%; 4:

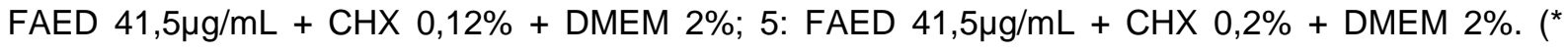
$\mathrm{p}<0,05$ versus controle; teste One-way ANOVA, Postest Turkey's) 


\subsection{CITOTOXICIDADE DA FAED EM CÉLULAS DE LIGAMENTO PERIODONTAL}

Foi realizado o ensaio de MTT com as células de ligamento periodontal utilizando a concentração de $83 \mu \mathrm{g} / \mathrm{mL}$ de FAED como tratamento para o tempo de 24 horas. Sugere-se que a FAED não tenha apresentado toxicidade às células de ligamento periodontal, no entanto, tal ensaio não foi estatisticamente significante (Figura 9).

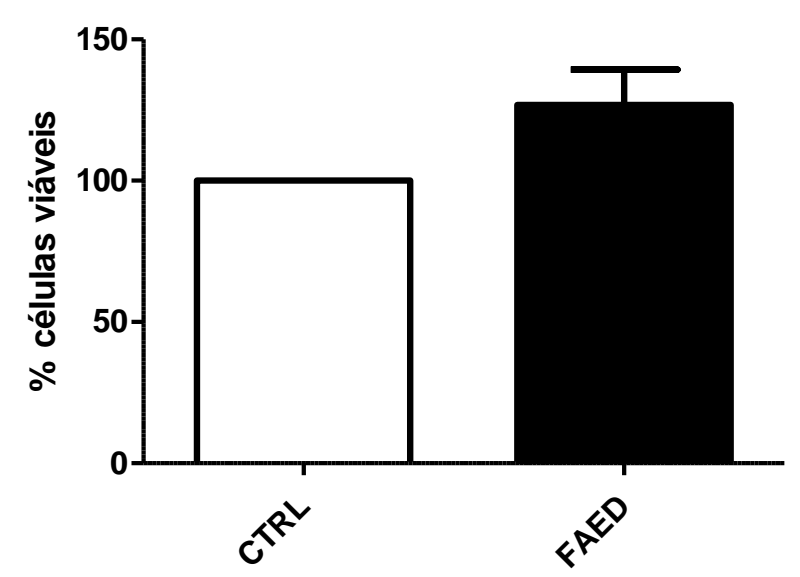

Figura 9. Avaliação do efeito citotóxico de FAED $83 \mu \mathrm{g} / \mathrm{mL}$ em 24 horas. CTRL = Controle; FAED = Fração acetônica de Eugenia dysenterica à $83 \mu \mathrm{g} / \mathrm{mL}$.

Outro ensaio de MTT, ainda com a linhagem de células do ligamento periodontal, foi realizado utilizando as concentrações de $8,3 \mu \mathrm{g} / \mathrm{mL}, 20,75 \mu \mathrm{g} / \mathrm{mL}$, $41,5 \mu \mathrm{g} / \mathrm{mL}$ e $83 \mu \mathrm{g} / \mathrm{mL}$ de FAED em 24 horas de tratamento. Os resultados sugerem que a concentração de $8,3 \mu \mathrm{g} / \mathrm{mL}$ não causa citotoxicidade para as células do ligamento periodontal, porém, a única dosagem que apresentou resultado estatisticamente significativo foi a concentração de $83 \mu \mathrm{g} / \mathrm{mL}$ (Figura 10). Essa concentração apresentou baixa citotoxicidade com $74,8 \%$ de células viáveis. As

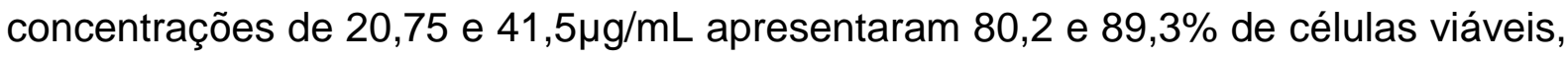
respectivamente. 


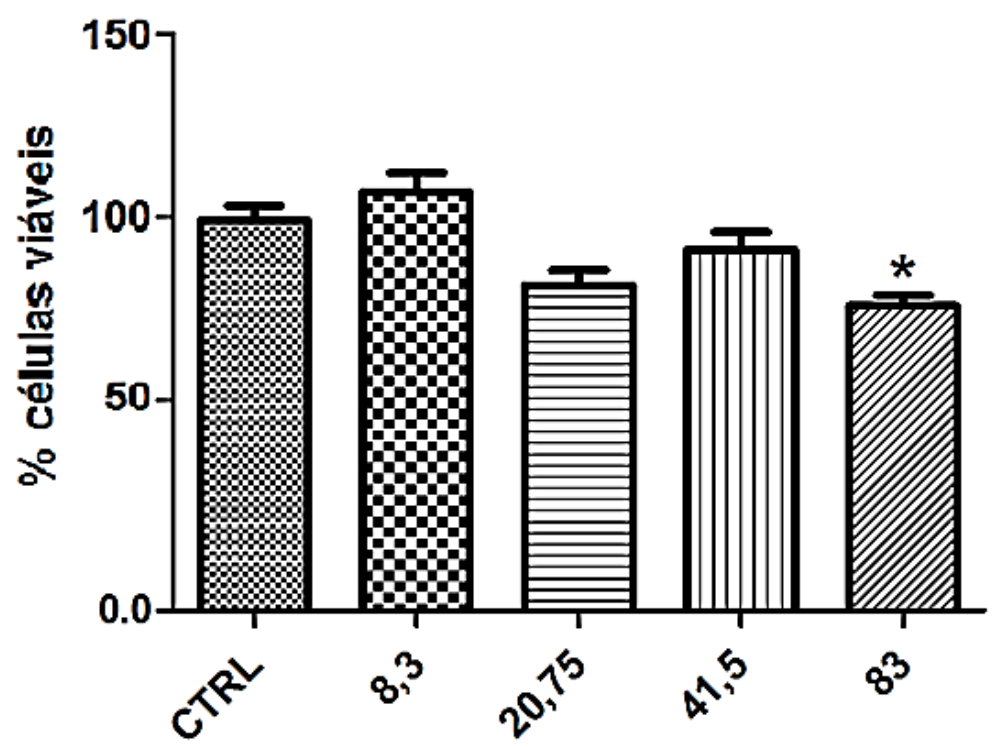

Concentrações Fração Acetônica de Eugenia dysenterica $(\mu \mathrm{g} / \mathrm{mL})$

Figura 10. Avaliação do efeito citotóxico de FAED em células do ligamento periodontal. $C T R L=$ controle $\left({ }^{*} p<0,05\right.$ versus controle; teste One-way ANOVA, Postest Turkey's).

5.4 MORFOLOGIA CELULAR DE CÉLULAS DA MUCOSA GENGIVAL E LIGAMENTO PERIODONTAL TRATADAS COM FAED

Em aumento de 10x foi observado que quanto maior o tempo de exposição das células à Eugenia dysenterica, maior a alteração da morfologia celular (Figura 11). No aumento de 20x, 48 horas após o tratamento, observou-se o início de alterações morfológicas celulares, com a presença de vacúolos, como demonstra a figura 12. Nela observamos a retração celular, com perda de aderência com as células vizinhas, e o núcleo se desintegrando em fragmentos. 


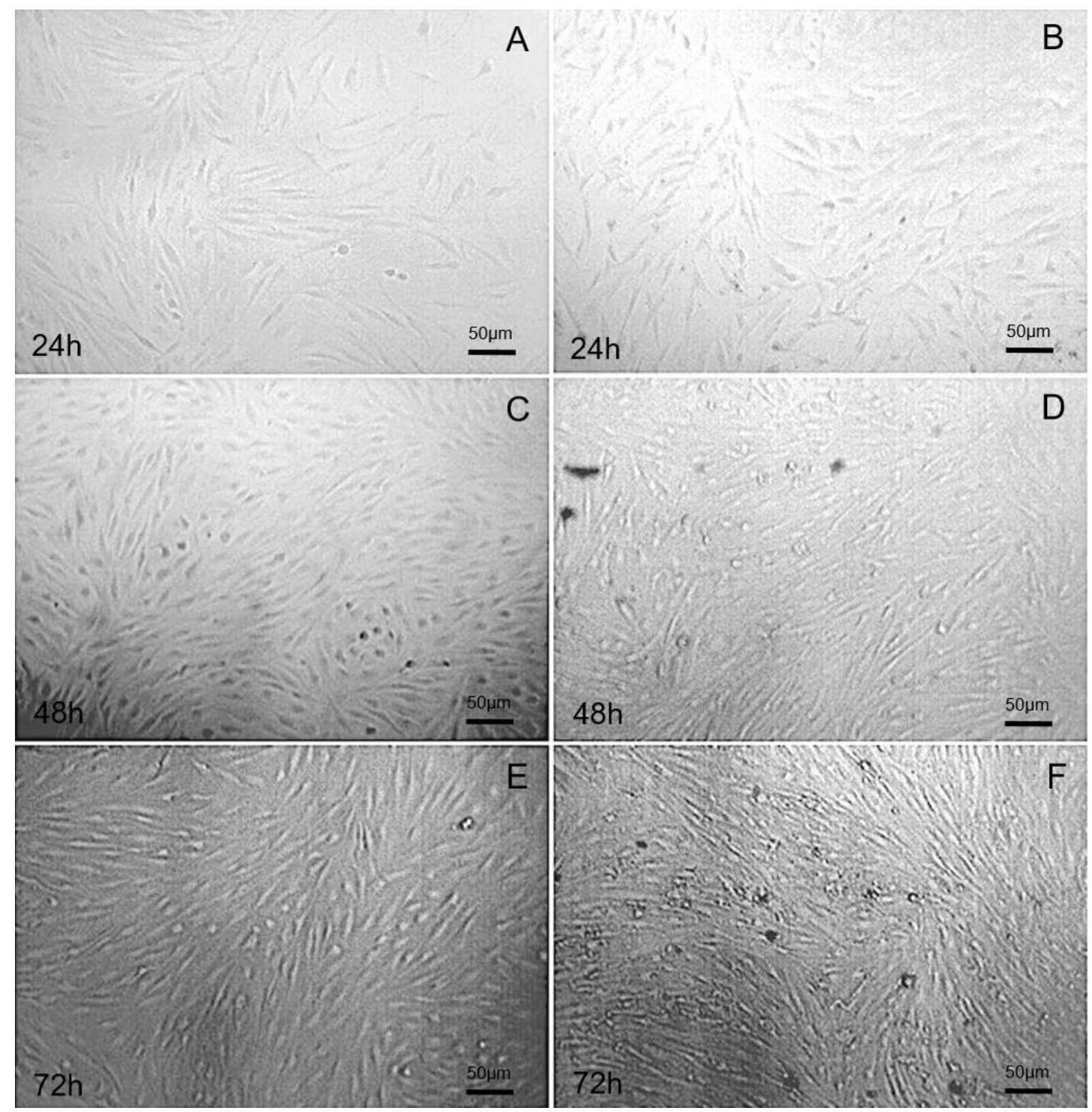

Figura 11. Morfologia de células de mucosa gengival tratadas com FAED na concentração de $41,5 \mu \mathrm{g} / \mathrm{mL}$. A, C e E: células do grupo controle com aspecto morfológico normal. B, D e F: células tratadas com a FAED com alterações morfológicas comparadas ao grupo controle. 


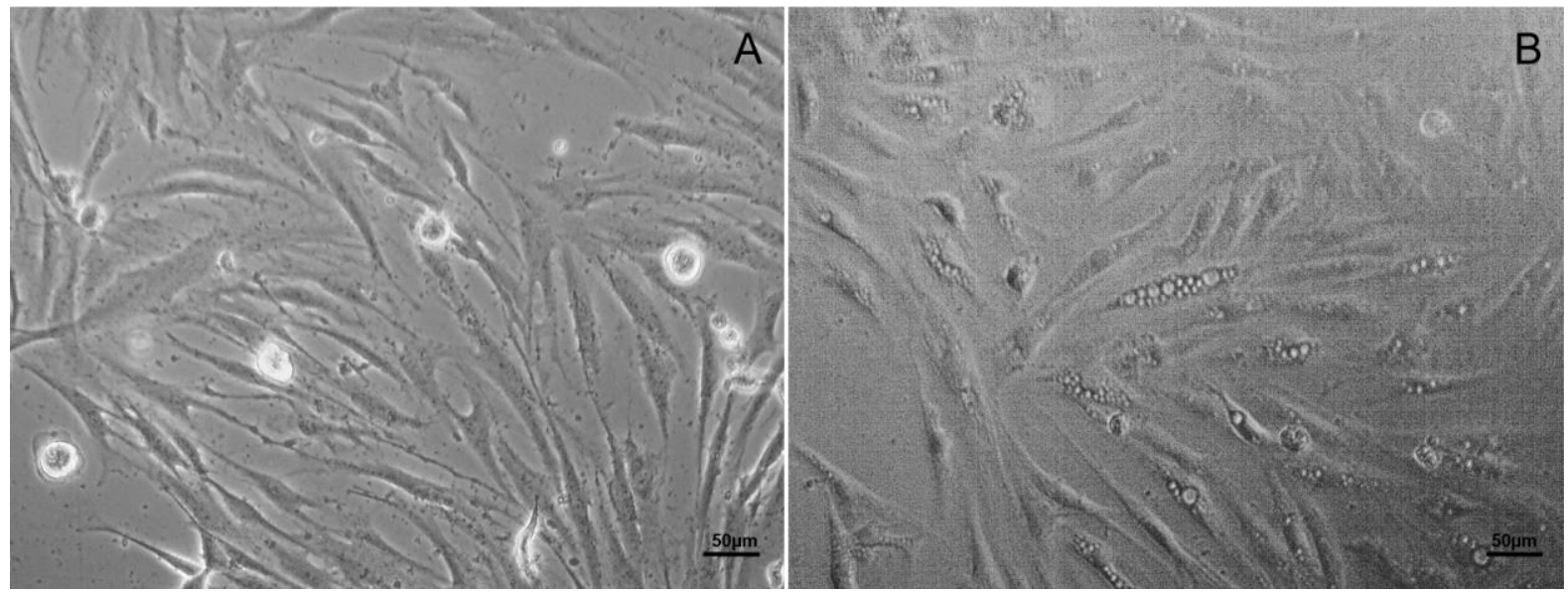

Figura 12. Efeito de $41,5 \mu \mathrm{g} / \mathrm{mL}$ da fração acetônica de extrato de Eugenia dysenterica em células de mucosa gengival após 48 horas. A: Células do grupo controle sem alterações morfológicas. B: Células de mucosa gengival tratadas com a FAED. Observa-se a retração celular, perda da adesão celular e presença de vacúolos.

Os resultados da análise morfológica foram semelhantes as relatadas com as células gengivais. Com o passar do tempo as células apresentaram alterações morfológicas e presença de vacúolos no interior do citoplasma (Figura 13). A figura 13J mostra as células expostas ao tratamento após 21 dias, e muitas parecem consistir exclusivamente de uma forma densa, de núcleos com coloração escura. As células não mantem suas ligações intercelulares e perdem o aspecto fusiforme, dando lugar às células com aspecto esférico. 


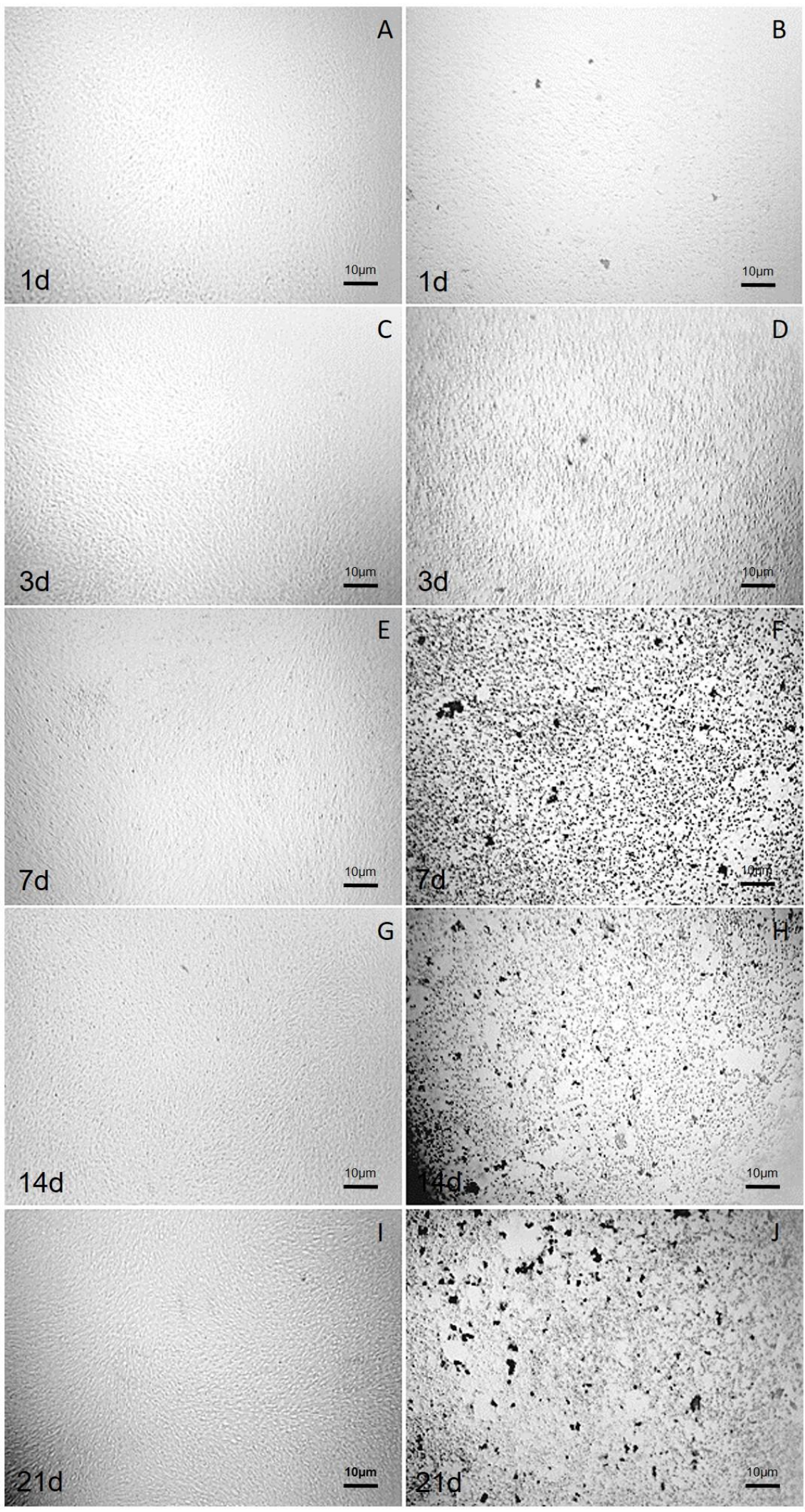

Figura 13. Morfologia das células de ligamento periodontal tratadas com FAED $(83 \mu \mathrm{g} / \mathrm{mL})$. A, C, E, G, I: grupo controle com aspecto morfológico normal; B, D, F, H, $\mathrm{J}$ : grupo tratado com a FAED, observar a perda de ligações intercelulares e células alterando 0 aspecto fusiforme para uma morfologia celular esférica. 


\subsection{AVALIAÇÃO DO FECHAMENTO DA FERIDA (SCRATCH)}

O teste de fechamento de ferida demonstrou que nas horas iniciais, 0 tratamento com $41,5 \mu \mathrm{g} / \mathrm{mL}$ de FAED influenciou o processo de migração celular evitando com que as linhagens de gengiva migrassem e fossem capazes de fechar a ferida aberta na placa (Figura 14). Em 12 horas pós-tratamento, nas células controle houve $10 \%$ a mais de área fechada do que nas células tratadas com FAED. Após 24 horas de tratamento houve fechamento de $60 \%$ da ferida no grupo controle e $40 \%$ no grupo da FAED, ou seja, o grupo controle apresentou $20 \%$ a mais de fechamento da ferida. Com 36 horas, essa porcentagem aumenta, chegando a $30 \%$ de diferença, com o grupo controle praticamente fechando a ferida. Após 48 horas, nas feridas do grupo controle já não era possível identificar as margens de maneira clara, determinando então o fechamento total da ferida. No entanto, o grupo tratado com a FAED ainda faltava mais de $20 \%$ para que se completasse o fechamento da ferida (Figura 15). Dessa forma, o extrato se mostrou capaz de influenciar a capacidade das células gengivais em migrar para o fechamento de uma lesão. 

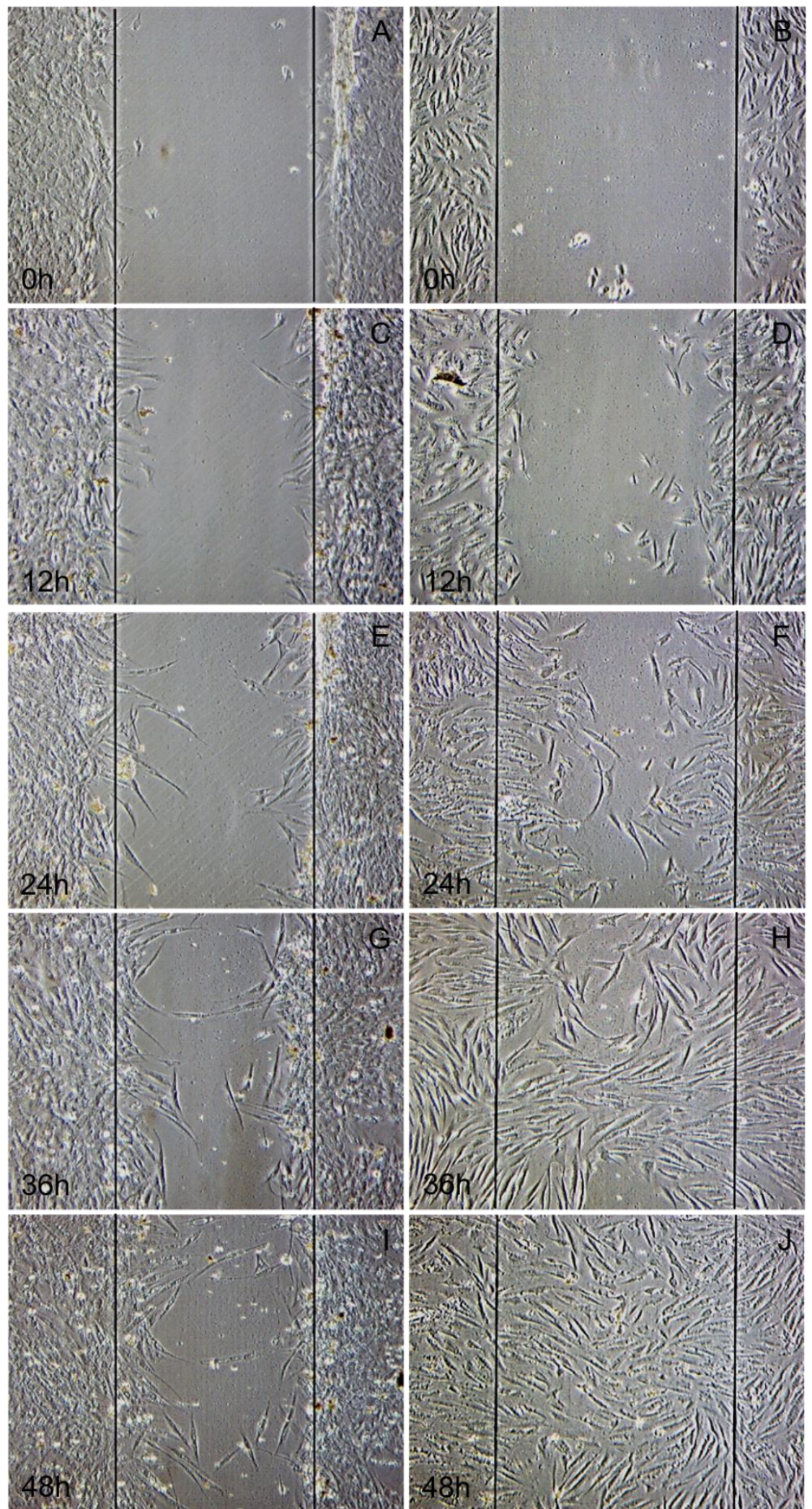

Figura 14. Avaliação do fechamento de lesão em monocamada de células gengivais tratamentas com FAED. A, C, E, G, I: Células do grupo controle, tratadas com DMEM 2\%FBS; observar fechamento total da ferida em 48 horas. B, D, F, H, J: Células do grupo FAED, tratadas com DMEM $2 \% F B S$ e $41,5 \mu \mathrm{g} / \mathrm{mL}$ de $\mathrm{FAED}$, não apresentando fechamento da ferida comparado ao grupo controle. 


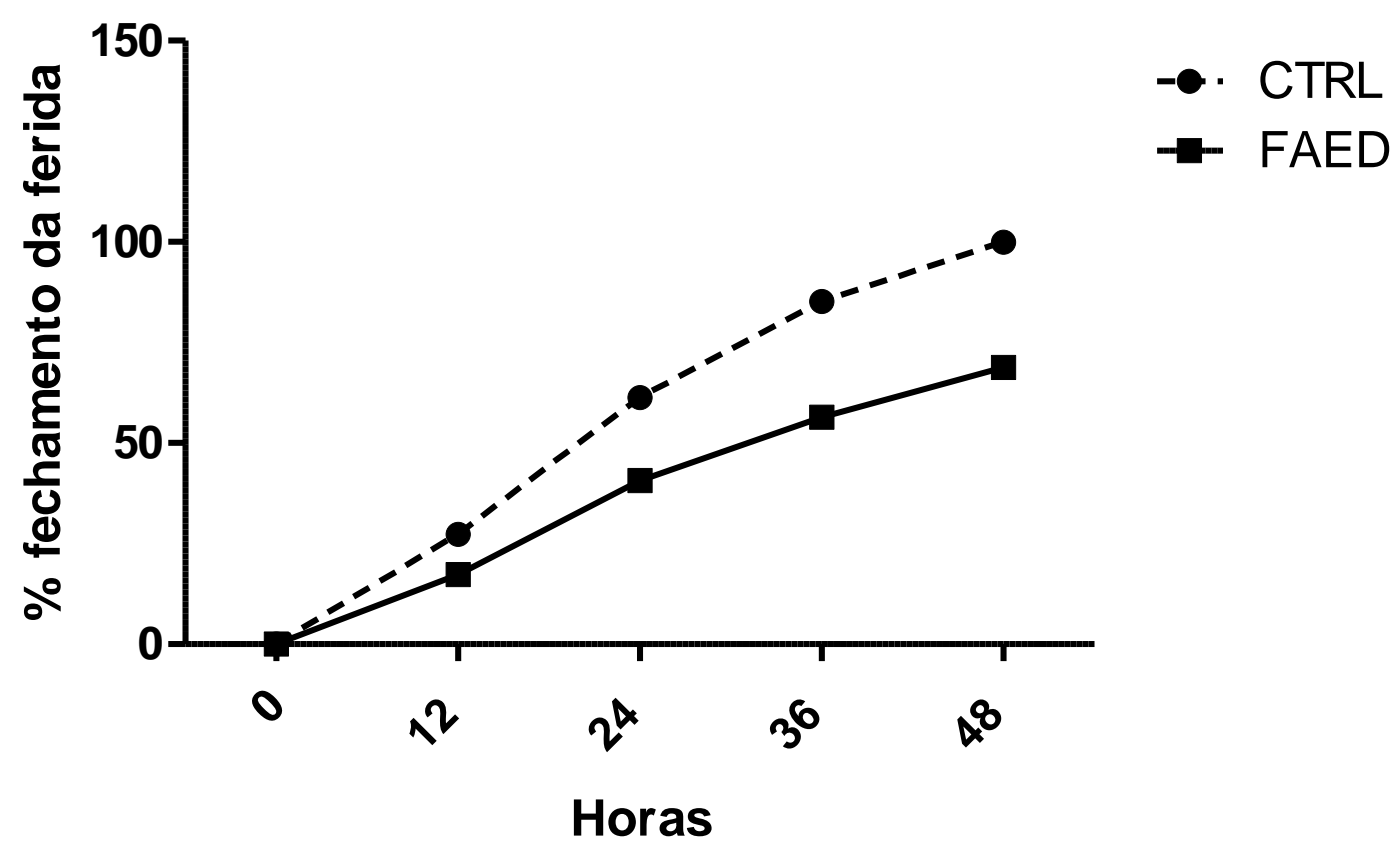

Figura 15. Cálculo do tamanho da área da ferida expresso em porcentagem. CTRL: Grupo controle; FAED: Grupo tratado com $41,5 \mu \mathrm{g} / \mathrm{mL}$ de fração acetônica do extrato de Eugenia dysenterica.

\subsection{AVALIAÇÃO DA MIGRAÇÃO CELULAR (TRANSWELL)}

Ao aplicar o teste de migração celular em 48 horas a FAED apresentou ser capaz de influenciar negativamente na capacidade das células de mucosa gengival atravessarem o compartimento superior da câmara pela membrana. Houve redução de aproximadamente $45 \%$ na migração celular (Figura 16). Esse resultado sugere que 0 a FAED pode fazer com que as células individuais não respondam ao processo de migração, diminuindo a motilidade e caráter invasivo das células, impedindo a passagem voluntária das células de um lado para o outro do filtro. A FAED não resultou como um quimiotático celular, não favorecendo as células de mucosa gengival a ultrapassar a barreira física, diminuindo a quantidade de células a ultrapassar o filtro. 


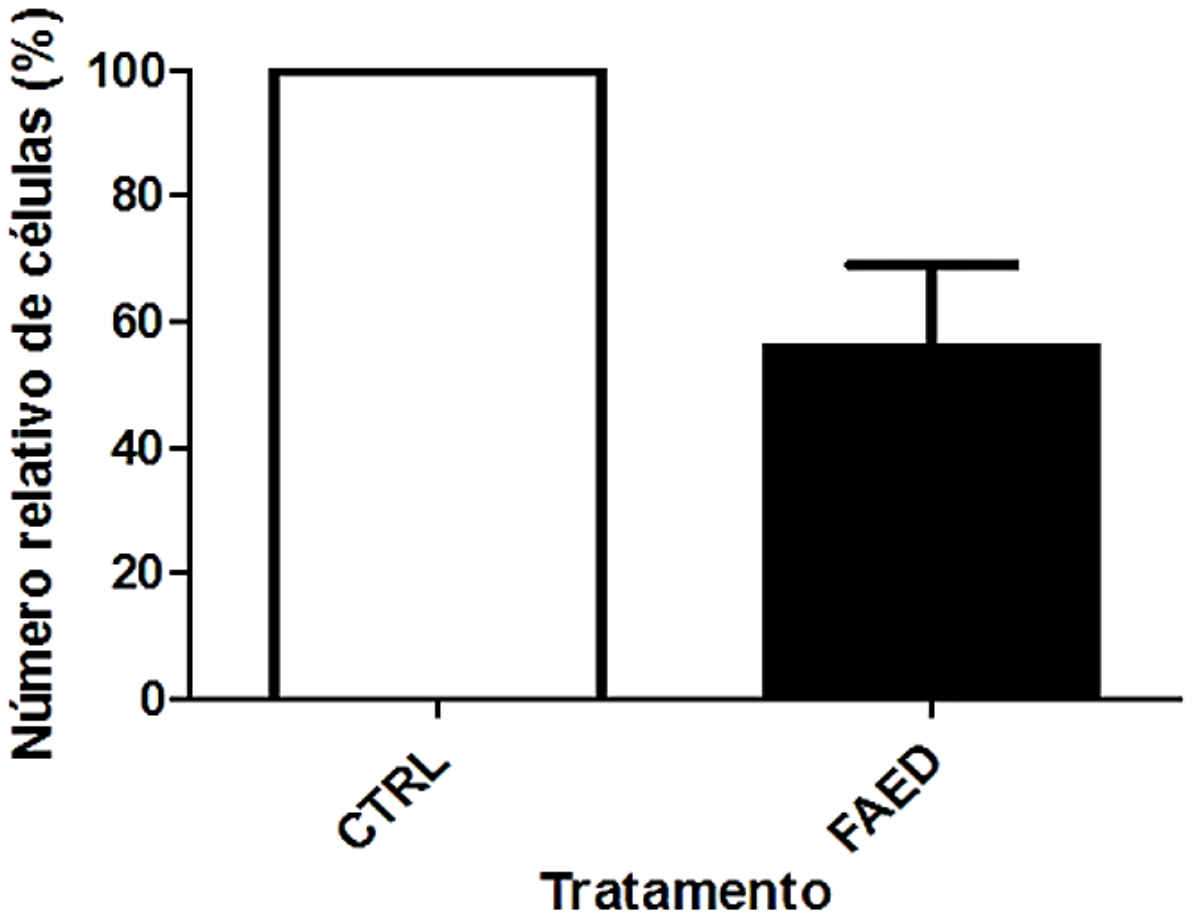

Figura 16. Percentual de células de mucosa gengival que migraram pela membrana Transwell, tratadas ou não com $41,5 \mu \mathrm{g} / \mathrm{mL}$ de FAED. CTRL: Grupo controle. 


\subsection{AVALIAÇÃO DO POTENCIAL DE MINERALIZAÇÃO DAS CÉLULAS DO LIGAMENTO PERIODONTAL}

Após 14 dias de tratamento, as células induzidas por Ml apresentaram intensa coloração avermelhada, o que indica a formação e depósito de mineral e confirmação do potencial das linhagens celulares em produzir este mineral (Figura 17D). As células tratadas com $83 \mu \mathrm{g} / \mathrm{mL}$ de FAED não apresentaram coloração e portanto não houve potencial osteogênico do extrato para as células de ligamento periodontal (Figura 17B).

Para avaliar se a FAED potencializaria a ação osteoindutora do $\mathrm{Ml}$, foi também testado os dois em conjunto. $O$ resultado mostrou a não formação de depósito de mineral e, portanto, não houve resultado positivo com o acréscimo da FAED no meio indutor, sugerindo a morte celular e, por consequência, a inibição de diferenciação osteogênica promovida pela ação do MI no período de 14 dias (Figura 17C).

Com 21 dias de tratamento foi realizado novamente o teste com Vermelho de Alizarina $S$ e foi observado diferença com os resultados de 14 dias apenas no grupo FAED+MI. O grupo controle e FAED não apresentaram depósito de mineral (Figura 18A e 18B), ao passo que houve intensa coloração no grupo MI (Figura 18D). Já o grupo FAED+Ml teve comportamento diferente ao ser tratado por mais 7 dias. Como visto na figura $18 \mathrm{C}$, houve formação de depósito mineral, no entanto, com uma intensidade de coloração avermelhada menor que o grupo Ml. 


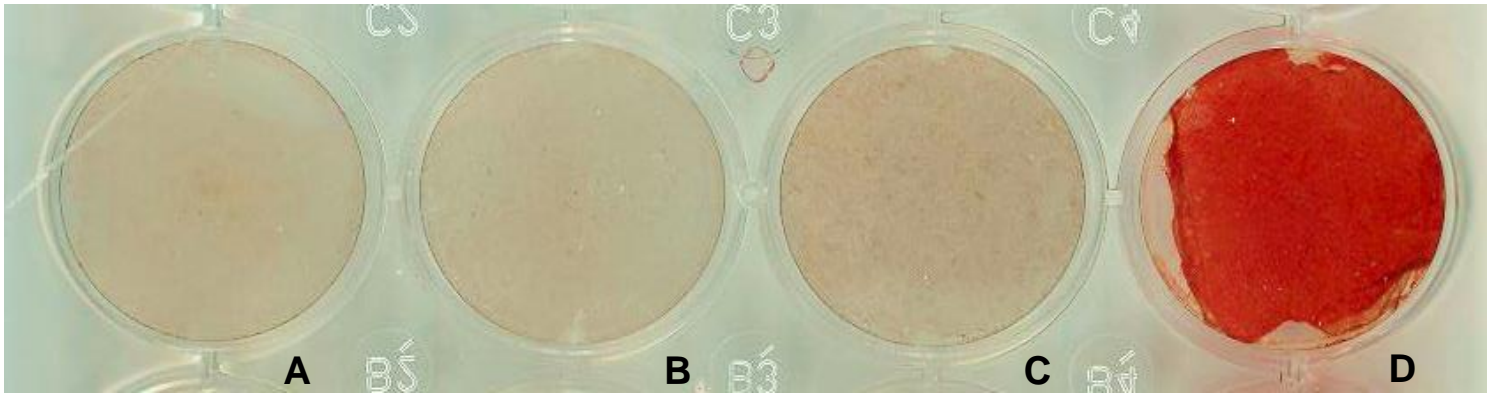

Figura 17. Avaliação colorimétrica por Vermelho de Alizarina $S$ da FAED na mineralização do ligamento periodontal em 14 dias. $A=$ Controle ( $\alpha$-MEM 10\%); B = FAED ( $\alpha$-MEM 10\% + FAED $83 \mu \mathrm{g} / \mathrm{mL}) ; \mathrm{C}=\mathrm{FAED}+\mathrm{Ml}(\alpha-M E M 10 \%+$ FAED $83 \mu \mathrm{g} / \mathrm{mL}+\mathrm{AA}+\mathrm{BG}+\mathrm{DEX})) ; \mathrm{D}=\mathrm{Ml}(\alpha-M E M$ $10 \%+A A+B G+D E X)$.
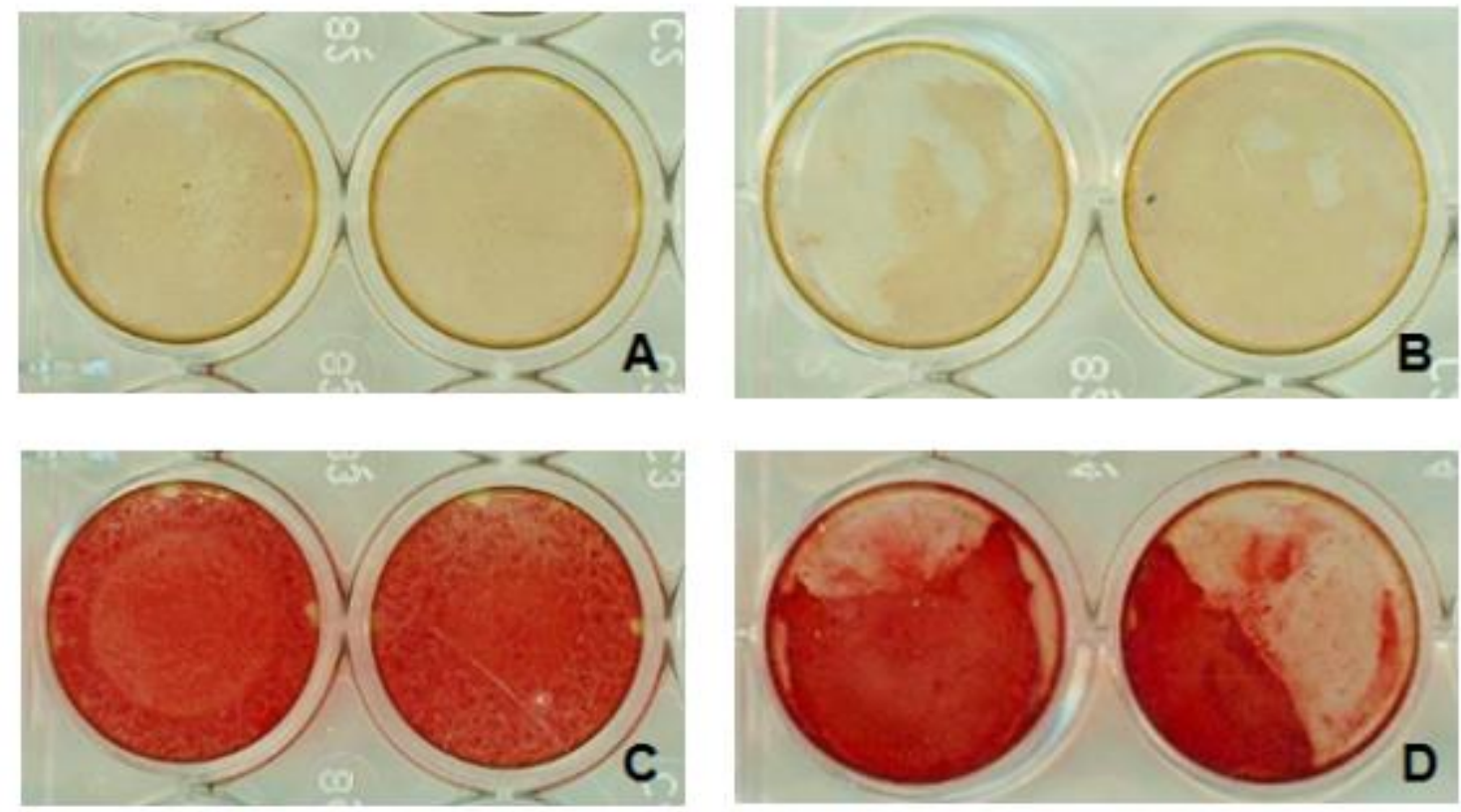

Figura 18. Avaliação colorimétrica por Vermelho de Alizarina $S$ da FAED na mineralização do ligamento periodontal em 21 dias. $A=$ Controle; $B=F A E D ; C=F A E D+M I ; D=M I$. 
Com 21 dias de tratamento foi também realizado o teste colorimétrico por Von Kossa. Os resultados confirmaram os achados com o de Vermelho de Alizarina S. O grupo controle e FAED não apresentaram mineralização (Figuras 19A e 19B), o grupo MI foi corado com a cor cinza, revelando o depósito de mineral (Figura 19C), e o grupo FAED+MI demonstrou leve coloração, o que indica também uma inibição do potencial osteogênico do MI (Figura 19D) como visto pelo teste com vermelho de alizarina S.

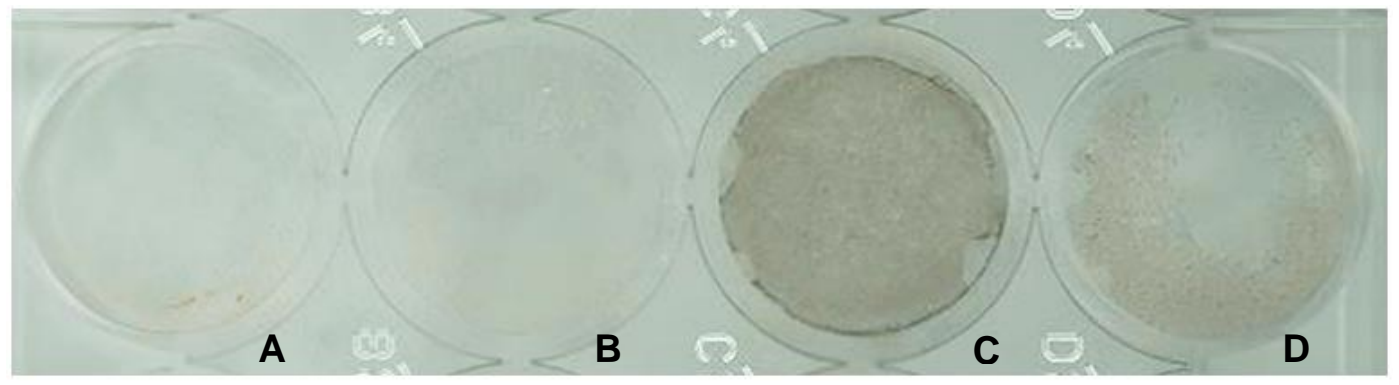

Figura 19. Avaliação colorimétrica por Von Kossa do efeito de FAED na mineralização do ligamento periodontal em 21 dias. $A=$ Controle; $B=F A E D ; C=M I ; D=F A E D+M I$. 


\subsection{AVALIAÇÃO DA ATIVIDADE ANTIMICROBIANA DA EUGENIA DYSENTERICA}

Foi avaliada a eficiência da ação antimicrobiana do digluconato de clorexidina combinado com a fração acetônica de Eugenia dysenterica frente uma linhagem de Candida albicans, verificando o perfil de sensibilidade da cepa em relação à possível sinergia entre as mostras verificadas como agente para eliminação destes microrganismos in vitro. $\mathrm{Na}$ análise do microrganismo Candida albicans, pelo método de difusão em disco não foi observada nenhuma sensibilização tanto por parte de digluconato de clorexidina como pela sua combinação com a FAED, demonstrando que a cepa não é sensível a estes agentes, porém, o agente antifúngico fluconazol promoveu halos de 27,2 mm demonstrando a sensibilização do patógeno (Figuras 20A e 20B).
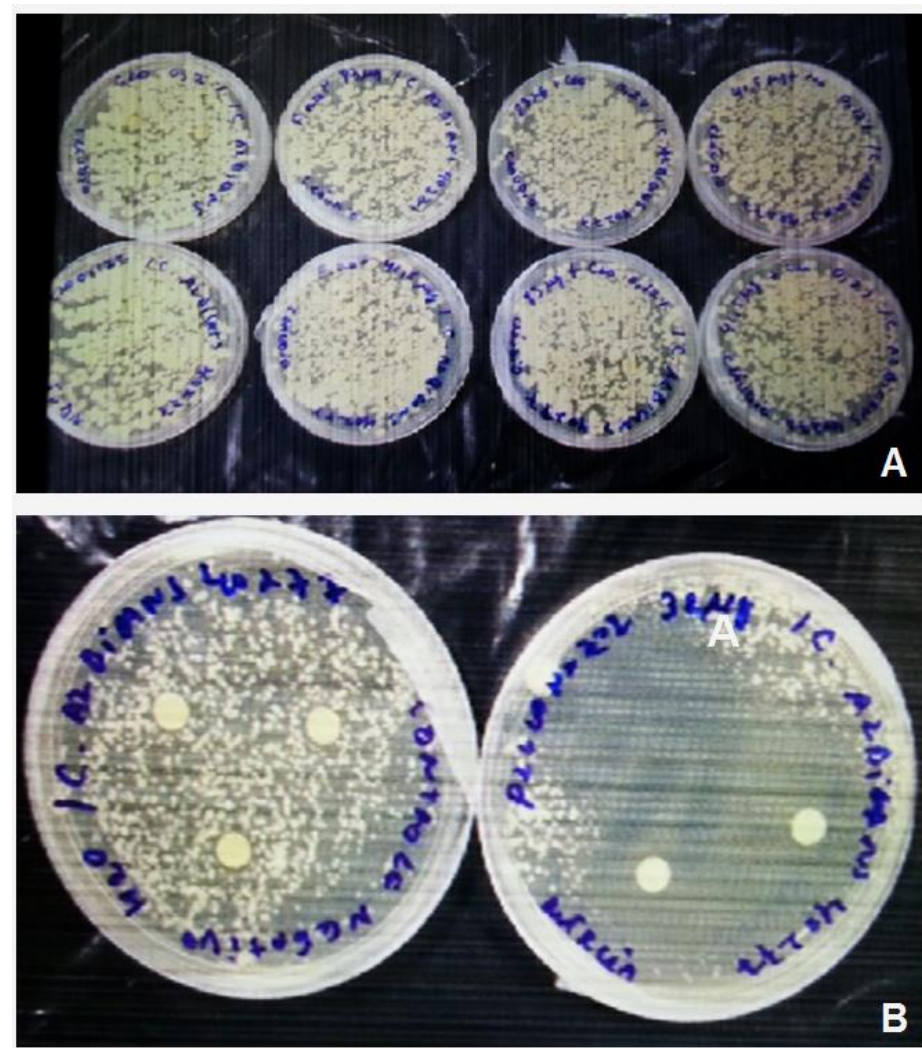

Figura 20. A: Cepas de Candida albicans 40277 não foram sensíveis ao digluconato de clorexidina a 0,2 e $0,12 \%$ ou em combinação com a FAED pelo método de difusão em disco. B: Controle negativo e positivo fluconazol. 
Para o método de microdiluição, a junção do digluconato de clorexidina com o derivado vegetal não demonstrou eficiência na sensibilização deste microrganismo. Já no estudo em relação ao digluconato de clorexidina sozinho este apresentou-se como agente efetivo contra o microrganismo testado, com CIM de 0,0008\% (Figura 21). O estudo da efetividade de sensibilização mostrou que o digluconato de clorexidina ocasionou inviabilidade do microrganismo avaliado, porém a combinação com FAED não foi efetiva tanto qualitativamente quanto quantitativamente.

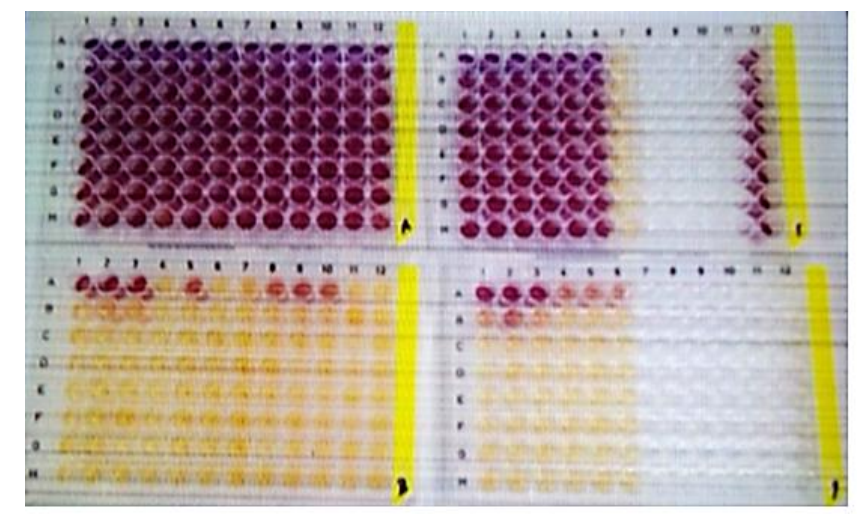

Figura 21. Concentração inibitória mínima do digluconato de clorexidina 0,2 e $0,12 \%$ sozinho ou em combinação contra Candida albicans 40277 pelo método de microdiluição.

O controle positivo fluconazol apresentou concentração inibitória mínima de $3,12 \mu \mathrm{g} / \mathrm{mL}$, ou seja, mostrou atividade antifúngica (Figura 22).

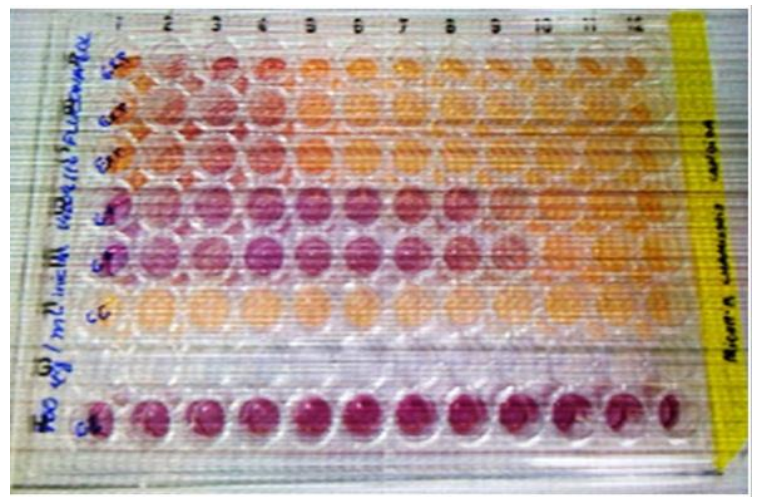

Figura 22. Concentração inibitória mínima do fluconazol para Candida albicans. 


\section{DISCUSSÃo}

A pesquisa por novos biofármacos na área da Odontologia, utilizando extratos de plantas, tem sido realizada devido às dificuldades encontradas em técnicas hoje utilizadas. Conhecer a ação terapêutica desses extratos é de suma importância no campo molecular, farmacêutico e de engenharia tecidual para o desenvolvimento futuro de novos biofármacos que facilitem a reconstrução de estruturas dentárias perdidas. O uso de plantas tem mostrado a possibilidade de reparo tecidual reforçando a importância de novos alvos a serem investigados (15).

Plantas e fitoterápicos são utilizados para o controle de microrganismos, como bactérias e fungos, que afetam a estrutura gengival e periodontal (95). A doença periodontal, como um processo infeccioso, inicia-se com a implantação de microrganismos orais no sulco gengival e, a partir disso, provocam um processo inflamatório, que causa a lesão aos tecidos de suporte dentários (40). Nesse contexto, estudos sobre a ação terapêutica e eficácia de plantas frente a microrganismos, mostram-se importantes para o acesso à população e, assim, resultam no favorecimento da prevenção e tratamento para doenças orais.

Uma das formas de controle e adjunto ao tratamento de doenças periodontais é o uso de enxaguatórios bucais amplamente comercializados. Dentre os vários tipos de enxaguatórios se destaca a utilização do digluconato de clorexidina (96). Estudos demonstram que a solução diminui significantemente o biofilme e, consequentemente, a gengivite. Porém, é conhecido o aumento significativo de pigmentação da solução sobre os dentes e alteração no paladar, devido à interação com as papilas gustativas $(96,97)$. Estudos in vitro revelam a possível ação citotóxica do digluconato de clorexidina sobre a membrana plasmática, causando rompimento da mesma conforme as concentrações utilizadas (98). No Japão não é permitido o uso do digluconato de clorexidina nas concentrações utilizadas em bochechos, devido à incidência de choque anafilático em indivíduos ao contato com a substância (99). Em contrapartida, soluções de bochecho com produtos naturais e 
derivados de plantas têm se mostrado um agente promissor para a prevenção de doenças causadas por acúmulo de biofilme, apresentando atividades antimicrobianas em vários patógenos (100). Constatamos em nossos estudos o efeito citotóxico de solução de digluconato de clorexidina nas concentrações de $0,12 \%$ e $0,2 \%$ em células de mucosa gengival. A FAED apresentou-se menos citotóxica quando comparada ao digluconato de clorexidina. É relevante o estudo de biofármacos que não causam lesões às células quando usados para controle da higiene oral. Visto que o digluconato de clorexidina apresenta efeitos citotóxicos e inibitórios para fibroblastos gengivais e de ligamento periodontal, a Eugenia dysenterica poderia ser proposta como um componente para enxaguatório bucal $(101,102)$. Além disso, ao associarmos o digluconato de clorexidina com o extrato, observou-se baixa citotoxicidade às células gengivais, o que leva a sugerir que a diminuição da morte celular se dá pelo efeito antioxidante do extrato de Eugenia dysenterica, visto que o digluconato de clorexidina libera radicais livres ao se decompor, devido à sua estrutura molecular e níveis elevados de $\mathrm{pH}$ (103).

Uma informação relevante quanto à ação da FAED em bochechos é a ação antibacteriana. Estudos com plantas vêm sendo realizados e observados seus efeitos antimicrobianos na cavidade oral. Rodanant e colaboradores, 2015 (55), relataram o potencial antimicrobiano de Murraya paniculata em Porphyromonas gingivalis e propriedades anti-inflamatórias estimuladas por lipopolissacarídeos. Ocheng e colaboradores, 2015 (104), analisaram dez diferentes plantas originadas da Uganda e seus efeitos sobre Porphyromonas gingivalis, Aggregatibacter actinomycetemcomitans, Streptococcus mutans e Lactobacillus acidophilus. As plantas mostraram-se inibidoras do crescimento das bactérias que causam doenças no periodonto. Silva 2014 (105) em seu estudo avaliou os efeitos antimicrobianos de diversos extratos e frações da Eugenia dysenterica. A fração acetônica do extrato de Eugenia dysenterica na concentração de $83 \mu \mathrm{g} / \mathrm{mL}$ demonstrou ação nas bactérias Gram-positivas, revelando modulação de agentes $\beta$-lactâmicos. Porém, em seu estudo não demonstrou a ação nas bactérias Pseudomonas aeruginosa e Escherichia coli, ou seja, não apresentou ação nessas bactérias Gram-negativas. Tais bactérias, embora não sejam responsáveis pela doença periodontal, são microrganismos encontrados na cavidade oral e que poderiam ser diminuídas caso a Eugenia dysenterica tivesse potencial antimicrobiano para Gram-negativas. Por esse 
motivo, os resultados não demonstraram que a utilização da FAED seja eficaz em soluções como agente antibacteriano Gram-negativos da cavidade oral.

$\mathrm{Na}$ literatura, estudos recentes têm demonstrado a tentativa de utilizar produtos naturais com atividade antifúngica $(106,107)$, o que também já foi descrito por Costa e colaboradores, 2000 (32), utilizando o extrato essencial de óleo das folhas de Eugenia dysenterica. Em seu estudo, há relato da planta ser rica em sesquirtepenos e monoterpenos, produzindo assim um efeito antifúngico no Cryptococcus neoformans, que acomete pacientes imunossuprimidos pelo vírus HIV, acometendo pele e mucosas (108), e também envolvendo os tecidos da cavidade oral (109-111). Por essa razão, é importante uma nova abordagem de tratamento de pacientes com doenças infecciosas, sejam elas raras ou comuns. Pensando nisso, nosso trabalho avaliou a ação antifúngica do extrato de Eugenia dysenterica em Candida albicans. Esse fungo frequentemente torna-se patogênico em pacientes idosos e imunossuprimidos, ou que fazem uso de próteses (112). Conforme relatado nos nossos resultados, observamos que a FAED não produziu efeitos na Candida albicans nas concentrações estabelecidas para ser utilizadas em tecidos bucais. Nas concentrações de $41,5 \mu \mathrm{g} / \mathrm{mL}$, utilizado para a gengiva, e de $83 \mu \mathrm{g} / \mathrm{mL}$, para ligamento periodontal, a FAED não resultou em diminuição do fungo nem mesmo potencialização, quando associada ao digluconato de clorexidina à 0,12 e 0,2\%. Portanto, nossos resultados não apresentam ação da FAED em Candida albicans, assim como também não podemos sugerir que seria uma planta de escolha como um biofármaco para compor um enxaguatório bucal. Entretanto sugerimos que a FAED na concentração de $41,5 \mu \mathrm{g} / \mathrm{mL}$ tenha tido um efeito antioxidante e uma toxicidade menor do que o grupo controle do digluconato de clorexidina, que é disponível atualmente no mercado.

Existem metodologias diversas para avaliar o efeito de drogas no processo de cicatrização de feridas, como por exemplo a câmara de Boyden, os sistemas de dispositivos microfuídos (86), e o Scratch (teste de fechamento de ferida), o qual foi utilizado em nossa pesquisa. Em estudo recente, Yoshikawa e colaboradores, 2016 (113), relataram os efeitos in vitro de óleos essenciais que não apresentaram efeito inibitório na proliferação celular de epitélio gengival. Schmidt e colaboradores, 2009 (114), observaram uma maior atividade de plantas brasileiras (Waltheria douradinha, 
Schinus molle, Galinsoga parviflora) em preencher a área lesionada por scratch. Em um estudo com células imunológicas. Chang e colaboradores, 2014 (115) observaram que a planta Areca nut utilizada não favoreceu a migração e adesão celular, o que pode aumentar a susceptibilidade do hospedeiro à periodontite. Em nosso estudo foi utilizado esse ensaio que avaliou o efeito de Eugenia dysenterica em linhagens celulares de mucosa gengival. No entanto, não se observou 0 fechamento das feridas nas populações quando tratadas com a FAED, resultando num efeito inibitório da migração celular.

A doença periodontal tem como característica histopatológica a reabsorção de osso alveolar e a inflamação dos tecidos periodontais (116). A manutenção do tecido ósseo depende do equilíbrio entre os processos de formação pelos osteoblastos e de reabsorção pelos osteoclastos (117). O desequilíbrio entre esses processos leva à diminuição da estrutura óssea alveolar e à perda dentária. Nos últimos anos, variados tipos de plantas e seus componentes têm recebido atenção especial para sua utilização no tratamento periodontal, com o intuito de se criar novas estruturas de sustentação perdida com a doença periodontal $(64,118-124)$. Vários estudos evidenciaram os efeitos de plantas na viabilidade celular e regulação da expressão de proteínas envolvidas na diferenciação osteogênica, que comprovam a formação de matriz mineralizada por células do ligamento periodontal (15).

As células isoladas a partir do ligamento periodontal produzem colágeno tipo I, fosfatase alcalina, proteínas morfogenéticas ósseas e nódulos minerais quando cultivadas em meio contendo ácido ascórbico, dexametasona e $\beta$-glicerofosfato. ácido ascórbico facilita a diferenciação osteogênica por aumentar a secreção do colágeno tipo I. A dexametasona induz e regula a expressão de RUNX2, que é um fator de transcrição associado à diferenciação de osteoblastos. E o $\beta$-glicerofosfato é uma fonte de fosfato para a mineralização óssea e também induz a expressão de vários genes, como a OPN (Osteopontina) e BMP2 (proteína morfogenética óssea 2) (125). Kim e colaboradores, 2015 (122), revelaram o potencial de deposito de mineral de Zanthoxylum schinifolium em células do ligamento periodontal utilizando o método de coloração de vermelho de Alizarina S. (118), utilizando Morinda citrifolia, também relataram potencial de mineralização de células do ligamento periodontal. Além disso, Chantarawaratit e colaboradores, 2014 (119), e Gao e 
colaboradores, 2013 (120), utilizando Aloe vera e Fructus cnidii, respectivamente, também relataram depósito de mineral por células do ligamento periodontal, demonstraram em estudo in vivo animal a indução de formação óssea. Porém, em nosso estudo, ao averiguar o potencial osteogênico da Eugenia dysenterica deparou-se com a não formação de depósito de mineral, mas sim visualizou-se a inibição da diferenciação osteogênica quando as células foram tratadas com o extrato.

Em recente estudo, Clementino e colaboradores, 2016 (33), confirmaram a presença de polifenóis em extrato de Eugenia dysenterica pela cromatografia e métodos fitoquímicos, e determinou que os compostos fenólicos dão ao extrato o comportamento de atividade antioxidante. Cecilio e colaboradores, 2012 (75), avaliaram a presença de taninos, flavonoides, terpenos e saponinas no extrato etanólico de folhas da Eugenia dysenterica. Couto e colaboradores, 2009 (126), em análise de folhas, encontrou uma elevada taxa de taninos $(53,7 \%)$ e flavonoides $(3,45 \%)$, ao estudar os componentes fenólicos totais. Em nosso estudo foi utilizado a fração acetônica do extrato, que, segundo Rocha e colaboradores, 2011 (127), apresenta a maior eficiência para os compostos fenólicos totais. Nossos resultados divergiram quanto à ação já observada dos polifenóis de outras plantas. Como visto, a Eugenia dysenterica não apresentou efeito antifúngico nas cepas de Candida albicans utilizadas e também não demonstrou potencial de mineralização por células do ligamento periodontal.

Uma ação observada pela FAED foi o potencial antioxidativo do extrato quando adicionada à solução de digluconato de clorexidina. $O$ resultado do nosso trabalho, mostrou uma diminuição de morte celular quando acrescentado o extrato, sugerindo que agiu como um citoprotetor. A possível ação do sequestro de radicais livres liberados pelo digluconato de clorexidina, pode ter sido acometido pela presença de taninos na fração acetônica (62). Em estudo com camundongos, foi avaliado a capacidade protetora da Eugenia dysenterica na mucosa gástrica. Quando os taninos eram removidos da solução, havia uma perda da ação citoprotetora do extrato, indicando que esse composto é responsável pela atividade (31). 
Finalmente, os resultados sugerem que a fração acetônica do extrato de Eugenia dysenterica não respondeu positivamente aos ensaios testados em células de mucosa gengival e de ligamento periodontal, relatados aqui pela primeira vez. No entanto, é preciso considerar as alterações induzidas nas células e seu possível potencial antioxidante, além das ações relatadas pela literatura. Mais estudos devem ser realizados utilizando, inclusive, outras partes da planta, como frutos e flores, a fim de avaliar o potencial do extrato de Eugenia dysenterica em tecidos humanos. 


\section{CONCLUSÃO}

Frente aos objetivos propostos, podemos concluir que:

1. Foi possível o estabelecimento de cultura primária de tecidos de mucosa gengival e ligamento periodontal humanos, tanto pela técnica de explant como por digestão enzimática, respectivamente.

2. A fração acetônica do extrato de Eugenia dysenterica (FAED) não apresentou citotoxicidade em células de mucosa gengival nas 24, 48 e 72 horas após tratamento com as concentrações testadas.

3. A FAED apresentou citotoxicidade apenas na concentração de 83 $\mu \mathrm{g} / \mathrm{mL}$ nas células de ligamento periodontal em 24 horas.

4. Em 24 horas a associação da FAED com o digluconato de clorexidina 0,12\% e 0,2\% não foi citotóxica para as células de mucosa gengival. Em 48 horas a associação da FAED com o digluconato de clorexidina $0,12 \%$ também não foi citotóxica para as células de mucosa gengival, sugerindo a ação antioxidativa.

5. As células de mucosa gengival e ligamento periodontal sofreram alterações morfológicas pós-tratamento com a FAED nas concentrações testadas.

6. A FAED inibiu a ação de proliferação e motilidade de células de mucosa gengival na concentração de $41,5 \mu \mathrm{g} / \mathrm{mL}$.

7. A FAED não apresentou efeitos na diferenciação e formação de matriz mineralizada por células do ligamento periodontal.

8. A FAED não apresentou efeito antimicrobiano combinado ou não com o digluconato de clorexidina. 


\section{REFERENCIAS *}

1. Klayman DL. Qinghaosu (artemisinin): an antimalarial drug from China. Science. 1985;228(4703):1049-55.

2. $\mathrm{Li} Y, W u \mathrm{YL}$. An over four millennium story behind qinghaosu (artemisinin) - a fantastic antimalarial drug from a traditional chinese herb. Curr Med Chem. 2003;10(21):2197-230.

3. Bhattaram VA, Graefe U, Kohlert C, Veit M, Derendorf H. Pharmacokinetics and bioavailability of herbal medicinal products. Phytomedicine. 2002;9 Suppl 3:1-33.

4. de Rezende HA, MonteiroCocco MI. Every day use of phytotherapy in a rural population. Rev Esc Enferm USP. 2002;36(3):282-8.

5. Steele ML, Axtner J, Happe A, Kroz M, Matthes H, Schad F. Adverse Drug Reactions and Expected Effects to Therapy with Subcutaneous Mistletoe Extracts (Viscum album L.) in Cancer Patients. Evid Based Complement Alternat Med. $2014 ; 2014: 1-12$.

6. Brindha P DN. Herbal nutraceuticals in the management of cancer and chronic diseases-a select study. International Journal of Pharmacy \& Pharmaceutical Sciences, Supplement 1e. 2014;6(1):104-6.

7. Pal SK FS. Cancr Treatment with the Alternative Herbal Medicine HUMA: Two Case Reports. Middle East Journal of Cancer. 2014;5(1):41-6.

8. Howes MJ, Houghton PJ. Ethnobotanical treatment strategies against Alzheimer's disease. Curr Alzheimer Res. 2012;9(1):67-85.

9. Chen HY, Ma CH, Cao KJ, Chung-Man Ho J, Ziea E, Wong VT, et al. A systematic review and meta-analysis of herbal medicine on chronic obstructive pulmonary diseases. Evid Based Complement Alternat Med. 2014;2014:1-11.

\footnotetext{
*Referências elaboradas conforme estilo de Vancouver.
} 
10. Tradtrantip L, Ko EA, Verkman AS. Antidiarrheal efficacy and cellular mechanisms of a Thai herbal remedy. PLoS Negl Trop Dis. 2014;8(2):e2674.

11. Pimenta LP, Garcia GM, Goncalves SG, Dionisio BL, Braga EM, Mosqueira VC. In vivo antimalarial efficacy of acetogenins, alkaloids and flavonoids enriched fractions from Annona crassiflora Mart. Nat Prod Res. 2014;28(16):1254-9.

12. Gavanji S LB, Bakhtari A. The effect of extract of Punica granatum var. pleniflora for treatment of minor recurrent aphthous stomatitis. Integr Med Res. $2014 ; 3(2): 93-0$.

13. Agrawal N GR, Gupta I, et al. Herbcraft: boon to the periodontal therapy. Int J Dent Health Sci. 2014;01(01):47-62.

14. Gupta S, Jawanda MK, Arora V, Mehta N, Yadav V. Role of Lycopene in Preventing Oral Diseases as a Nonsurgical Aid of Treatment. Int J Prev Med. 2015;6:70.

15. Costa CRR, Amorim BR, de Magalhaes P, De Luca Canto G, Acevedo AC, Guerra EN. Effects of Plants on Osteogenic Differentiation and Mineralization of Periodontal Ligament Cells: A Systematic Review. Phytother Res. 2016;30(4):51931.

16. Souza C, Felfili J. Uso de plantas medicinais na região de Alto Paraíso de Goiás, GO, Brasil. Acta Bot Bras. 2006;20(1):135-42.

17. Santos F, Carvalho N. Alcoholic Tincture of Garlic (Allium sativum) on Gastrointestinal Endoparasites of Sheep - Short Communication. Ciência Animal Brasileira. 2014;15(1):115.

18. Nicoletti M, Oliveira-Junior M, Bertasso C, Caporossi P, Tavares A. Principais Interações no uso de Medicamentos Fitoterápicos. Infarma. 2007;19(1 e 2):32-40.

19. Myers N, Mittermeier RA, Mittermeier CG, da Fonseca GA, Kent J. Biodiversity hotspots for conservation priorities. Nature. 2000;403(6772):853-8. 
20. Elias ST, Borges GA, Amorim DA, Rego DF, Simeoni LA, Silveira D, et al. Radiation induced a supra-additive cytotoxic effect in head and neck carcinoma cell lines when combined with plant extracts from Brazilian Cerrado biome. Clin Oral Investig. 2015;19(3):637-46.

21. Elias ST, Salles PM, de Paula JE, Simeoni LA, Silveira D, Guerra EN, et al. Cytotoxic effect of Pouteria torta leaf extracts on human oral and breast carcinomas cell lines. J Cancer Res Ther. 2013;9(4):601-6.

22. Souza PM, Elias ST, Simeoni LA, de Paula JE, Gomes SM, Guerra EN, et al. Plants from Brazilian Cerrado with potent tyrosinase inhibitory activity. PLoS One. 2012;7(11):e48589.

23. Silva R, Chaves L, Naves R. Caracterização de Frutos e Árvores de Cagaita (Eugenia dysenterica DC.) no sudeste do Estado de Goiás, Brasil. Rev Bras Frutic, Jaboticabal - SP. 2001;23(2):330-4.

24. Vieira R, Agostini-Costa T, Silva D, Sano S, Ferreira F. Frutas nativas da região Centro-Oeste. Embrapa Informação Técnica. 2010.

25. Oliveira MES, Pantoja L, Duarte WF, Collela CF, Valarelli LT, Schwan RF, et al. Fruit wine produced from cagaita (Eugenia dysenterica DC) by both free and immobilised yeast cell fermentation. Food Research International. 2011;44(7):2391400.

26. Almeida LF, Paula JF, Almeida RV, Williams DW, Hebling J, Cavalcanti YW. Efficacy of citronella and cinnamon essential oils on Candida albicans biofilms. Acta Odontol Scand. 2016:1-6.

27. Tozin LR, Marques MO, Rodrigues TM. Glandular trichome density and essential oil composition in leaves and inflorescences of Lippia origanoides Kunth (Verbenaceae) in the Brazilian Cerrado. An Acad Bras Cienc. 2015;87(2):943-53.

28. Ribeiro TG, Nascimento AM, Henriques BO, Chavez-Fumagalli MA, Franca JR, Duarte MC, et al. Antileishmanial activity of standardized fractions of 
Stryphnodendron obovatum (Barbatimao) extract and constituent compounds. J Ethnopharmacol. 2015;165:238-42.

29. Duarte MC, Tavares GS, Valadares DG, Lage DP, Ribeiro TG, Lage LM, et al. Antileishmanial activity and mechanism of action from a purified fraction of Zingiber officinalis Roscoe against Leishmania amazonensis. Exp Parasitol. 2016;166:21-8.

30. Borges G, FERREIRA J, ELIAS S, ENS G, SILVEIRA D, SIMEONI L. Cytotoxic effect of Plectranthus neochilus extracts in Head and Neck Carcinoma cell lines. African Journal of Pharmacy and Pharmacology. 2016;10:157-63.

31. Prado LC, Silva DB, de Oliveira-Silva GL, Hiraki KR, Canabrava HA, Bispo-daSilva LB. The gastroprotective effects of Eugenia dysenterica (Myrtaceae) leaf extract: the possible role of condensed tannins. Biol Pharm Bull. 2014;37(5):722-30.

32. Costa TR, Fernandes OF, Santos SC, Oliveira CM, Liao LM, Ferri PH, et al. Antifungal activity of volatile constituents of Eugenia dysenterica leaf oil. J Ethnopharmacol. 2000;72(1-2):111-7.

33. Clementino SE, Garcia RS, Moreira BR, Pagliarini BA, Cabral RB, Damaris S, et al. Voltammetric and spectrophotometric determination of antioxidant activity of Eugenia dysenterica DC leaves extracts. Pak J Pharm Sci. 2016;29(2):535-40.

34. LINDHD J, LANG N, KARRING T. Tratado de periodontologia clínica e implantologia oral. $5^{\circ}$ ed. ed. Rio de Janeiro: Guanabara Koogan; 2010.

35. Nanci A. Ten Cate, Histologia Oral. Rio de Janeiro: Elsevier; 2013.

36. Newman MG, Takei H, Klokkevold PR, Carranza FA. Periodontia Clínica. Edição, editor. Rio de Janeiro: Elsevier; 2012.

37. McCulloch CA, Nemeth E, Lowenberg B, Melcher AH. Paravascular cells in endosteal spaces of alveolar bone contribute to periodontal ligament cell populations. Anat Rec. 1987;219(3):233-42.

38. Bartold PM, Gronthos S, Ivanovski S, Fisher A, Hutmacher DW. Tissue engineered periodontal products. J Periodontal Res. 2016;51(1):1-15. 
39. Grzesik WJ, Narayanan AS. Cementum and periodontal wound healing and regeneration. Crit Rev Oral Biol Med. 2002;13(6):474-84.

40. Pihlstrom BL, Michalowicz BS, Johnson NW. Periodontal diseases. The Lancet. 2005;366(9499):1809-20.

41. BARTOLD PM, NARAYANAN AS. Periodontal Regeneration. In.: Biology of the periodontal connective tissues. Chicago: Chicago: Quintessence; 1998.

42. Hagi TT, Laugisch O, Ivanovic A, Sculean A. Regenerative periodontal therapy. Quintessence Int. 2014;45(3):185-92.

43. Iwata T, Yamato M, Ishikawa I, Ando T, Okano T. Tissue engineering in periodontal tissue. Anat Rec (Hoboken). 2014;297(1):16-25.

44. Walker CB, Karpinia K, Baehni P. Chemotherapeutics: antibiotics and other antimicrobials. Periodontol 2000. 2004;36:146-65.

45. Pejcic A, Kojovic D, Mirkovic D, Minic I. Stem Cells for Periodontal Regeneration. Balkan Journal of Medical Genetics : BJMG. 2013;16(1):7-12.

46. Chen FM, Zhang J, Zhang M, An Y, Chen F, Wu ZF. A review on endogenous regenerative technology in periodontal regenerative medicine. Biomaterials. 2010;31(31):7892-927.

47. BRASIL. 1a Conferência Nacional de Medicamentos e Assistência Farmacêutica. Relatório Final Preliminar; Brasília: Ministério da Saúde; 2005.

48. CFO. Fórum sobre as Práticas Integrativas e Complementares à Saúde Bucal. Brasília: Conselho Federal de Odontologia; 2008.

49. Li Y, Li X, Tip P, Zhang L. Use of a novel herbal medicine in a 75-year-old woman with multi-metastatic pancreatic cancer: A case report and review of the literature. Oncology Letters. 2015;10(1):263-7.

50. Ling W, Li Y, Jiang W, Sui Y, Zhao HL. Common Mechanism of Pathogenesis in Gastrointestinal Diseases Implied by Consistent Efficacy of Single Chinese 
Medicine Formula: A PRISMA-Compliant Systematic Review and Meta-Analysis. Medicine (Baltimore). 2015;94(27):e1111.

51. Nabavi SM, Marchese A, Izadi M, Curti V, Daglia M, Nabavi SF. Plants belonging to the genus Thymus as antibacterial agents: from farm to pharmacy. Food Chem. 2015;173:339-47.

52. Chen H, Poon J, Poon SK, Cui L, Fan K, Sze D. Ensemble learning for prediction of the bioactivity capacity of herbal medicines from chromatographic fingerprints. BMC Bioinformatics. 2015;16 Suppl 12:S4.

53. Corega C, Vaida L, Festila DG, Rigoni G, Albanese M, D'Agostino A, et al. The benefits of Quercitin for dentistry and maxillofacial surgery: a systematic review. Minerva Stomatol. 2014;[Epub ahead of print].

54. Kato T, Segami N, Sakagami H. Anti-inflammatory Activity of Hangeshashinto in IL-1beta-stimulated Gingival and Periodontal Ligament Fibroblasts. In Vivo. 2016;30(3):257-63.

55. Rodanant $P$, Khetkam $P$, Suksamrarn A, Kuvatanasuchati J. Coumarins and flavonoid from Murraya paniculata (L.) Jack: Antibacterial and anti-inflammation activity. Pak J Pharm Sci. 2015;28(6):1947-51.

56. Lins R, Vasconcelos FHP, Leite RB, Coelho-Soares RS, Barbosa DN. Avaliação clínica de bochechos com extratos de Aroeira (Schinus terebinthifolius) e Camomila (Matricaria recutita L.) sobre a placa bacteriana e a gengivite. Revista Brasileira de Plantas Medicinais. 2013;15(1):112-20.

57. Meckelburg N, Pinto KC, Farah A, lorio NL, Pierro VS, dos Santos KR, et al. Antibacterial effect of coffee: calcium concentration in a culture containing teeth/biofilm exposed to Coffea Canephora aqueous extract. Lett Appl Microbiol. $2014 ; 59(3): 342-7$.

58. Pinho FV, da Cruz LC, Rodrigues NR, Waczuk EP, Souza CE, Coutinho HD, et al. Phytochemical Composition, Antifungal and Antioxidant Activity of Duguetia furfuracea A. St.-Hill. Oxid Med Cell Longev. 2016;2016:1-9. 
59. Jeong SC, Tulasi R, Koyyalamudi SR. Antioxidant Capacities of Hot Water Extracts and Endopolysaccharides of Selected Chinese Medicinal Fruits. Cancers (Basel). 2016;8(3):1-13.

60. Crozier A, Jaganath IB, Clifford MN. Dietary phenolics: chemistry, bioavailability and effects on health. Nat Prod Rep. 2009;26(8):1001-43.

61. Chung KT, Wong TY, Wei Cl, Huang YW, Lin Y. Tannins and human health: a review. Crit Rev Food Sci Nutr. 1998;38(6):421-64.

62. Sieniawska E. Activities of Tannins - From in vitro studies to clinical trials. Nat Prod Commun. 2015;10(11):1877-84.

63. Yan XT, Li W, Sun YN, Yang SY, Lee SH, Chen JB, et al. Identification and biological evaluation of flavonoids from the fruits of Prunus mume. Bioorg Med Chem Lett. $2014 ; 24(5): 1397-402$.

64. Pei Z, Zhang F, Niu Z, Shi S. Effect of icariin on cell proliferation and the expression of bone resorption/formation-related markers in human periodontal ligament cells. Molecular Medicine Reports. 2013;8(5):1499-504.

65. Almeida S, Proença C, Sano S, Ribeiro J. Cerrado: espécies vegetais úteis. EMBRAPA, editor Planaltina: Empresa Brasileira de Pesquisa Agropecuária, Centro de Pesquisa Agropecuária dos Cerrados; Ministério da Agricultura e do Abastecimento. 1998:464.

66. Almeida S, Silva J, Ribeiro J. Aproveitamento alimentar de espécies nativas dos cerrados: araticum, baru, cagaita e jatobá. EMBRAPA-CPAC, editor PlanaltinaDF : Empresa Brasileira de Pesquisa Agropecuária, Centro de Pesquisa Agropecuária dos Cerrados. 1987:83.

67. Martinotto C, Paiva R, Soares F, Santos B, Nogueira R. Cagaiteira (Eugenia dysenterica DC.). Lavras-MG: Universidade Federal de Lavras. 2008:1 - 21.

68. Santos PRG, Cardoso LdM, Bedetti SdF, Hamacek FR, Moreira AVB, Martino HSD, et al. Cagaita (Eugenia dysenterica DC ) jelly: development, microbiological, 
sensory, chemical characterization, and stability study. Rev Inst Adolfo Lutz. 2012;71(2):281-90.

69. Cardoso LdM, Martino HSD, Moreira AVB, Ribeiro SMR, Pinheiro-Sant'Ana HM. Cagaita (Eugenia dysenterica DC.) of the Cerrado of Minas Gerais, Brazil: Physical and chemical characterization, carotenoids and vitamins. Food Research International. 2011;44(7):2151-4.

70. Camilo Y, Souza E, Vera R, Naves R. Caracterização de frutos e seleção de progênies de cagaiteiras (Eugenia dysenterica DC.). Científica. 2014;42(1):1-10.

71. Roesler R, Malta L, Carrasco L, Holanda R, Sousa C, Pastore G. Atividade antioxidante de frutas do cerrado. Ciênc Tecnol Aliment. 2007;27(1):53-60.

72. Cruz A, Kaplan M. Uso medicinal de espécies das famílias Myrtaceae e Melastomataceae no Brasil. Floresta e Ambiente. 2004;11(1):47-52.

73. Galheigo MR, Prado LC, Mundin AM, Gomes DO, Chang R, Lima AM, et al. Antidiarrhoeic effect of Eugenia dysenterica DC (Myrtaceae) leaf essential oil. Nat Prod Res. 2016;30(10):1182-5.

74. Lima TB, Silva ON, Oliveira JT, Vasconcelos IM, Scalabrin FB, Rocha TL, et al. Identification of $E$. dysenterica laxative peptide: a novel strategy in the treatment of chronic constipation and irritable bowel syndrome. Peptides. 2010;31(8):1426-33.

75. Cecilio AB, de Faria DB, Oliveira Pde C, Caldas S, de Oliveira DA, Sobral ME, et al. Screening of Brazilian medicinal plants for antiviral activity against rotavirus. J Ethnopharmacol. 2012;141(3):975-81.

76. Souza L, Oliveira C, Ferri P, Santos S, Júnior J, Miranda A, et al. Antifungal properties of brazilian Cerrado Plants. Brazilian Journal of Microbiology. 2002;33:247-9.

77. Cole RA, Haber WA, Setzer WN. Chemical composition of essential oils of seven species of Eugenia from Monteverde, Costa Rica. Biochemical Systematics and Ecology. 2007;35(12):877-86. 
78. Goncalves A, Lajolo F, Genovese M. Chemical composition and antioxidant/antidiabetic potential of Brazilian native fruits and commercial frozen pulps. J Agric Food Chem. 2010;58(8):4666-74.

79. Vieira PM, Veronezi E, Silva CR, Chen-Chen L. Detection of genotoxic, cytotoxic, and protective activities of Eugenia dysenterica DC. (Myrtaceae) in mice. J Med Food. 2012;15(6):563-7.

80. Lima $\mathrm{T}$, Silva $\mathrm{O}$, Silva $\mathrm{L}$, Rocha $\mathrm{T}$, Grossi-de-Sá $\mathrm{M}$, Franco $\mathrm{O}$, et al. In vivo effects of Cagaita (Eugenia dysenterica, DC.) Leaf Extracts on Diarrhea Treatment. Evidence-based Complementary and Alternative Medicine. 2011;2011:1-10.

81. Avila RI, Mattos Alvarenga $\mathrm{CB}$, Avila PH, Moreira RC, Arruda AF, Fernandes TO, et al. Eugenia dysenterica DC. (Myrtaceae) exerts chemopreventive effects against hexavalent chromium-induced damage in vitro and in vivo. Pharm Biol. 2016:1-12.

82. Couble ML, Farges JC, Bleicher F, Perrat-Mabillon B, Boudeulle M, Magloire $\mathrm{H}$. Odontoblast differentiation of human dental pulp cells in explant cultures. Calcif Tissue Int. 2000;66(2):129-38.

83. Kedjarune $\mathrm{U}$, Pongprerachok $\mathrm{S}$, Arpornmaeklong P, Ungkusonmongkhon K. Culturing primary human gingival epithelial cells: comparison of two isolation techniques. J Craniomaxillofac Surg. 2001;29(4):224-31.

84. Gronthos S, Brahim J, Li W, Fisher LW, Cherman N, Boyde A, et al. Stem cell properties of human dental pulp stem cells. J Dent Res. 2002;81(8):531-5.

85. Silva SMM. Avaliação da atividade antimicrobiana de espécies vegetais do bioma Cerrado [Dissertação (mestrado)]. Faculdade de Ciências da Saúde: Universidade de Brasília; 2013.

86. Liang CC, Park AY, Guan JL. In vitro scratch assay: a convenient and inexpensive method for analysis of cell migration in vitro. Nat Protoc. 2007;2(2):32933. 
87. Lauffenburger DA, Horwitz AF. Cell migration: a physically integrated molecular process. Cell. 1996;84(3):359-69.

88. Meloan S, Puchtler H. Chemical mechanisms of staining methods: von Kossa's technique. What von Kossa really wrote and a modified reaction for selective demonstration of inorganic phosphate. J Histotechol. 1985;8:11-3.

89. Performance Standards for Antimicrobial Disk Susceptibility Tests; Approved Standard-Eighth Edition. NCCLS document M2-A8 [ISBN 1-56238-485-6]. NCCLS, 940 West Valley Road, Suite 1400, Wayne, Pennsylvania 19087-1898 USA, 2003., (2003).

90. Rossi F, Andreazzi DB. Resistência bacteriana: interpretando o antibiograma. São Paulo: Atheneu; 2005.

91. Eloff J. A sensitive and quick microplate method to determine the minimal inhibitory concentration of plant extracts for bacteria. Planta medica. 1998;64(8):711 3.

92. Zgoda J, Porter J. A convenient microdilution method for screening natural products against bacteria and fungi. Pharmaceutical Biology. 2001;39(3):221-5.

93. Stoppa MA, Casemiro LA, Vinholis AHC, Cunha WR, Silva MLA, Martins CHG, et al. Comparative study of the recommended methodologies by CLSI and EUCAST for activity evaluation antifungal. Química Nova. 2009;32(2):498-502.

94. Cos P, Vlietinck AJ, Berghe DV, Maes L. Anti-infective potential of natural products: How to develop a stronger in vitro 'proof-of-concept'. Journal of Ethnopharmacology. 2006;106:290-302.

95. Oliveira F, Gobira B, Guimarães C, Batista J, Barreto M, Souza M. Espécies vegetais indicadas na odontologia. Revista Brasileira de Farmacognosia. $2007 ; 17(3): 466$.

96. Van Strydonck D, Slot D, Van der Velden U, Van der Weijden F. Effect of a chlorhexidine mouthrinse on plaque, gingival inflammation and staining in gingivitis patients: a systematic review. J Clin Periodontol. 2012;39(11):1042. 
97. Breslin PA, Tharp CD. Reduction of saltiness and bitterness after a chlorhexidine rinse. Chem Senses. 2001;26(2):105-16.

98. Babich H, Wurzburger BJ, Rubin YL, Sinensky MC, Blau L. An in vitro study on the cytotoxicity of chlorhexidine digluconate to human gingival cells. Cell Biol Toxicol. 1995;11(2):79-88.

99. Krautheim AB, Jermann TH, Bircher AJ. Chlorhexidine anaphylaxis: case report and review of the literature. Contact Dermatitis. 2004;50(3):113-6.

100. Freires IA, Denny C, Benso B, de Alencar SM, Rosalen PL. Antibacterial Activity of Essential Oils and Their Isolated Constituents against Cariogenic Bacteria: A Systematic Review. Molecules. 2015;20(4):7329-58.

101. Flemingson, Emmadi P, Ambalavanan N, Ramakrishnan T, Vijayalakshmi R. Effect of three commercial mouth rinses on cultured human gingival fibroblast: an in vitro study. Indian J Dent Res. 2008;19(1):29-35.

102. Cline NV, Layman DL. The effects of chlorhexidine on the attachment and growth of cultured human periodontal cells. Journal of periodontology. 1992;63(7):598-602.

103. IARC. The evaluation of carcinogenic risks to humans. In: Monographs I, editor. IARC Monographs: IARC Monographs; 1997.

104. Ocheng F, Bwanga F, Joloba M, Softrata A, Azeem M, Putsep K, et al. Essential Oils from Ugandan Aromatic Medicinal Plants: Chemical Composition and Growth Inhibitory Effects on Oral Pathogens. Evid Based Complement Alternat Med. 2015;2015:1-10.

105. Silva SMM. Avaliação da atividade antimicrobiana de espécies vegetais do bioma Cerrado. Brasília, DF: Universidade de Brasília; 2014.

106. Pinho FVSA, da Cruz LC, Rodrigues NR, Waczuk EP, Souza CES, Coutinho HDM, et al. Phytochemical Composition, Antifungal and Antioxidant Activity of Duguetia furfuracea A. St.-Hill. Oxidative Medicine and Cellular Longevity. 2016;2016:1-9. 
107. Girardot M, Imbert C. Natural Sources as Innovative Solutions Against Fungal Biofilms. Adv Exp Med Biol. 2016:[Epub ahead of print].

108. Lomes NR, Melhem MS, Szeszs MW, Martins MD, Buccheri R. Cryptococcosis in non-HIV/non-transplant patients: A Brazilian case series. Med Mycol. 2016:[Epub ahead of print].

109. Samaranayake LP. Oral mycoses in HIV infection. Oral Surgery, Oral Medicine, Oral Pathology. 1992;73(2):171-80.

110. de Faria PR, Vargas PA, Saldiva PH, Bohm GM, Mauad T, de Almeida OP. Tongue disease in advanced AIDS. Oral Dis. 2005;11(2):72-80.

111. Tzerbos F, Kabani S, Booth D. Cryptococcosis as an exclusive oral presentation. J Oral Maxillofac Surg. 1992;50(7):759-60.

112. Yarborough A, Cooper L, Duqum I, Mendonca G, McGraw K, Stoner L. Evidence Regarding the Treatment of Denture Stomatitis. J Prosthodont. 2016:[Epub ahead of print].

113. Yoshikawa K, Sekino J, Imamura K, Ota K, Kita D, Saito A. In vitro Effect of Mouthrinse Containing Essential Oils on Proliferation and Migration of Gingival Epithelial Cells. Phytother Res. 2016:[Epub ahead of print].

114. Schmidt C, Fronza M, Goettert M, Geller F, Luik S, Flores EM, et al. Biological studies on Brazilian plants used in wound healing. $J$ Ethnopharmacol. 2009;122(3):523-32.

115. Chang LY, Lai YL, Yu TH, Chen YT, Hung SL. Effects of areca nut extract on lipopolysaccharides-enhanced adhesion and migration of human mononuclear leukocytes. J Periodontol. 2014;85(6):859-67.

116. Garlet GP. Destructive and protective roles of cytokines in periodontitis: a reappraisal from host defense and tissue destruction viewpoints. J Dent Res. 2010;89(12):1349-63. 
117. Goltzman D. Discoveries, drugs and skeletal disorders. Nat Rev Drug Discov. 2002;1(10):784-96.

118. Boonanantanasarn K, Janebodin K, Suppakpatana P, Arayapisit T, Rodsutthi JA, Chunhabundit $\mathrm{P}$, et al. Morinda citrifolia leaves enhance osteogenic differentiation and mineralization of human periodontal ligament cells. Dent Mater J. 2014;33(2):157-65.

119. Chantarawaratit P, Sangvanich P, Banlunara W, Soontornvipart K, Thunyakitpisal P. Acemannan sponges stimulate alveolar bone, cementum and periodontal ligament regeneration in a canine class II furcation defect model. Journal of Periodontal Research. 2014;49(2):164-78.

120. Gao LN, An Y, Lei M, Li B, Yang H, Lu H, et al. The effect of the coumarin-like derivative osthole on the osteogenic properties of human periodontal ligament and jaw bone marrow mesenchymal stem cell sheets. Biomaterials. 2013;34(38):9937-51.

121. Jittapiromsak $N$, Jettanacheawchankit $S$, Lardungdee $P$, Sangvanich $P$, Thunyakitpisal P. Effects of Acemannan on BMP-2 Expression in Primary Pulpal Fibroblasts and Periodontal Fibroblasts, in vivo study $\mathrm{J}$ Oral Tissue Engin. 2007;4(3):149-54.

122. Kim SY, An SY, Lee JS, Heo JS. Zanthoxylum schinifolium enhances the osteogenic potential of periodontal ligament stem cells. In Vitro Cellular \& Developmental Biology-Animal. 2015;51(2):165-73.

123. Kim SY, Lee JY, Park YD, Kang KL, Lee JC, Heo JS. Hesperetin alleviates the inhibitory effects of high glucose on the osteoblastic differentiation of periodontal ligament stem cells. PLoS One. 2013;8(6):e67504.

124. Nowwarote N, Osathanon T, Jitjaturunt P, Manopattanasoontorn S, Pavasant P. Asiaticoside induces type I collagen synthesis and osteogenic differentiation in human periodontal ligament cells. Phytother Res. 2013;27(3):457-62. 
125. Langenbach F, Handschel J. Effects of dexamethasone, ascorbic acid and $\beta$ glycerophosphate on the osteogenic differentiation of stem cells in vitro. Stem Cell Research \& Therapy. 2013;4(5):117.

126. Couto R, Valgas A, Bara M, Paula J. Caracterização físico-química do pó das folhas de Eugenia dysenterica DC. (Myrtaceae). Rev Eletron Farm. 2009;6(3):59-69.

127. Rocha W, Lopes R, Vieira R, Silva J, Agostini--Costa T. Compostos fenólicos totais e taninos condensados em frutas nativas do cerrado. Rev Bras Frutic. 2011;33(4):1215-21. 


\title{
ANEXO A - APROVAÇÃo PELO COMITÊ DE ÉTICA EM PESQUISA, CAAE N 35371514.5.0000.0030
}

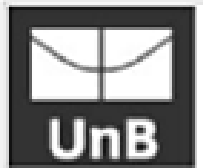

\author{
FACULDADE DE CIÊNCIAS DA \\ SAÚDE DA UNIVERSIDADE DE \\ BRASÍLIA - CEP/FS-UNB
}

\section{PARECER CONSUBSTANCIADO DO CEP}

\section{DADOS DO PROJETO DE PESQUISA}

Título da Pesquisa: Avaliaçào dos efeitos da Eugenia dysenterica em cultura primária de células dos tecidos dentários humanos.

Pesquisador: Cláudio Rodrigues Rezende Costa

Área Temática:

Versão: 5

CAAE: 35371514.5 .0000 .0030

Instituiçāo Proponente: FACULDADE DE SAÚDE - FS

Patrocinador Principal: FUNDACAO UNIVERSIDADE DE BRASILIA

Financiamento Próprio

\section{DADOS DO PARECER}

Número do Parecer: 1.008 .215

Data da Relatoria: 08/04/2015

\section{Apresentaçāo do Projeto:}

"Estudos sugerem o uso de plantas medicinais para a cura, tratamento e prevenção de doenças. Os efeitos de plantas do cerrado veem sendo analisadas e comprovadas sobre patologias existentes, contribuindo para o desenvolvimento de biofármacos e o restabelecimento da saúde. Dentre os diversos frutos do cerrado, a Eugenia dysenterica tem apresentado potencial atividade antifúngica, efeitos antioxidantes e antidiarreicos. atividade inibitória sobre a enzima tirosinase, e um potencial eteito para o tratamento de doenças gástricas. No entanto, os efeitos da Eugenia dysenterica em tecidos dentários humanos ainda nāo foram descritos na literatura. Com a finalidade de melhor utilizaçáo deste fruto do cerrado como um biofármaco, este estudo tem como objetivo avaliar os efeitos da Eugenia dysenterica em cultura primária de células dos tecidos dentários humanos, para, assim, oferecer uma nova abordagem terapêutica segura e eficaz para o tratamento de doenças na odontologia. Para cumprir o objetivo proposto, seräo estabelecidas culturas primárias de polpa, papila apical e ligamento periodontal, obtidas de terceiros molares inclusos e hígidos, e gengiva extraídos por indicaçoes clínicas. Será realizado avaliaçáo da viabilidade celular utilizando o teste de MTT (Ensaio de Atividade Mitocondrial), análise de mortologia celular, teste de cicatrizaçăo (Scratch assay), teste de migraçăo (Transwell Migration Assay), ensaio de diferenciaçao dentinho-osteogẻnica, utilizando coloraçāo vermelho de Alizarina S, expressảo gënica, e por fim a

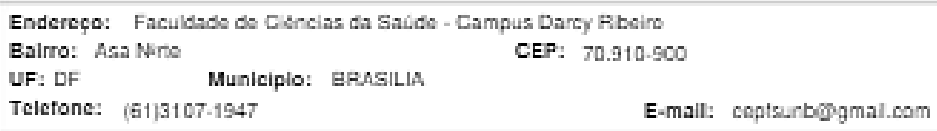




FACULDADE DE CIÊNCIAS DA
SAÚDE DA UNIVERSIDADE DE
BnB
BRASÍLIA - CEP/FS-UNB

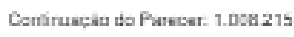

análise estatistica dos dados obtidos. Espera-se que a pesquisa permita uma melhor compreensảo das bases moleculares das estruturas dos tecidos dentários tratados com o extrato de Eugenia dysenterica, no intuito de estabelecer nowos biótármacos para o uso baseado em evidéncias científicas, proporcionando melhora a qualidade de vida com o tratamento odontológico. O projeto está vinculado ao Mestrado no programa de Pós-graduaçao em Ciências da Saúde da Universidade de Brasilia.'

Objetivo da Pesquisa:

"Objetivo Primário:

Avaliar os efeitos da Eugenia dysenterica em cultura primária de células dos tecidos dentários humanos.

Objetivo Secundário:

Estabelecer cultura primária de células pulpares, ligamento periodontal, papila apical de dentes com indicaçáo de exodontia e gengiva; Avaliar a viabilidade celular da cultura primária estabelecida dos tecidos dentários, após tratamento com extrato de Eugenia dysenterica; Analisar a morfologia celular da cultura primária de células dos tecidos dentários após tratamento com extrato de Eugenia dysenterica; Avaliar o potencial de migraça e cicatrizaça de células dos tecidos dentários após tratamento com extrato de Eugenia dysenterica; Investigar o papel do extrato de Eugenia dysenterica na diferenciaçäo odontogênica."

\section{Avaliaçāo dos Riscos e Beneficios:}

Riscos e beneficios, segundo o pesquisador:

"Riscos:

Os riscos da exodontia, realizada com indicação clínica, podem incluir, por exemplo, moléstia transitória,infecçao pós-operatória, sangramento, descontorto e efeitos colaterais de medicamentos prescritos no pós-operatório, porém os benetícios à saúde bucal e geral proporcionados pela exodontia superam os riscos inerentes ao procedimento. N entanto, o projeto de pesquisa envolve apenas as etapas posteriores à extraçao, com a execuçăo de experimentos laboratoriais para caracterizar a cultura primária de células pulpares, gengivais e da papila apical dos dentes doados por meio de assinatura do TCLE e, portanto, năo representa risco direto para os pacientes. Pode haver necessidade de realizaçäo de exames bicquímicos e de imagem.

Benetícios:

Como benefícios,espera-se que a pesquisa permita uma melhor compreensäo das bases moleculares das estruturas dos tecidos dentários tratados com o extrato de Eugenia dysenterica,

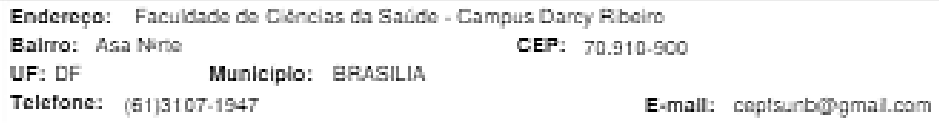




\section{FACULDADE DE CIÊNCIAS DA SAÚDE DA UNIVERSIDADE DE BRASÍLIA - CEP/FS-UNB}

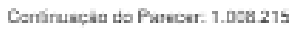

no intuito de estabelecer novos biofármacos para o uso baseado em evidẻncias cientificas, proporcionando melhora na qualidade de vida com o tratamento odontológico."

Comentários e Consideraçōes sobre a Pesquisa:

Projeto de Mestrado do programa de Pós-graduaçào em Ciências da Saúde da Universidade de Brasilia (UnB), orientado pela Prota. Eliete Neves da Silva Guerra do Departamento de Odontologia da UnB.

\section{Consideraçōes sobre os Termos de apresentaçāo obrigatória:}

Documentos apresentados em atendimento as pendéncias apontadas no parecer N*. 990.592 de 18/03/2015:

Informaçoes Básicas do Projeto - "PB_INFORMAÇÓES_BÁSICAS_DO_PROJETO_37050D.pdf", postado em 30/03/2015;

"Carta de Modificaçoes Eugenia dysenterica 4.doc", postado em 30/03/2015;

TCLE - "TCLE Eugenia dysentertica 5.doc", postado em 30/03/2015.

\section{Recomendaçōes:}

Nào se aplica.

Conclusōes ou Pendências e Lista de Inadequaçōes:

Cuanto ao TCLE:

1. Foi realizada revisāo ortográfica e gramatical ao longo do texto do TCLE. PENDENCIA ATENDIDA

2. Foi realizada adequaçào do texto, constando no TCLE apresentado o trecho "Fica também garantida indenizaçao em casos de danos diretos ou indiretos decorrentes da participaçao na pesquisa, contorme decisao judicial ou extra-judicial.". PENDENCIA ATENDIDA

Pendências sanadas.

Protocolo de pesquisa em conformidade com a Resoluçăo CNS 466/2012 e complementares.

Situaçäo do Parecer:

Aprovado

Necessita Apreciaçāo da CONEP:

Nå

\section{Consideraçōes Finais a critério do CEP:}

Em acordo com a Resoluçāo 466/12 CNS, itens X.1.- 3.b. e XI.2.d, os pesquisadores responsáveis deverāo apresentar relatórios parcial semestral e final do projeto de pesquisa, contados a partir da

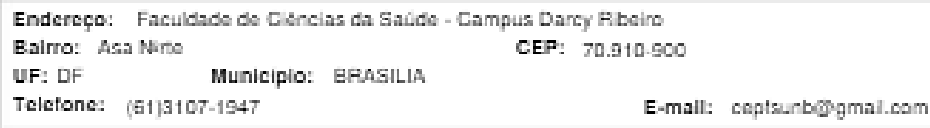


FACULDADE DE CIÊNCIAS DA SAÚDE DA UNIVERSIDADE DE BRASÍLIA - CEP/FS-UNB

UnB

Cenáruaçàu do Punecer. 1.0za.219

data de aprovaçáo do protocolo de pesquisa.

BRASILIA, 01 de Abril de 2015

Assinado por:

Marie Togashi

(Coordenador)

Endereço: Faculdade de Cencias da Saide - Campus Darcy Rboiro

Balrro: Asa Nono CEP: 70.910.900

UF: DF Municipio: BRASILIA

E-mall: copteurbøgmal.com

Plotoforma
Brasil

Telefone: (61)3107-1947 


\title{
APÊNDICE A - TERMO DE CONSENTIMENTO LIVRE E ESCLARECIDO
}

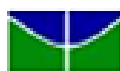 \\ Universidade de Brasília \\ Programa de Pós-Graduação cm Ciências da Saúde
}

TERMO DE CONSENTIMENTO LIVRE E ESCLARECIDO - TCLE

O (A) senhor (a) está sendo convidado (a) a participar da pesquisa "Avaliação dos efeitos da Eugenia dysenterica em cultura primária de células dos tecidos dentários humanos". O objetivo é avaliar os efeitos da Eugenia dysenterica (Cagaita) sobre células da polpa dentária. papila apical, ligamento periodontal e gengiva, obtidas a partir de dentes extraidos por razōes clínicas. Estas células serũo cultivadas e, posterionnente, submetidas a testes com o extrato dessa planta. Com esta pesquisa, espera-se verificar a possibilidade ou não de se utilizar o extrato de Eugenia dysenterica como medicamento.

Ao assinar este termo, o senhor (a) estará autorizando ceder o(s) dente(s) e gengiva (s) com indicação de extração para contribuir com esta pesquisa, consciente de que este(s) dente(s) foi(ram) extraidos por indicação terapêutica, para melhoria da sua suúde, como documentado em seu prontuário.

Somente as células do(s) dente(s) e gengiva(s) serão utilizadas na presente pesquisa. Os fragmentos remanescentes serão descartados. Após conclusão dos experimentos, as células serão armazenadas e, caso sejam utilizadas em uma pesquisa futura, o senhor(a) será contatado para novo consentimento. De acordo com os achados na pesquisa os tecidos poderão ser necessários para procedimentos complementares para experimentos no futuro, por isso há a necessidade de armazenamento (biorrepositório) dos tecidos coletados, para não precisar de uma nova coleta.

O senhor (a) não terá nenhum custo e não receberá nenhuma remuneração ao participar desta pesquisa. Os gastos necessários para a sua participação na pesquisa serũo assumidos pelos pesquisadores. Os riscos com a pesquisa são mínimos ao (a) senhor (a), visto que os experimentos serão realizados em tecidos removidos com indicação terapêutica em laboratório e não haverá nenhum experimento que cause risco direto à sua saúde. Pode haver o risco de quebra de sigilo e confidencialidade dos seus dados, porém a sua identidade será preservada (seu nome não será revelado). Fïca também garantida indenização em casos de danos diretos ou indiretos decorrentes da participaçio na pesquisa, conforme decisīo judicial ou extrajudicial. $O$ (A) senhor (a) pode se recusar ou desistir de participar da pesquisa em qualquer momento, sem qualquer forma de prejuizo. Em qualquer momento, o senhor (a) poderá ter acesso aos resultados e eles poderão ser publicados em eventos e revistas científicas, sempre mantendo o sigilo da sua participaçâo. 
Espera-se, com esse estudo, obter uma melhor compreensão dos eventos que regulam a ação da Eugenia dysenterica em tecidos dentários humanos.

Este projeto está em conformidade com a Resolução CNS 466/2012, e foi aprovado pelo Comitê de Ética em Pesquisa da Faculdade de Ciências da Saúde (CEP/FS) da Universidade de Brasilia. O CEP é composto por profissionais de diferentes áreas cuja função é defender os interesses dos participantes da pesquisa em sua integridade e dignidade e contribuir no desenvolvimento da pesquisa dentro de padrōes éticos. As dúvidas com relação à assinatura do TCLE ou os direitos do participante da pesquisa podem ser obtidas através do telefone: (61) 3107 1947 ou do e-mail cepfs@unb br ou cepfsunb@gmail.com. horírio de atendimento de 10:00hs às 12:00hs e de 13:30hs às 15:30hs, de segunda a sexta-feira.

O (A) senhor (a) tem total liberdade de pedir esclarecimentos em relação a qualquer dúvida que surja. Qualquer dúvida, você poderá entrar em contato com a pesquisador responsável Cláudio Rodrigues Rezende Costa (61) 9148-7278, ou a orientadora responsável Dra. Eliete Neves da Silva Guerra (61) 9668-4988.

Eu,

autorizo ceder meu(s) dente(s) e/ou fragmentos de gengiva para pesquisa "Avaliação dos efeitos da Eugenia dysenterica em cultura primária de células dos tecidos dentários humanos", ciente de que este(s) foi(ram) extraídos por indicação terapêutica, como documentado em meu prontuário. Autorizo a coleta, o depósito, o armazenamento e a utilização do material coletado. Concordo com todos os itens abordados no termo de consentimento livre e esclarecido.

Este documento foi elaborado em duas vias, uma ficará com o pesquisador responsável e a outra com o Senhor(a).

Assinatura do cedente ou responsável

Assinatura do pesquisador responsável

Brasilia,

de de 201 